\title{
Las formas de reparación en la responsabilidad del Estado: hacia su unificación sustancial en todas las acciones
}

contra el Estado*

\section{Juan Carlos Henao ${ }^{* *-* * *}$}

Resumen: Este trabajo comporta un análisis crítico de la reparación del daño en el derecho administrativo colombiano. A partir del estudio de las nociones de 'daño' y 'reparación', esenciales para la atribución de responsabilidad civil, se demuestra el carácter limitado del entendimiento clásico de la responsabilidad extracontractual del Estado. Así pues, el artículo propone una comprensión de la reparación a partir del criterio de 'universalización', con independencia de las acciones por medio de las cuales se persiga una condena del Estado. Además, hace un estudio sobre los medios de control consagrados en el Código de Procedimiento Administrativo y de lo Contencioso Administrativo, y las acciones constitucionales a la luz de las diversas formas de reparación del daño.

Palabras clave: responsabilidad extracontractual del Estado, daño, reparación, formas de reparación, reparación in natura, subrogado pecuniario, medios de control.

* Fecha de recepción: I6 de mayo de 2015. Fecha de aprobación: 27 de mayo de 2015.

Para citar el artículo: J. C. Henao, "Las formas de reparación en la responsabilidad del Estado: hacia su unificación sustancial en todas las acciones contra el Estado", Revista de Derecho Privado, Universidad Externado de Colombia, n. ${ }^{\circ}$ 28, enero-junio de 201 5, pp. 277-366. DOI: I0.1860I/OI 234366.n28. I0

* Rector y Docente Investigador de la Universidad Externado de Colombia; ex Presidente de la Corte Constitucional; Doctor en Derecho de la Universidad París 2 Panthéon-Assas; Doctor Honoris Causa de la Universidad de Montpellier r. Contacto: juan.henao@uexternado.edu.co

*** El autor desea manifestar su agradecimiento a Manuela Canal Silva, abogada recién graduada de la Universidad Externado de Colombia y ya vinculada como profesora en el Departamento de Derecho Administrativo, por su ayuda en la identificación de sentencias que ilustran el presente escrito y por la inteligencia y pertinencia de sus observaciones; así como a Santiago Perea, por su excelente labor como corrector de estilo. 


\title{
Reparation forms on liability of the State: Towards the substantial unification in all the remedies against the State
}

\begin{abstract}
Aвstract: This paper involves a critical analysis of tort reparation in the Colombian administrative law. From the study of the notions of 'damage' and 'reparation', that are the basis of liability, it is shown the limited understanding of extra-contractual liability of the State. Thus, the author proposes an understanding of the reparations based on the 'universalization' criteria, without the consideration of the judicial remedy that pursuit the liability of the State. In addition, the article explores the judicial resources determined by the Código de Procedimiento Administrativo y de lo Contencioso Administrativo and the constitutional remedies, regarding the different forms of tort reparation.
\end{abstract}

KEYwords: Extra-contractual liability of the State, damage, reparation, forms of reparation, reparation in natura, pecuniary compensation, judicial remedies.

Sumario: Introducción. Primera parte. Conceptos necesarios para entender las formas de reparación de daños. A. Concepto de daño. B. Concepto de reparación. Segunda parte. Las diversas formas de reparación de daños. A. Modos de reparación admitidos como tales sin discusión por la doctrina. B. Los medios de reparación discutidos y los novedosos. Conclusión.

\section{Introducción}

I. Planteamiento del tema. El presente escrito busca indagar acerca del alcance del concepto de reparación de daños en el derecho administrativo colombiano. Dos anotaciones previas son necesarias para explicar lo que habrá de desarrollarse en este trabajo: la primera consiste en recordar que es usanza de los libros dedicados al tema limitar su estudio a la jurisprudencia producida a partir de la acción de reparación directa de la Sección Tercera del Consejo de Estado ${ }^{\mathrm{I}}$, sin estudiar la misma problemática en otras secciones de dicha corporación, ni la forma como

I Ver, a título de ejemplo: E. Gil Botero, Tesauro de responsabilidad extracontractual del Estado, Bogotá, Temis, 2013, 3 tomos y 5 volúmenes, con dos tomos adicionales que actualizan hasta el año 20 I 5 los anteriores. Esta es una obra de extrema utilidad para los estudiosos de la materia, en donde se enuncia que "la mayoría de las referencias jurisprudenciales son de providencias de la Sección III del Consejo de Estado” (p. viI), a lo cual yo agregaría -recalcando la inmensa utilidad de la obra- que se trata de una muy grande y extrema mayoría; E. Gil Botero, Responsabilidad extracontractual del Estado, 6. ${ }^{\mathrm{a}}$ ed., Bogotá, Temis, $20 \mathrm{I}$ 3, en cuyo capítulo II se refiere a sentencias tanto de la Sección Tercera del Consejo de Estado como de la Corte Constitucional, pero de esta última corporación solo al estudiar el carácter directo del daño, que para el autor equivale al estudio de la imputación; O. Velásquez Posada, Responsabilidad civil extracontractual, Bogotá, Universidad de la Sabana y Editorial Temis, 2009, especialmente la parte quinta; R. SAAVEdra Becerra, La responsabilidad extracontractual de la Administración pública, Bogotá, Grupo Editorial Ibáñez, 20 I I, en particular el numeral 20 de la tercera parte. 
se presenta en otras acciones procesales; la segunda, que la noción de reparación de daños se ha limitado usualmente a la pecuniaria ${ }^{2}$, sin incluir otras formas de reparación.

Como se verá adelante, ambas posiciones son -en mi entender- equivocadas. Tanto los avances jurisprudenciales recientes -los cuales indican que la acción de reparación directa no está hoy en día limitada a la condena pecuniaria, que en ocasiones no es ni siquiera la más apropiada- como las diversas y múltiples maneras de concebir la reparación que se presenta en varias acciones, y no necesaria y exclusivamente en las contencioso administrativas, muestran que la postura restrictiva de la reparación es insuficiente para ilustrar la realidad de las condenas al Estado en nuestro medio.

De ahí que se proponga la siguiente hipótesis en el presente trabajo: la noción de reparación integral de daños en materia de responsabilidad del Estado es universal al interior de todas las acciones procesales donde este sea condenado, lo cual supone que en ellas se pueden y se deben aplicar de manera uniforme las formas de reparación concebidas por la ley, los tratados internacionales, la doctrina y la jurisprudencia. Esta posición es una invitación a que el análisis de la reparación debida por el Estado no se limite al estudio de la jurisprudencia de la Sección Tercera del Consejo de Estado ni a la indemnización pecuniaria, y a que, por el contrario, se constate que -tímida pero certeramente- todas las secciones de dicha corporación y aun de otras jurisdicciones inician un recorrido que permitirá -ojalá pronto- unificar criterios y reparar de forma similar.

¿Se puede en una acción de nulidad y restablecimiento laboral solicitar como medida de reparación excusas públicas de parte del jefe de una entidad en caso de un acoso laboral cualquiera? ¿Se puede pedir en la anulación de una sanción administrativa que se diga en los medios de comunicación que una sociedad intervenida no incurrió en las prácticas desleales que se le atribuyeron? ¿Se puede pretender en una acción de controversias contractuales que se indemnice el daño moral que sufre el contratista caducado? ¿Se puede solicitar por un grupo minoritario que el Estado presente excusas públicas por discriminaciones históricas? ¿Se puede buscar que antes de la consolidación de un daño consumado el Estado tenga que actuar prontamente para impedir el inicio de su lesión definitiva? Estas y muchas otras preguntas son las que pretende responder este escrito, retomando la hipótesis ya enunciada: la reparación de daños no puede estar marcada por la acción contencioso administrativa, constitucional u ordinaria pertinente, sino que es el daño el que debe determinar las pretensiones que se pueden esgrimir en cualquiera de las acciones judiciales, contencioso administrativas o no,

2 Ver, a nivel de ejemplo, Velásquez Posada, Responsabilidad civil extracontractual, cit., en especial la parte sexta; W. Ruiz Orejuela, Responsabilidad del Estado y sus regímenes, Bogotá, Ecoe Ediciones, 20I0, en particular el cap. II. 
llamadas -en mi entender inoficiosamente- 'medios de control' en la nueva Ley I 437 de 20 I I $^{[3]}$.

2. Presentación del plan. Teniendo en cuenta las precisiones anteriores, el escrito se desarrollará en dos partes: en una primera, se estudiarán los conceptos necesarios para explicar mi concepción de lo que significa reparación de daños. En una segunda parte, se analizarán conceptual y jurisprudencialmente las diversas maneras de reparación que existen en nuestro ordenamiento, en lo que tiene que ver con las condenas al Estado.

\section{Primera parte. \\ Conceptos necesarios para entender las formas de reparación de daños}

3. Daño y formas de reparación. Para entender la noción de reparación de daños se debe recordar un postulado elemental en materia de Responsabilidad Civil: el objetivo de esta última es la reparación de daños, y el alcance de lo que es reparación dependerá de lo que se entienda por daño. Es por ello que veremos en una primera parte la noción de daño (A), para pasar luego a aquella de reparación (B).

\section{A. Concepto de daño}

4. Definición de daño. En la tesis doctoral que sustenté en la Universidad de París 2 Panthéon-Assas definí 'daño' de la siguiente manera: “daño es toda afrenta a los intereses lícitos de una persona, trátese de derechos pecuniarios o de no pecuniarios, de derechos individuales o de colectivos, que se presenta como lesión definitiva de un derecho o como alteración de su goce pacífico y que, gracias a la posibilidad de accionar judicialmente, es objeto de reparación si los otros requisitos de la responsabilidad civil -imputación y fundamento del deber de reparar- se encuentran reunidos"4.

5. Elementos de la definición que impactan sobre la noción de reparación. La definición dada busca superar las falencias anotadas en el parágrafo I del presente escrito. Sin querer explicar la totalidad de la definición, plasmada en I 33 páginas de la tesis doctoral, quiero por ahora resaltar lo siguiente: partiendo de que el daño supone la lesión de un interés lícito o al menos no contrario a derecho,

3 Remito en este sentido a mi escrito, "De tal derecho lesionado, tal acción", en $V$ fornadas de Derecho Constitucional y Derecho Administrativo, Bogotá, Universidad Externado de Colombia, 2005, pp. 486-54I.

4 J. C. Henao, Le dommage. Analyse à partir de la responsabilité civile extracontractuelle de l'État en droit colombien et en droit français, tesis doctoral, Universidad de París 2 Panthéon-Assas, sustentada el 27 de noviembre de 2007 , p. I 33 de la versión traducida al español y que está en proceso de actualización y corrección para convertirse en una nueva edición de mi libro El daño, publicado en el año i998: con esta definición sustituyo aquella dada en dicho año. 
lo importante ahora es observar que dicha lesión se puede presentar tanto sobre intereses pecuniarios como no pecuniarios, lo mismo que sobre intereses colectivos o individuales, sin dejar de lado que la amenaza de lesión definitiva del derecho también es per se daño. Estos tres elementos de la definición tienen incidencia sobre el objeto de nuestro estudio, como pasa a verse.

6. La lesión sobre intereses pecuniarios y sobre intereses no pecuniarios. Esta distinción es fundamental en la medida en que permite sentar una de las grandes summa divisio de la materia, que consiste en diferenciar entre la naturaleza económica y la naturaleza no económica del derecho o interés lesionado, lo cual tiene hondas repercusiones sobre la manera de reparar. Es así como, cuando se lesionan derechos pecuniarios, la reparación es de naturaleza económica, en tanto que la reparación de los derechos no pecuniarios puede revestir formas diferentes de la económica, advirtiendo que cuando se otorga una suma de dinero la misma no equivale al daño sufrido sino a su simple compensación. Y lo anterior debido a que los derechos pecuniarios o materiales tienen valor de cambio en el mercado, lo cual no ocurre con aquellos no pecuniarios o inmateriales. Para citar solo algunos ejemplos, ¿puede valorarse económicamente la honra, la dignidad, la libertad de expresión o la libertad de locomoción? Es evidente que no, lo cual no impide que, gracias a los avances hechos en materia de protección de derechos, su lesión suponga una reparación. Lo anterior porque la existencia del daño implica necesariamente su reparación, para que así la responsabilidad civil no pierda su objeto. Dicha reparación, por mucho que en ocasiones se otorgue en dinero -piénsese en los Ioo SMLV otorgados por daño moral frente a una lesión a la honra-, no supone que dicha suma sea el "valor" del daño, por la sencilla razón de que no tiene un equivalente que permita su medición. En ese sentido, pues, es posible afirmar que la reparación de la lesión de derechos pecuniarios es de mayor facilidad que aquella de los no pecuniarios, donde el juez dispone de un arbitrium iudicis que le permite postular nuevas y creativas maneras de reparar, como se verá posteriormente.

7. La lesión sobre intereses individuales o sobre intereses colectivos. Esta distinción también tiene gran incidencia en la forma como se conciba la reparación, porque es diferente reparar a personas individualmente consideradas -aun jurídicas- que a colectivos que representan intereses difusos no apropiables. Como bien lo enuncia la Corte Constitucional, en un fallo que podríamos calificar de fallo de principio sobre la definición de los diferentes intereses protegidos por el derecho de daños,

... la doctrina comparada habla de que el objeto de las acciones de grupo es proteger "intereses de grupo con objeto divisible", o "intereses plurisubjetivos", o "derechos o intereses subjetivos homogéneos", a diferencia de las acciones populares en las que se protegen intereses de grupo con objeto indivisible o derechos colectivos en sentido estricto: los intereses colectivos y los intereses difusos. Esta distinción 
entre los diversos tipos de intereses jurídicos protegidos por las diversas acciones colectivas permite arrojar claridad sobre el elemento de la titularidad. Y en este aspecto, la primera diferencia importante es aquella que existe entre los intereses colectivos indivisibles, propios de la acción popular, y aquellos divisibles, que son el objeto de las acciones de grupo. Los intereses difusos y colectivos, protegidos por las acciones populares, hacen referencia a derechos o bienes indivisibles, o supraindividuales, que se caracterizan por el hecho de que se proyectan de manera unitaria a toda una colectividad, sin que una persona pueda ser excluida de su goce por otras personas. [...] Algunos ejemplos típicos de esos intereses colectivos o bienes públicos son entonces la defensa nacional, la seguridad pública o la pureza del aire como elemento del medio ambientes.

Si bien esta definición de la Corte Constitucional se hace comparando los derechos que defiende la acción popular con aquellos protegidos por la acción de grupo o de clase, se puede afirmar que la naturaleza de estos últimos es equivalente a la que se protege en cualquier acción donde la petición sea para sí, es decir, de corte individualista, precisamente porque también se trata de intereses divisibles. Tener en cuenta que el daño puede recaer sobre ambos tipos de derechos amplía el espectro de la responsabilidad estatal y genera, como consecuencia inmediata, que el estudio de las formas de reparación de la acción popular tenga que ser incluido en este escrito. Además, permite entender algunas complejidades que puede presentar la reparación de lo colectivo, lo cual también será resaltado posteriormente.

8. La simple amenaza de lesión definitiva del derecho como daño. La tradición doctrinaria en materia de responsabilidad civil plantea que el daño se presenta cuando hay lesión definitiva del derecho ${ }^{6}$. Por el contrario, la postura que plantea mi definición de daño es diferente: el daño existe desde el momento en el cual se altera su goce pacífico, y aun antes de que se inicie la consumación de su lesión. Me apoyo en una frase del profesor De Cupis para sustentar la idea:

5 Corte Constitucional, Sala Plena, 8 de junio de 2004, actor: Manuel Leonidas Palacios Córdoba, exp. D-4939. Se recuerda otra sentencia de importancia para el estudio del concepto: Corte Constitucional, Sala Plena, I4 de abril de r999, demandante: Andrés De Zubiría Samper y otros, exps. acumulados D-2 I 76, D-2 I 78 y D-2 I 96.

6 Ver, por ejemplo: E. Barros Bourie, Tratado de responsabilidad extracontractual, Santiago, Jurídica de Chile, 2008, en especial pp. 874 ss. De igual manera, ver: J. González Pérez, Responsabilidad patrimonial de las administraciones públicas, Madrid, Civitas, I996, p. 229: "para la viabilidad de la pretensión indemnizatoria, es necesario que el daño ocasionado sea real, es decir, efectivo y patrimonialmente evaluable. Es requisito de la viabilidad de la pretensión la 'efectiva realidad del daño o perjuicio"'. Sin embargo, en el párrafo inmediatamente anterior afirma: "Por daño efectivo -dice Leguina- hay que entender el daño cierto, ya producido, no simplemente posible o contingente, lo que no excluye que, en algún caso, deba indemnizarse también el daño que habrá de ocurrir en el porvenir pero cuya producción sea indudable y necesaria por la anticipada certeza de su acaecimiento en el tiempo". 
Y tampoco puede aducirse, en sentido contrario, que el acto ilícito (antijurídico) puede producir en vez de un daño, un simple peligro de daño. Porque en verdad también el peligro de daño incide negativamente en el valor del bien al que incumbe, disminuyendo tal valor y repercute en el interés del sujeto a quien corresponde el bien; es ya de por sí, un daño, prescindiendo de aquel daño que podrá derivar de la actuación de la virtual posibilidad ínsita en él. Aunque el peligro desaparezca con la pretendida agresión del bien ajeno, sin embargo, se ha producido una disminución lo breve y limitada que se quiera, de la seguridad de goce del mismo bien, un perjuicio, consiguiente, para el titular de éste7.

Es decir, la tesis tradicional al abordar el estudio del daño supone que la responsabilidad civil opera desde el momento en que ya inició la lesión definitiva del derecho -así no haya cesado-, pero no estudia la hipótesis resaltada por DE Cupis, esto es, aquella en la cual no se ha iniciado dicha lesión definitiva por encontrarse en ciernes. La postura aquí defendida supone que hay tres etapas del daño cierto: la primera va desde el momento en el que inicia la perturbación o alteración del goce pacífico del derecho o interés, sin que aún se haya iniciado la lesión definitiva; la segunda va desde el momento en el que inicia la lesión definitiva del derecho y sigue presentándose, lo cual se define en doctrina como daño continuado, y la tercera supone que el derecho ya fue lesionado definitiva y totalmente. Desde esta perspectiva, el no daño lo constituye el goce pacífico del derecho.

Con independencia de que dicha concepción de daño sea aceptada, lo que interesa resaltar para este escrito es que los sistemas jurídicos tienen acciones que buscan impedir que la amenaza de lesión definitiva se inicie. Así, "algunos sistemas de reparación de daños tienen dentro de sus objetivos la prevención de futuros daños. Formas específicas de reparación pueden cumplir esta función preventiva, como por ejemplo, las órdenes judiciales que pueden darse cuando el

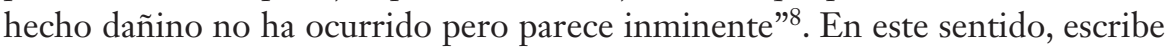
el profesor Tomás Restrepo -quien se aparta parcialmente de mi posición-:

... pese a la controversia circundante sobre el remedio preventivo, esta medida está claramente desarrollada en algunos ordenamientos jurídicos como propia de la responsabilidad civil. En el common law la quia timet injunction es una condena de liability que pretende evitar la causación de un daño o la continuación de

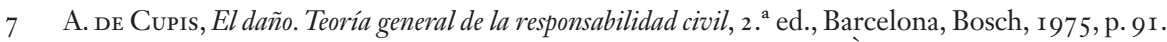
Ver, en un sentido similar, la posición de M. El KHoli, citada por M-È. Roujou de BoubéE, Essai sur la notion de réparation, tesis, París, LGDJ, I974, p. I99: "La amenaza de un perjuicio futuro ya constituye un perjuicio actual y cierto, y 'únicamente existe una diferencia de grado y de tiempo entre la amenaza y el mayor perjuicio temido"”.

8 W. van Gerven, Jeremy Lever y Pierre Larouche, Cases, Materials and Text on National, Supranational and International Tort Law, Oxford y Portland, Hart Publishing, 2000, p. 74I. 
la vulneración, ante la presencia de una amenaza que pueda generar un perjuicio irreparable pecuniariamente. Así mismo, la jurisprudencia alemana, los códigos de las obligaciones suizo y polaco, y los códigos civiles portugués, húngaro, austriaco y de Luisiana, otorgan a la condena de responsabilidad civil un contenido preventivo 9 .

9. La explicación de por qué la definición de daño ha sido restrictiva. Haciendo un recorrido histórico de la institución de la responsabilidad civil se observa que la restricción del concepto de daño ha tenido explicaciones provenientes de la manera como el Código Civil de Napoleón, del cual somos tributarios, concibió la materia. En efecto, su concepción individualista, aunada a la limitación innecesaria pero recurrente que se le dio a la noción de patrimonio -integrado solo por bienes y derechos mesurables en dinero-, hacía imposible que el daño se pudiera concebir de la manera como lo hemos definido.

Pero baste por ahora anotar que ni siquiera en los más tradicionales doctrinantes del derecho francés la posición era clara. Es así como, en un texto evocador y poco citado,

... los hermanos Mazeaud hacen otro reproche a la teoría clásica: en esta concepción el patrimonio solo comprende los bienes pecuniarios. Para los hermanos Mazeaud no hay, sin embargo, ninguna razón que permita excluir del patrimonio de una persona los derechos no pecuniarios de los cuales es titular. Se argumenta que, por no poder ser embargados por los acreedores, dichos derechos no forman parte del patrimonio. Pero existen derechos pecuniarios, es decir, indiscutiblemente 'pecuniarios', que tampoco son embargables (derecho a alimentos, por ejemplo). Es cierto, además, que numerosos derechos de la personalidad tienen incidencia económica; por ejemplo, el derecho a la filiación supone el de alimentos y los de sucesión. Aún más, la lesión de estos derechos da lugar a una acción en responsabilidad civil que se traduce por una suma de dinero. Debemos, sin embargo, anotar que una tal suma de dinero no representa el valor del bien lesionado sino una contrapartida pecuniaria del perjuicio causado con la afrenta de tal bien. Hay pues razones suficientes para no separar en dos compartimientos impermeables los derechos pecuniarios y los no pecuniarios. Tanto los unos como los otros se confunden en el contenido de todos los derechos de la persona, que constituyen su patrimonio, porque tanto unos como otros están afectados a ella. La jurisprudencia y la doctrina no parecen, sin embargo, compartir este punto de vista ${ }^{\mathrm{IO}}$.

9 T. Restrepo Rodríguez, "El remedio preventivo en la responsabilidad civil", Revista de Derecho Privado n. ${ }^{\circ}$ I4, Universidad Externado de Colombia, enero-junio de 2008, pp. 22 I-22 2.

io H. y L. Mazeaud y F. Chabas, Leçons de droit civil, Introduction à l'étude du droit, t. I, i 2. .a ed., París, Montchrestien, 2000, p. 425. 
Es esta la posición que aquí se toma y que tendrá efectos concretos sobre el presente escrito: los derechos no pecuniarios son obligatoriamente protegidos en caso de lesión, y se puede aun afirmar que pertenecen a una concepción amplia de la noción de patrimonio, como se ha visto con los hermanos MAzEAUd. Si bien no es el momento de entrar a cuestionar una definición tan sólidamente anclada en el derecho privado, sí debe al menos afirmarse que la limitación de la noción de patrimonio a los solos derechos pecuniarios produjo nefastas consecuencias sobre el conjunto de la reparación civil, consecuencias que, por fortuna, han ido superándose poco a poco.

\section{B. Concepto de reparación}

Io. La elección terminológica. 'Reparar', 'indemnizar', 'resarcir', 'restablecer', 'volver las cosas al estado anterior', 'compensar', son algunos términos que se encuentran en el corazón del debate sobre el alcance de la reparación de daños. La diversidad de formas como se enuncia el mismo fenómeno es de por sí la primera dificultad que se enfrenta a la hora de descifrar su alcance, razón por la cual es preciso proceder a una cuidadosa escogencia terminológica para evitar equívocos, puesto que, por lo demás, en los diversos campos de la responsabilidad civil estos términos son empleados en ocasiones como sinónimos. Se debe, entonces, investigar su sentido corriente y su sentido jurídico, a efectos de justificar la elección por la cual se opte.

I I. Los sentidos corrientes de los términos anteriores y su sinonimia. Se debe observar el sentido corriente de los términos anteriores. De acuerdo con el Diccionario de la lengua española ${ }^{\text {I }}$, 'reparación' significa “desagravio, satisfacción completa de una ofensa, daño o injuria"; por su parte, 'restablecimiento' designa "acción y efecto de restablecer o restablecerse", y 'restablecer' significa "volver a establecer algo o ponerlo en el estado que antes tenía”; 'indemnización' significa “acción y efecto de indemnizar", e 'indemnizar' corresponde a la acción de "resarcir un daño o perjuicio". Finalmente, 'resarcir' significa "indemnizar, reparar, compensar un daño, perjuicio o agravio". El sentido corriente de estos términos es similar, y la semejanza entre ellos es tal que en los diccionarios de sinónimos ${ }^{\mathrm{I} 2}$, cuando se busca, por ejemplo, 'indemnizar', se reenvía a los verbos 'reparar', 'compensar', 'resarcir'.

I 2. La elección a favor del término 'reparación'. Puesto que es usanza de alguna parte de la doctrina, sobre todo francesa, limitar el concepto de indemnización a aquella pecuniaria, se considera que para impedir esa confusión es preferible utilizar una palabra más omnicomprensiva, que es aquella de 'reparación'. El verbo

I I Diccionario de la lengua española, 2 I. ${ }^{a}$ ed., Real Academia Española, Madrid, Talleres Gráficos Peñalara, I992.

I Diccionario vox esencial de la lengua española. Sinónimos y antónimos, Barcelona, Bibliograf, I 995. 
'reparar' supone, como se acaba de reseñar, la existencia de diversas maneras que permiten volver a su estado anterior lo que ha sido dañado. 'Reparar' es más amplio que 'indemnizar'. Por ello se prefiere aplicar, para los fines de este estudio, la expresión 'reparar los daños' en lugar de 'indemnizar los daños'. En efecto, se considera que para no restringir el ámbito de aplicación de la responsabilidad civil, de acuerdo con las consideraciones expuestas en la definición dada de daño al inicio de este escrito, conviene utilizar el verbo 'reparar' en su acepción amplia para comprender mejor el fin de la responsabilidad civil.

Adoptar esta posición permite adherir a las definiciones amplias que son dadas en múltiples ámbitos jurídicos, por ejemplo en el derecho internacional, que aprehende la reparación como "todo acto o prestación de un Estado en beneficio de otro y de su demanda, que tiene por objeto poner fin a un litigio relativo a un perjuicio sufrido por el segundo por el hecho del primero" I3.

I 3. Definición personal de reparación. Con las precisiones anteriores, me permito definir 'reparación' de la siguiente forma: es la manera como el responsable cumple la obligación de reparar asegurando a la víctima el retorno al status quo ante al acaecimiento del daño.

I4. Las ventajas de una definición amplia de reparación. La definición que acaba de presentarse permite ubicar la noción de tal manera que en ella quepan todas las formas de retorno al status quo ante. El punto es de importancia, porque permite corroborar que "toda lesión a un interés lícito es un daño reparable y [que] el conjunto de daños reparables se somete al mismo régimen" ${ }^{4}$, lo cual implica, por lo demás, que "ninguna rama del derecho puede existir sin reparación"I5. Uniendo las dos citas precedentes, se puede decir que en toda rama del derecho se deben predicar las reglas generales utilizadas para reparar, lo cual constituye el hilo conductor del presente escrito. Esta concepción es quizás más cercana de la noción de remedy del derecho anglosajón que de aquella restrictiva de reparación en Europa. En efecto,

... la noción inglesa de remedy es una noción más amplia que aquella de reparación, como es entendida habitualmente en Francia. Para iniciar, se trata de una noción transversal aplicable tanto a responsabilidad contractual como extracontractual. Además, esta noción trasciende otra división tradicional del derecho inglés que es la división entre law y equity. El derecho inglés dispone de gran variedad de remedies que se subdividen en equitable y legal remedie, compuesto cada

I 3 Ch. Dominice, "La réparation non contentieuse", en La responsabilité dans le système international, Colloque du Mans, Société française pour le droit international, París, Pedone, I99 I, p. I9I.

I4 B. GIRARD, Responsabilité civile extracontractuelle et droits fondamentaux, París, LGDJ, BDP, t. 562, 2015 , p. I 73 .

i 5 Van Gerven, Lever y Larouche, Cases, Materials and Text on National, Supranational and International Tort Law, cit., p. 739. 
grupo de diversas formas de reparar que van de las más clásicas, como damages o specific performance, hasta las más originales, como la creación de fiducias. Finalmente, mientras que en Francia la noción de reparación se limita al daño consumado, los remedies ingleses tienen no solo función de reparación sino también de prevención o de protección. Por esta vía se encuentran no solo la medida de reparación pecuniaria o la reparación por equivalente, sino medidas como el derecho de retención en materia contractual o el conjunto de medidas cautelares ${ }^{16}$.

Se trata entonces de asimilar la concepción amplia de reparación que predicamos en este escrito con la noción de remedy anglosajona, lo cual permite retomar lo dicho cuando se estudió la definición de daño, en el sentido de que gracias a la noción expuesta de reparación será posible concebir dicho término para las situaciones en las cuales el daño se presenta bajo la faceta de la alteración de su goce pacífico sin que aún se haya iniciado la consumación de la lesión del derecho, respecto de todas las hipótesis de daños colectivos y de daños individuales; $y$, finalmente, hace posible concebir que la reparación se encuentra lejos de estar limitada a la meramente pecuniaria.

I 5. La definición amplia de reparación tiene apoyo en normas internacionales. Dentro de las múltiples normas de derecho internacional, ya sean tratados o soft $l a w^{17}$, quiero resaltar dos importantes resoluciones de la Asamblea General de la

I6 O. Boskovic, La réparation du préjudice en droit international privé, París, LGDJ, BDP, t. 407, 2003, p. $2 \mathrm{I}$.

I 7 A propósito de la postura de la Corte Constitucional frente a la herramienta del soft law como fuente de derecho, cabe resaltar que la corporación ha acudido al derecho blando de dos maneras. Por una parte, lo ha concebido como un parámetro interpretativo en varios de sus pronunciamientos, por ejemplo en las sentencias C-228 de 2002 y C-53 I de 2006 (las cuales hacen referencia a los derechos de las víctimas), donde la Corte cita la "Declaración sobre los principios fundamentales de justicia para las víctimas de delitos y del abuso de poder" y los "Principios y directrices básicos sobre el derecho de las víctimas de violaciones manifiestas de las normas internacionales de derechos humanos y de violaciones graves del Derecho Internacional Humanitario a interponer recursos y obtener reparaciones", ambos instrumentos de soft law. En este sentido es relevante la sentencia C-370 de i 8 de mayo de 2006, donde se afirma como principio general interpretativo que "[1] os funcionarios judiciales a su vez, deben tener como criterio interpretativo relevante, la doctrina elaborada por los organismos internacionales de control de los tratados, como la Comisión Interamericana de Derechos Humanos y la jurisprudencia de la Corte Interamericana de Derechos Humanos. Se trata de una visión integral de los derechos humanos que permitirá cumplir con los estándares internacionales en materia de derechos humanos, derecho internacional humanitario y derecho penal internacional, de los cuales también hacen parte los principios generales del derecho internacional y la costumbre internacional". Por otra parte, el juez constitucional incorpora al mismo bloque de constitucionalidad los apartes de tales instrumentos, que desarrollan normas de los tratados de derechos humanos y del derecho internacional humanitario que forman parte del bloque, "convirtiendo instrumentos de derecho blando (soft law) del derecho internacional en derecho duro (hard law) en el orden interno" (ver, sobre este punto, la sentencia SU-I I 50 de 2000 respecto a los "principios rectores relativos al desplazamiento forzado"). Finalmente, ver: sentencia C-228 del 3 de abril de 2002, actor: Ricardo Danies González, exp. D-3672; sentencia SU-I I 50 del 30 de agosto de 2000, actores: Regional de Antioquia de la Defensoría 
Organización de las Naciones Unidas para corroborar el anterior aserto. En primer lugar, la Resolución $56 / 83$ de $\mathrm{I} 2$ de diciembre de $200 \mathrm{I}^{[\mathrm{I} 8]}$, sobre responsabilidad del Estado por hechos internacionalmente ilícitos ${ }^{19}$. En segundo lugar, la Resolución 60/I47, aprobada el I6 de diciembre de $2005^{[20]}$, resultado de varios informes presentados por el experto Theo VAN Boven. Esta última resolución se refiere específicamente a los "Principios y directrices básicos sobre el derecho de las víctimas de violaciones manifiestas de las normas internacionales de los derechos humanos y de violaciones graves del derecho internacional humanitario a interponer recursos y obtener reparaciones".

Todo pareciera indiciar que en el campo de los derechos humanos los trabajos de VAN Boven han silenciado la importante resolución de 200 I. Sin demeritar para nada la resolución originada en VAN Boven, se debe advertir que los principios generales de las reparaciones se encuentran, no en dicha resolución, sino en aquella de $200 \mathrm{I}$ de la onU. Sin lugar a dudas se puede afirmar que la resolución de 200 I tiene un campo de aplicación más amplio que la primera, porque para CRAWFORD, interpretando el artículo 28 con el i de la resolución de 200 I, es claro que "esta resolución se aplica a todas las obligaciones internacionales de los Estados y no solo a aquellas que son debidas por otros Estados. Así, la responsabilidad de los Estados se extiende por ejemplo a las violaciones de

del Pueblo contra la Inspección 8B Municipal de Policía de Antioquia, el Ministerio del Interior, la Gobernación de Antioquia y la Alcaldía de Medellín; Marco Tulio Ararat Sandoval contra la Secretaría de Vivienda Social y Renovación Urbana de Cali, y Jairo Vicente Reyes Cabrera contra la Red de Solidaridad Social, exps. T-г 86589, T-20 г6 I 5 y T-25494I (acumulados).

Con independencia de que se considere o no que el soft law pueda en algunas ocasiones aplicarse en Colombia, sugiero igualmente las siguientes lecturas sobre el tema: D. E. López Medina y A. L. SÁnchez Mejía, "La armonización del derecho internacional de los derechos humanos con el derecho penal colombiano", International Law: Revista Colombiana de Derecho Internacional n. ${ }^{\circ}$ I 2, Pontificia Universidad Javeriana, enero-junio de 2008, pp. 3 I 7-35 I; G. Gallón Giraldo y M. Reed Hurtado (eds.), Principios internacionales sobre impunidad y reparaciones, Bogotá, Comisión Colombia de Juristas, 2007, p. I9: "los principios internacionales sobre reparación deben ser observados obligatoriamente en Colombia, por mandato expreso de los artículos 9, 93 y 94 de la CP. Es decir, que tales principios internacionales vinculan a Colombia".

I 8 En su artículo 34, sobre formas de reparación, se enuncia: "La reparación íntegra del perjuicio causado por el hecho internacionalmente ilícito adoptará la forma de restitución, de indemnización y de satisfacción, ya sea de manera única o combinada, de conformidad con las disposiciones del presente capítulo".

I9 Sobre esta importante resolución se recomienda la lectura de J. CRAwFord, Les articles de la C.D.I. sur la responsabilité de l'État, París, Pedone, 2003, p. 232. En inglés: The International Law Commission's Articles on State Responsibility. Introduction, Text and Commentaries, Cambridge University Press, 2002.

20 En el artículo i 8 se establecen las formas de reparación, así: "Conforme al derecho interno y al derecho internacional, y teniendo en cuenta las circunstancias de cada caso, se debería dar a las víctimas de violaciones manifiestas de las normas internacionales de derechos humanos y de violaciones graves del derecho internacional humanitario, de forma apropiada y proporcional a la gravedad de la violación y a las circunstancias de cada caso, una reparación plena y efectiva, según se indica en los principios iq a 23, en las formas siguientes: restitución, indemnización, rehabilitación, satisfacción y garantías de no repetición”. 
los derechos humanos y a otras violaciones del derecho internacional cuando el beneficiario principal de la obligación violada no es un Estado". Prueba de ello son los múltiples casos citados por Crawford en su libro, que tienen que ver con todos los campos del derecho y con la integralidad de la jurisprudencia de la Corte Internacional de Justicia ${ }^{21}$. Esta universalidad de la resolución de 200 I se corrobora con el artículo 26 de la resolución de 2005 cuando afirma que "nada de lo dispuesto en los presentes Principios y directrices básicos se interpretará en el sentido de que restringe o deroga cualquiera de los derechos u obligaciones dimanantes del derecho interno y del derecho internacional". La Resolución $56 / 83$ de 200 I constituye pues un esfuerzo por convertir en norma jurídica los trabajos académicos y de sistematización que venía desarrollando la Comisión de Derecho Internacional de la onv en materia de responsabilidad internacional de los Estados. Con todo, no se ha logrado que dichos trabajos se conviertan en un tratado internacional, con la fuerza vinculante que esto conllevaría (obligatoriedad, establecimiento de responsabilidad por incumplimiento, tribunal para llevar demandas, etc.), al igual que ocurre con la del año 2005.

Mas no son solamente las importantes resoluciones de la onu que se acaban de reseñar las que promueven la concepción amplia del concepto de reparación. Igualmente existen normas internacionales vinculantes para Colombia. Es lo que ocurre, a nivel de ejemplo, con los artículos 8, 25 y $6_{3}$ de la Convención Americana de Derechos Humanos, que son el sustento para las reparaciones amplias que ordena la Corte Interamericana de Derechos Humanos ${ }^{22}$. Es igualmente el caso del Estatuto de Roma de la Corte Penal Internacional, cuyo artículo 75 se refiere a la reparación de las víctimas²3.

Pero no es solo en el campo de los derechos humanos en donde existen normas internacionales que consagran una concepción amplia de la reparación. Así, en materia de derecho internacional privado, podemos traer a colación los Principios UNIDROIT, los cuales constituyen lex mercatoria, pues recopilan la práctica jurídica en el comercio internacional. Además de ser invocados a menudo como

2 I Se recomienda visitar su página web, donde se encuentran sentencias y opiniones consultivas en versión en inglés: http://www.icj-cij.org/ y en francés: http://www.icj-cij.org/homepage/index. php, con excelentes motores de búsqueda.

22 C. Steiner y P. Unibe (eds.), Convención Americana sobre Derechos Humanos, Bogotá, Editorial Temis y Konrad Adenauer Stiftung, 2014, p. 828: "La obligación de reparar en la Convención está establecida como una obligación que impone la Corte cuando decide que se ha vulnerado un derecho establecido por ella. Ella comprende dos situaciones, descritas en la primera y en la segunda oración del artículo 63. I : la obligación de garantizar los derechos o libertades conculcados, y la obligación de reparar tales violaciones. Sin embargo, esta distinción ha sido, en parte, superada en la jurisprudencia de la Corte por aquella que se basa en una noción de reparación integral, y que comprende medidas de restitución, compensación, rehabilitación, satisfacción y garantía de no repetición".

23 Art. 75, num. 2: "La Corte podrá dictar directamente una decisión contra el condenado en la que indique la reparación adecuada que ha de otorgarse a las víctimas, incluidas la restitución, la indemnización y la rehabilitación”. 
instrumentos para la solución de conflictos internacionales de carácter privado, estos también sirven de "naturalia negotia, que suministr[a]n material para la integración del contenido de los contratos, sea por reenvío directo, sea porque adquieren la calidad de lex mercatoria, sea, en fin, porque se llegue a reconocer en ellos el dictado de la equidad" 24 . En referencia a la reparación del daño, dichos Principios acogen la reparación integral del mismo y establecen que "el daño comprende cualquier pérdida sufrida y cualquier ganancia de la que fue privada [la víctima]". Además, consagran que el daño "puede ser no pecuniario e incluye, por ejemplo, el sufrimiento físico y la angustia emocional" 25 . También se presentan modalidades de reparación como las reseñadas para otras áreas del derecho, cual ocurre con la compensación (art. 8.I); con la interesante figura que trae el artículo 7.3.4, que "abre al acreedor que razonablemente puede considerar la inejecución, esencial de su deudor, la posibilidad de exigir 'medidas suficientes que aseguren la buena ejecución'”; con el artículo 7.I.4, "que reconoce al deudor de una obligación incumplida el derecho de tomar cualquier medida para corregir la inejecución", y con los artículos 7.2.I y 7.2.2, "que sientan el principio de ejecución in natura a favor del acreedor, atenuada por cinco excepciones en materia de obligaciones no pecuniarias"; además de con "el principio según el cual los bienes culturales ilícitamente exportados deben ser restituidos al Estado reclamante" ${ }^{26}$.

Dichos postulados, que sirven de principios generales de interpretación de contratos en el derecho europeo, se ven aplicados en varios campos del derecho privado. Téngase como ejemplo el ámbito de la propiedad industrial, cuyo referente normativo supranacional aplicable en Colombia es la Decisión Andina 486 de 2000 . Según el profesor Rengifo, el artículo 243 de tal instrumento ${ }^{27}$ acoge la reparación integral como criterio en aras de calcular la indemnización de daños y perjuicios cuando exista infracción frente a un derecho relacionado con la

24 Fernando Hinestrosa, "Los Principios de unidroit: una nueva lingua franca", en Principios sobre los contratos comerciales internacionales, Bogotá, Ministerio de Justicia, I997, p. 2 I .

25 Principios unidroit: "Artículo 7.4.2 (Reparación integral) (I) La parte perjudicada tiene derecho a la reparación integral del daño causado por el incumplimiento. Este daño comprende cualquier pérdida sufrida y cualquier ganancia de la que fue privada, teniendo en cuenta cualquier ganancia que la parte perjudicada haya obtenido al evitar gastos o daños y perjuicios. (2) Tal daño puede ser no pecuniario e incluye, por ejemplo, el sufrimiento físico y la angustia emocional".

26 I. RuEDA, Incidences des règles d'Unidroit sur le droit des contrats en Europe, París, LGDJ, BDP, t. 559, $20 \mathrm{I} 5$, pp. 4I, 62 y $25 \mathrm{I}$.

27 Decisión Andina 486 de 2000: "Artículo 243. Para efectos de calcular la indemnización de daños y perjuicios se tomará en cuenta, entre otros, los criterios siguientes: a) el daño emergente y el lucro cesante sufrido por el titular del derecho como consecuencia de la infracción; b) el monto de los beneficios obtenidos por el infractor como resultado de los actos de infracción; o, c) el precio que el infractor habría pagado por concepto de una licencia contractual, teniendo en cuenta el valor comercial del derecho infringido y las licencias contractuales que ya se hubieran concedido". 
propiedad industrial. En este orden, la norma no solo establece la obligación de responder por los perjuicios materiales sufridos, sino que, de manera implícita, trata también sobre la reparación de los daños morales ${ }^{28}$.

I6. La definición amplia de reparación tiene eco en la ley y en la doctrina nacionales. Lo dicho en el parágrafo anterior se aplica también a nuestra normativa y jurisprudencia nacionales. Vale la pena mencionar el artículo 8. ${ }^{\circ}$ de la Ley 975 de 2005 -Ley de Justicia y Paz- que "se refiere específicamente al 'derecho a reparación'. Allí se establece el contenido de este derecho y se precisa que el mismo comprende 'las acciones que propendan por la restitución, la indemnización, la rehabilitación, la satisfacción y las garantías de no repetición['], definiendo cada uno de tales conceptos, y agregando el contenido de lo que se ha de entender por 'reparación simbólica' y por 'reparación colectiva'”29. Se debe anotar que dicho artículo fue derogado por el artículo 4I de la Ley I 592 de 20 I 2 -modificatoria de la Ley 975 de 2005-, en la cual se recordó el texto del mencionado artículo 8. ${ }^{\circ}$ aunque no se reprodujo su contenido, y en la cual se remite a la Ley I 448 de 20 I I, que estableció medidas de atención, asistencia y reparación integral a las víctimas del conflicto armado interno, especialmente en su artículo $25^{\left[3^{\circ}\right]}$.

$\mathrm{Al}$ igual que en el tema internacional tratado en el parágrafo precedente, en el derecho colombiano también existen campos por fuera de los derechos humanos en los que el legislador acoge una definición amplia de reparación. Tal es el caso de la valoración del daño derivado de la violación de un derecho de autor en el ámbito del derecho nacional. En efecto, consciente de la dificultad de estimar tales perjuicios, el legislador colombiano "proporciona al juzgador tres criterios para la tasación de los perjuicios materiales causados por el hecho: I. El valor comercial de los ejemplares producidos o reproducidos sin autorización. 2. El valor comercial que hubiere percibido el titular del derecho de haber autorizado su explotación. 3. El lapso durante el cual se efectuó la explotación ilícita ${ }^{31}{ }^{32}$.

La concepción amplia de reparación se corrobora en la jurisprudencia de la Corte Constitucional. Así, en la sentencia C-9i6 de 2002, la corporación esta-

E. Rengifo García, "Valoración de perjuicios en la infracción de las patentes", artículo inédito, generosamente facilitado por el autor.

29 C. López Díaz (coord.), Daño y reparación judicial en el ámbito de la Ley de fusticia y Paz, Bogotá, GTz, Fiscalía General de la Nación y Embajada de la República Federal de Alemania, 2oro, p. 2 I 7 .

30 Ley I448 de 20 I : "Artículo 25. Derecho a la reparación integral. Las víctimas tienen derecho a ser reparadas de manera adecuada, diferenciada, transformadora y efectiva por el daño que han sufrido como consecuencia de las violaciones de que trata el artículo $3 .^{\circ}$ de la presente Ley. La reparación comprende las medidas de restitución, indemnización, rehabilitación, satisfacción y garantías de no repetición, en sus dimensiones individual, colectiva, material, moral y simbólica. Cada una de estas medidas será implementada a favor de la víctima dependiendo de la vulneración en sus derechos y las características del hecho victimizante".

3 I Ver art. 57 Ley 44 de I993.

32 Rengifo García, "Valoración de perjuicios en la infracción de las patentes", cit. 
blece que la Carta Política no precisa los daños que deben ser reparados, ni el modo en que estos se deben cuantificar. En este sentido,

... el legislador, al definir el alcance de la 'reparación integral' puede determinar cuáles daños deben ser tenidos en cuenta, y en esa medida incluir como parte de la reparación integral los daños materiales directos, el lucro cesante, las oportunidades perdidas, así como los perjuicios morales, tales como el dolor o el miedo sufridos por las víctimas, los perjuicios estéticos o los daños a la reputación de las personas, o también los llamados daños punitivos, dentro de límites razonables. Puede también el legislador fijar reglas especiales para su cuantificación y criterios para reducir los riesgos de arbitrariedad del juez. Estos criterios pueden ser de diverso tipo. Por ejemplo, pueden consistir en parámetros que orienten al juez, en límites variables para ciertos perjuicios en razón a lo probado dentro del proceso para otra clase de perjuicios, o en topes fijos razonables y proporcionados 33 .

De igual forma debe considerarse la sentencia C-7I5 de 20I2, que estudió la constitucionalidad de algunos artículos de la Ley I 448 de 20 I I, en la cual se dijo:

El derecho a la verdad se encuentra vinculado con el derecho a la reparación, ya que el conocimiento de lo sucedido para las víctimas y sus familiares, constituye un medio de reparación [...] las obligaciones de reparación incluyen, en principio y de manera preferente, la restitución plena (restitutio in integrum), que hace referencia al restablecimiento de la víctima a la situación anterior al hecho de la violación, entendida ésta como una situación de garantía de sus derechos fundamentales, y dentro de estas medidas se incluye la restitución de las tierras usurpadas o despojadas a las víctimas; [...] El daño acaecido por la violación flagrante de los derechos humanos, genera a favor de la víctima el derecho fundamental a la reparación de los perjuicios directamente ocasionados con la trasgresión, a través de la restitución, la indemnización, la rehabilitación, la satisfacción y la garantía de no repetición consagradas en el Derecho Internacional34.

También es de obligatoria consulta la sentencia C-I80 de 20I4, en la cual se declaró la exequibilidad de algunos apartes del inciso quinto del artículo 23 de la Ley 1592 de $20{ }_{2}{ }^{[35]}$. Como se observa en las sentencias que se acaban de referir,

33 Si bien debe aclararse que el aparte citado corresponde a un obiter dictum de la referida sentencia, este resulta clave para comprender los temas en materia de reparación que se tratarán a continuación. Corte Constitucional, C-916 del 29 de octubre de 2002, actor: Camilo Andrés Baracaldo Cárdenas, exp. D-4020.

34 Corte Constitucional, C-7 I 5 del I 3 de septiembre de $20{ }_{2} 2$.

35 Corte Constitucional, C-1 80 del 27 de marzo de 2014, que en lo pertinente afirma: "A partir del marco constitucional antes presentado y los lineamientos que al respecto ha establecido el 
no solo se considera que se aplica la reparación integral, sino que la reparación es un derecho fundamental, lo cual recoge una línea jurisprudencial que ya venía de la sentencia T-o8 5 de 2009. Frente a un caso de desplazamiento forzado, la Corte fue enfática al exponer que "los accionantes al ser víctimas del desplazamiento forzado a causa de la violencia tienen el derecho fundamental a ser reparados con ocasión del daño derivado de la transgresión masiva de los derechos fundamentales, toda vez que el perjuicio causado no es una carga que debían soportar, sino que, por el contrario, es el resultado de la ausencia en la garantía de los derechos fundamentales por parte del Estado" 36 .

Esta lógica debe entenderse extendida a todas las áreas de la producción de daños, como ya ha quedado sugerido gracias a la citación de varios campos de la responsabilidad civil extracontractual del Estado en los cuales se aplican similares medidas de reparación.

\section{Segunda parte.}

\section{Las diversas formas de reparación de daños}

I 7. La influencia de la definición de reparación sobre las formas de reparación. Con independencia de las discusiones que se puedan presentar respecto de las formas concretas de reparación, se debe partir de que hay coincidencia doctrinaria en el sentido de que la reparación pecuniaria y la reparación en especie o in natura son unánimemente aceptadas. Por el contrario, las medidas tendientes a la prevención del daño, a las reparaciones simbólicas y similares, así como aquellas destinadas a la cesación del ilícito, no son aceptadas de manera unánime o bien se caracterizan por una novedad que las hace inusuales en el conjunto de la responsabilidad civil. A diferencia de lo que ocurre en nuestro medio, "históricamente el TEDH sólo ha favorecido las reparaciones declarativas y la compensación monetaria" 37 . Ello se debe a que la reparación es un concepto que, como ya se vio, puede ser concebido de manera amplia o estricta: "En este sentido, podemos considerar que la reparación ostenta una definición estricta que excluye las medidas preventivas de restablecimiento y una definición amplia que permite que estas últimas sean calificadas como medidas de reparación en especie" ${ }^{8}$, para hablar solo de esta faceta de las reparaciones.

derecho internacional, se establece que en materia de reparación las víctimas tienen en términos generales dos derechos: i) a tener y poder ejercer un recurso accesible, rápido y eficaz para obtener la reparación y ii) a ser reparadas adecuadamente por los perjuicios sufridos".

36 Corte Constitucional, T-08 5 del r 6 de febrero de 2009.

37 Steiner y Uribe (eds.), Convención Americana sobre Derecbos Humanos, cit., p. 27 I.

38 M. Boutonnet, Le principe de précaution en droit de la responsabilité civile, París, LGDJ, BDP, t. 444, 2005 , p. 322. 
I8. El estudio de las formas de reparación no coincide con el de la tipología de daños. Las formas de reparación se aplican a los rubros del daño, pero formas de reparación y daño no son conceptos sinónimos. Una cosa es admitir la presencia de un determinado daño, como pueden ser, para citar algunos ejemplos, el moral, el lucro cesante o el daño a la vida de relación, y otra cosa es estudiar cómo la jurisprudencia de un determinado país busca su reparación. El gran debate en este punto se orienta a impedir que las diversas formas de reparación resarzan idéntico daño, y la respuesta exitosa consistirá en que cualquier clasificación de rubros del daño determine con claridad qué y cómo se repara, para no violentar la regla de la prohibición de indemnizar dos veces el mismo daño39. El tema es fácil de resolver en lo que tiene que ver con los daños pecuniarios o materiales, puesto que su medición en dinero permite que, ya sea in natura o en equivalente pecuniario, la reparación se otorgue por este medio. Igual ocurre con la usanza que se tiene en Colombia de indemnizar en salarios mínimos legales vigentes determinados rubros de los daños no pecuniarios o inmateriales, cuya fijación en metálico no cambia la naturaleza no mesurable del derecho lesionado. Es simplemente una comodidad entendible del juez para racionalizar la reparación de este tipo de daños. El problema se presenta cuando se conjugan varios daños no pecuniarios, donde el operador jurídico habrá de tener sumo cuidado en no reparar dos veces el mismo daño. Es decir, en lo relacionado con los daños no pecuniarios, no se trata de afirmar que cada rubro tiene una forma específica de ser reparado, porque todo dependerá del caso concreto, en el cual pueden darse varias de sus formas.

I9. Observaciones generales a las diferentes acciones procesales en el Código de Procedimiento Administrativo y de lo Contencioso Administrativo (CPACA). Previo al desarrollo del plan de esta segunda parte, resulta oportuno hacer algunas reflexiones sobre las acciones o medios de control contemplados en la Ley I437 de 20 I I. Una primera observación consiste en precisar que, a pesar del cambio terminológico de 'acción procesal' a 'medio de control', a mi juicio dicha modificación es insustancial40 ${ }^{\circ}$, y ello en la medida en que, si bien es cierto se incluyeron nuevos medios de control, los tradicionales no tuvieron alteraciones de importancia. Una segunda consideración permite afirmar que el CPACA consagra posiciones que van en contra de lo que aquí se escribe. Así, por ejemplo, en el artículo i 38 ,

Sobre esta temática remito a dos obras de mi autoría, complementarias a lo que aquí se escribe: "De las distintas formas de concebir la tipología de perjuicios", en Responsabilidad civil, derecho de seguros y filosofía del derecho. Homenaje al profesor Favier Tamayo Faramillo, t. I, Bogotá, Diké, 20 I , pp. I 39- - 67, y El daño. Análisis comparativo de la responsabilidad extracontractual del Estado en derecho colombiano y francés, Bogotá, Universidad Externado de Colombia, I998, cap. segundo.

40 Ver, a este propósito, C. Sarria Olcos, en Código de Procedimiento Administrativo y de lo Contencioso Administrativo. Ley I437 de 20 I I. Comentado y concordado, J. L. Benavides (ed.), Bogotá, Universidad Externado de Colombia, 2013, p. 305: "De conformidad con lo anterior, es claro que el legislador suprimió la denominación de 'acciones' y la sustituyó por 'medios de control', pero mantuvo respecto de cada uno de ellos su propia definición y regulación”. 
cuando define la acción de nulidad y restablecimiento del derecho, sigue con la dicotomía, que será objeto de crítica posteriormente en este trabajo, de que una cosa es restablecer el derecho y otra es la reparación del daño. Creo que, como se verá luego, el restablecimiento del derecho como reparación in natura es la forma por excelencia de reparar daños. De igual manera, en el artículo i40, cuando define el medio de control de la reparación directa, afirma que se desarrolla "en los términos del artículo 90 de la Constitución Política [para] demandar directamente la reparación del daño antijurídico producido por la acción u omisión de los agentes del Estado". Resulta infortunado hacer la citación del artículo $90 \mathrm{CP}$ para referirse a una sola acción de las contempladas en el Código, como si solo se pudiera comprometer la responsabilidad del Estado "cuando la causa del daño sea un hecho, una omisión, una operación administrativa o la ocupación temporal o permanente de inmueble por causa de trabajos públicos o por cualquiera otra causa imputable a una entidad pública o a un particular que haya obrado siguiendo una expresa instrucción de la misma”. Y es infortunada dicha restricción porque allí donde haya condena al Estado el fundamento de la misma será el artículo 9o CP. Es decir, este artículo es el fundamento constitucional de todas las acciones contencioso administrativas, ordinarias y/o constitucionales donde haya pretensiones en contra del Estado ${ }^{4}$.

20. Apoyo normativo y conceptual para la clasificación por la cual se opta. Para desarrollar las formas concretas de reparación de daños me remito, en consonancia con lo afirmado anteriormente, a los textos que contemplan la noción amplia de reparación.

Se debe así tener en cuenta lo ya mencionado en la Resolución 56/83 de la onu, que coincide con aquello que se deduce del Sistema Interamericano de Derechos Humanos, para efectos de aplicar los principios amplios de reparación

4I Ver, por ejemplo, C.E., Sección III, 8 de mayo de I995, C.P.: Juan de Dios Montes Hernández, exp. 8 i 8 , en donde se afirma: "esa laboriosa construcción jurisprudencial permitió, al cabo de muchos años, la consagración de un principio constitucional constitutivo de la cláusula general de responsabilidad patrimonial del Estado, tanto de naturaleza contractual como extracontrato". Tal postura jurisprudencial ha sido ratificada por la misma Sala en recientes pronunciamientos. Ver, como ejemplo: C.E., Sección III, I I de agosto de 20 Io, actores: Antonio Vicente Russo y Martha Ligia Salcedo, exp. I 8499. Dicha sentencia se refiere a providencias anteriores provenientes tanto del juez administrativo como del juez constitucional y ratifica la consagración por parte del artículo $90 \mathrm{CP}$ de un régimen general de responsabilidad estatal. A propósito del tema también resulta obligatorio el estudio de la jurisprudencia constitucional. Ver Corte Constitucional, C-333 del r..$^{\circ}$ de agosto de r996, actora: Emilse Margarita Palencia, exp. D-I I I. Dicha providencia establece que para la corporación "el inciso primero del artículo 90 consagra la cláusula general de responsabilidad patrimonial del Estado y comprende por ende no sólo la responsabilidad extracontractual sino también el sistema de responsabilidad precontractual (derivado de la ruptura de la relación jurídicoadministrativa precontractual) así como también la responsabilidad patrimonial del Estado de carácter contractual". Ver, en el mismo sentido, Corte Constitucional, Plenaria, C-892 del 22 de agosto de 200 I, actora: Sonia Durán, exp. D-3404, la cual confirma una vez más la existencia de un régimen unificado de la responsabilidad plasmado en la Carta y reitera que el concepto de daño antijurídico subsume los distintos tipos de responsabilidad estatal. 
ya referidos. En lo atinente a la Resolución $56 / 83$ debe el lector remitirse a la segunda parte de la misma, llamada "Contenido de la Responsabilidad Internacional del Estado”, que a su vez se divide en tres capítulos: r. ${ }^{\circ}$ Principios generales; $2 .^{\circ}$ Reparación del perjuicio, y $3 .^{\circ}$ Violaciones graves de obligaciones emanadas de normas imperativas del derecho internacional general. De dicha normativa vale la pena resaltar el artículo 30 del primer capítulo y los artículos 34 a 37 del segundo. En términos generales, se deduce que lo primero a lo que está obligado un Estado en caso de incurrir en un hecho internacionalmente ilícito es a hacer cesar el hecho ilícito, así como a dar garantías de no repetición (art. $3^{\left[4^{2}\right]}$ ). Además, conforme a los artículos 34 a 37, se definen las tres formas de reparación: la restitución 43 , la indemnización 44 y la satisfacción 45 , las cuales conforman el concepto de reparación integral del artículo 34.

A su turno y con similar orientación,

La CIDH concibe el término reparación en un sentido genérico que permite englobar las más diversas formas de restablecer las violaciones de la Convención Americana. El artículo 63-I de esta Convención reconoce a la CIDH la posibilidad de aplicar varias categorías de reparación: la restitución (colocar a la víctima en la situación en la que ella se encontraría si el hecho dañino no se hubiese producido), la rebabilitación (permitir a la víctima superar el posible trastorno psicológico producido por la lesión), la compensación (indemnización pecuniaria para el daño material e inmaterial), la satisfacción (que permite el restablecimiento de la dignidad humana) y las garantías de no repetición (que tienen por objeto garantizar que el hecho dañino no se repetirá) ${ }^{46}$.

42 Art. 30: "El Estado responsable de un hecho internacionalmente ilícito tiene la obligación: a) de terminar el hecho si el mismo continúa; b) de ofrecer las seguridades y garantías de no repetición apropiadas si las circunstancias lo exigen".

43 Art. 35: "El Estado responsable de un hecho internacionalmente ilícito está obligado a la restitución, es decir, a restablecer la situación que existía antes de la comisión del hecho ilícito, siempre y cuando: a) no sea materialmente imposible, b) no imponga una carga fuera de toda proporción entre la ventaja que derivaría de la restitución en relación con la ventaja que se obtendría con la indemnización".

44 Art. 36: "г. El Estado responsable de un hecho internacionalmente ilícito está obligado a indemnizar el daño causado por el hecho en la medida en que dicho daño no sea reparado por la restitución. 2. La indemnización cubre todo daño susceptible de evaluación financiera, comprendido el lucro cesante en la medida en que éste sea comprobado".

45 Art. 37: "I. El Estado responsable de un hecho internacionalmente ilícito está obligado a dar satisfacción por el perjuicio causado por ese hecho en la medida en que ese perjuicio no pueda ser reparado mediante restitución o indemnización. 2. La satisfacción puede consistir en un reconocimiento de la violación, una expresión de pesar, una disculpa formal o cualquier otra modalidad adecuada. 3. La satisfacción no será desproporcionada con relación al perjuicio y no podrá adoptar una forma humillante para el Estado responsable".

46 A. J. Carrillo, "Justice in context: The relevance of inter-american human rights law and practice to repairing the past", en P. De Greiff (ed.), The Handbook of Reparations, Oxford University Press, 2006, p. 526. 
En derecho colombiano el legislador se ha inclinado también, como ya se ha dicho, por un concepto amplio de reparación. En el parágrafo i6 de este escrito se hizo referencia al punto, y por ello solo resta citar los mencionados artículos de las leyes al respecto. De una parte, la Ley de Justicia y Paz -Ley 975 de $2005^{[47]}$, que fue derogada, como ya se anotó, pero que vale la pena retomar por la ilustración conceptual que contuvo. De otra parte, la Ley I 592 de 20 I ${ }^{[48]}$, que remite a la ley $\mathrm{I} 448$ de 20 I I ${ }^{[4]]}$. Finalmente, para una comprensión general del tema se deben citar dos libros producidos por el Consejo de Estado sobre sentencias de unificación en varios frentes ${ }^{5 \circ}$, pero que referimos para lo atinente a la responsabilidad extracontractual del Estado.

$2 \mathrm{I}$. Presentación del plan de esta segunda parte. Como ya se ha podido vislumbrar en la presentación de la definición amplia de reparación, aceptada tanto a nivel nacional como internacional, quisiera, para fines pedagógicos, dividir en

47 Art. $7 \cdot^{\circ}$ : "El derecho de las víctimas a la reparación comprende las acciones que propendan por la restitución, indemnización, rehabilitación, satisfacción, y las garantías de no repetición de las conductas. Restitución es la realización de acciones que propendan por regresar a la víctima a la situación anterior a la comisión del delito. La indemnización consiste en compensar los perjuicios causados por el delito. La rehabilitación consiste en realizar las acciones tendientes a restablecer la dignidad de la víctima y difundir la verdad sobre lo sucedido. Las garantías de no repetición comprenden, entre otras, la desmovilización y el desmantelamiento de los grupos armados al margen de la ley. Se entiende por reparación simbólica toda prestación realizada a favor de las víctimas o de la comunidad en general que tienda a asegurar la preservación de la memoria histórica, la no repetición de los hechos victimizantes, la aceptación pública de los hechos, el perdón público y el restablecimiento de la dignidad de las víctimas. La reparación colectiva debe orientarse a la reconstrucción sico-social de las poblaciones afectadas por la violencia. Este mecanismo se prevé de manera especial para las comunidades afectadas por la ocurrencia de hechos de violencia sistemática. Las autoridades judiciales competentes fijarán las reparaciones individuales, colectivas o simbólicas que sean del caso, en términos de esta ley".

48 Art. 24: "La ley 975 de 2005 tendrá un nuevo artículo 23A, del siguiente tenor: 'Artículo $23 \mathrm{~A}$. Reparación integral. Con el fin de asegurar a las víctimas una reparación integral, la Unidad Administrativa Especial para la Atención y Reparación Integral a la Víctimas y/o la Unidad Administrativa Especial de Gestión de Restitución de Tierras Despojadas, según corresponda, adoptarán las medidas articuladas de rehabilitación, restitución, indemnización, satisfacción y garantías de no repetición, según corresponda por el hecho victimizante, de conformidad con el modelo de reparación contemplado en la Ley I 448 de 20 I I y sus normas complementarias".

49 Ley I448 de 20I I: "Artículo 25. Derecho a la reparación integral. Las víctimas tienen derecho a ser reparadas de manera adecuada, diferenciada, transformadora y efectiva por el daño que han sufrido como consecuencia de las violaciones de que trata el artículo $3 .{ }^{\circ}$ de la presente Ley. La reparación comprende las medidas de restitución, indemnización, rehabilitación, satisfacción y garantías de no repetición, en sus dimensiones individual, colectiva, material, moral y simbólica. Cada una de estas medidas será implementada a favor de la víctima dependiendo de la vulneración en sus derechos y las características del hecho victimizante".

50 Consejo de Estado, Las sentencias de unificación jurisprudencial y el mecanismo de extensión de la jurisprudencia, Bogotá, Imprenta Nacional, 20I4; igualmente Consejo de Estado, Sección Tercera, Unificación jurisprudencial. Perjuicios inmateriales. Perjuicio moral, perjuicios derivados de la violación de bienes constitucionales y convencionales, daño a la salud, Bogotá, Imprenta Nacional, 20I4. Dichos documentos se encuentran en la página web del Consejo de Estado. Sobre el último, de tipología de daños, lo referimos con la anotación ya realizada en el sentido de que no es lo mismo la tipología del daño que la reparación del mismo. 
dos las formas de reparación. De una parte, aquellas que sin discusión alguna son admitidas por la doctrina por ser de más larga tradición en la materia (A), y de otra, aquellas que son producto de las nuevas tendencias del derecho bajo la influencia notoria pero no exclusiva, como se verá, del discurso de los derechos humanos (B).

Según se analizará, habrán de integrarse al presente plan algunas de las maneras de reparar que han quedado vistas tanto en normas internacionales como nacionales. Por ejemplo, ¿en qué lugar se deben clasificar la rehabilitación, las garantías de no repetición, la petición de excusas, las ceremonias o aun la restitución? El traslape que pueda existir en el tema será objeto de explicación en cada una de las formas de reparar.

\section{A. Modos de reparación admitidos como tales sin discusión por la doctrina}

\section{A.I. La reparación pecuniaria}

22. Definición de reparación pecuniaria. La reparación pecuniaria es la "asignación de una suma de dinero, daños-intereses o indemnización delictual. Esta indemnización pecuniaria puede consistir tanto en un capital pagado en un solo contado, como en una renta" ${ }^{\mathrm{I}}$. Según Roujou DE BoubÉE, mediante una fórmula igualmente recogida por CoRMIER ${ }^{52}$, "la reparación pecuniaria procura a la víctima una suma de dinero que representa la conversión del daño en unidades monetarias"53. Estas últimas son, en palabras de CHApus, "otorgadas, ora en un solo contado (pago de un capital), lo que es más frecuente, ora (en ciertos casos de daños corporales) bajo la forma de una renta vitalicia o temporal, pagadera (por ejemplo) anualmente. Tal es la reparación llamada 'por equivalente" ${ }^{54}$. Al decir de la doctrina europea, "la reparación en valor consiste exclusivamente en el otorgamiento a la víctima de una indemnización pecuniaria, por oposición a la reparación in natura, que se relaciona con toda forma de reparación diferente al otorgamiento de una suma de dinero (restablecer las cosas al estado anterior, dar un bien equivalente a aquel destruido, condenar al pago de trabajos destinados a borrar el daño, publicar la decisión de condena)”55.

5 I J. Carbonnier, Droit civil. Les biens. Les obligations, vol. 2, París, puf, 2004, p. 2400.

52 CH. Cormier, Le préjudice en droit administratiffrançais. Étude sur la responsabilité extra-contractuelle des personnes publiques, París, LGDJ, BDP, t. 228, 2002, p. 4IO.

53 Roujou de Boubée, Essai sur la notion de réparation, cit., p. 262.

54 R. Chapus, Droit administratif général, t. I, I 5. a ed., París, Montchrestien, 200 I, p. I 233.

55 Ph. Pierre y F. Leduc, La réparation intégrale en Europe. Études comparatives des droits nationaux, Buselas, Larcier, 2012 , p. 78. 
23. Ilustración de la reparación pecuniaria en la acción de reparación directa y de controversias contractuales. Por tratarse de las acciones en las cuales lo normal son las condenas de tipo pecuniario, me limitaré a traer a colación unos pocos ejemplos dentro de los innumerables que podrían citarse.

Este sería el caso de la responsabilidad estatal de carácter objetivo derivada de la privación injusta de la libertad. Así pues, en sede de reparación directa, se encuentra la sentencia de la Sección Tercera del Consejo de Estado que condenó a la Nación a responder por los perjuicios materiales e inmateriales causados al actor, quien fue retenido injustamente por varios agentes de la Policía y permaneció en un calabozo por un lapso de ocho días ${ }^{5}$. Otro evento estudiado de modo recurrente bajo la lupa de la reparación directa corresponde a la afectación de la población civil provocada por la ocurrencia de atentados terroristas. El Consejo de Estado identifica en la falla del servicio el fundamento principal de la responsabilidad estatal en dicho caso ${ }^{57}$. No obstante, la Sección Tercera también se ha valido de la aplicación del daño especial $5^{8}$ y del riesgo excepcional59 como bases para estructurar la responsabilidad de la Nación. De todas formas, bajo cualquiera de los referidos títulos de imputación, la corporación ha condenado al Estado a reparar pecuniariamente los perjuicios tanto materiales como inmateriales sufridos por la población civil.

${ }_{5} 6$ En el referido pronunciamiento, el juez administrativo establece que "la responsabilidad patrimonial del Estado debe ser declarada en todos aquellos casos en los cuales se dicte sentencia penal absolutoria o su equivalente, porque el hecho no existió, el sindicado no lo cometió o la conducta no era constitutiva de hecho punible”. El Consejo de Estado ubica en el artículo 90 $\mathrm{CP}$ el fundamento de la decisión reparatoria y condena así a la Nación a pagar por los perjuicios morales y materiales sufridos por el actor. C.E., Sección III, 6 de abril de 20 I I, actores: Joaquín Castro Solís y otros, exp. 2 I 653.

57 C.E., Sección III, Subsección B, 26 de junio de 2014, actor: Inversiones La Sorpresa Limitada, exp. 26r6 I. En dicha providencia se condenó al Estado a responder pecuniariamente, a título de falla del servicio, por las averías provocadas a un restaurante por causa de un atentado de las farc en la ciudad de Medellín. La Sala exigió al municipio responder por los perjuicios materiales e inmateriales sufridos. Lo anterior, toda vez que el juez administrativo consideró probada la omisión de las autoridades municipales respecto a sus obligaciones funcionales frente a la seguridad de la zona.

$5^{8}$ Ver, por ejemplo, el caso de un empleado de una empresa transportadora quien murió en Puerto Rico (departamento del Caquetá) por motivo de una explosión provocada por las farc y dirigida contra las instalaciones de los despachos judiciales y de la estación de policía. En la providencia bajo estudio, la Sala consideró que el Estado había actuado dentro del marco de sus posibilidades y, por lo tanto, el título jurídico de imputación aplicable correspondía al daño especial. C.E., Sección III, 23 de agosto de 20I 2, actores: Hugo Giraldo Herrera y otros, exp. 24392 .

59 Este es el caso de la sentencia del 30 de enero de $20{ }_{3}$ de la Sección III, Subsección B, del Consejo de Estado, C.P.: Danilo Rojas Betancourth, exp. 22325, en donde la Nación es condenada a reparar el daño causado al inmueble de propiedad de una parroquia, consecuencia de un ataque de las FARC contra la comandancia de policía del municipio. La Sala aplica el fundamento del riesgo excepcional bajo el entendido de que el objetivo del ataque terrorista constituía un inmueble representativo de la administración, lo cual generó un riesgo inminente para la población civil. 
En cuanto a la acción de controversias contractuales, un típico ejemplo de la aplicación del referido medio de control corresponde al evento en el cual se declara el incumplimiento de la Nación respecto a un contrato de naturaleza estatal y, en consecuencia, se condena a la misma a reparar los daños ocasionados al extremo contractual cumplido. Tal es el caso de un contrato celebrado entre la Cámara de Representantes y una sociedad privada, cuyo objeto consistía en el levantamiento del inventario físico de los bienes de la entidad. No obstante, para cumplir con tal objeto era perentorio que la contratante suministrara el valor histórico de cada bien a la sociedad, obligación que incumplió, impidiendo que el contratista llevara a feliz término el acuerdo. Por lo anterior, la entidad pública fue condenada ${ }^{60}$.

24. La indemnización pecuniaria en las acciones de nulidad y restablecimiento del derecho. Tal como se expuso respecto de las acciones de reparación directa y de controversias contractuales, se presentan ahora algunos ejemplos en los que el Consejo de Estado condenó a la Nación a responder pecuniariamente por el daño causado en sede de nulidad y restablecimiento del derecho. Lo usual es que dicha condena se profiera luego de la anulación del acto administrativo, puesto que la jurisprudencia ha considerado que las condenas contra el Estado por actos administrativos legales se tramitan bajo la cuerda de la acción de reparación $\operatorname{directa}^{6}$.

Un evento típico de condena estatal configurada por la acción de nulidad y restablecimiento del derecho se deriva del juicio de legalidad respecto de los actos administrativos proferidos por la DiAn. Tal es el caso de la declaratoria de nulidad de las resoluciones de dicha entidad que impusieron la sanción de clausurar un establecimiento de comercio por tres días, habida consideración de que la entidad pública consideraba, de manera errada, que el actor tenía que facturar con un talonario numerado. Como consecuencia de la nulidad declarada, la DIAN fue obligada a indemnizar de forma pecuniaria al particular. Ya que en el caso concreto no había certeza sobre la cuantía de los perjuicios sufridos, el monto

60 C.E., Sección III, Subsección B, 30 de octubre de 2013 , actor: Auditorías, Consultorías y Revisorías Fiscales Aurea Ltda., exp. 27 I 95.

6I En cuanto a los actos administrativos legales que, "no obstante su 'licitud' o 'legitimidad', pueden entrañar algún daño antijurídico que comprometa la responsabilidad del Estado”, la vía procesal procedente para acudir a la jurisdicción contencioso administrativa corresponde a la acción de reparación directa. Frente a estos, el régimen de responsabilidad aplicable corresponde al daño especial. Para examinar la evolución de las diversas posturas del Consejo de Estado frente a dicha situación, ver C.E., Sección III, 8 de marzo de 2007, actor: Carlos Sammy López Mustafá, Auditorías, Consultorías y Revisorías Fiscales Aurea Ltda., exp. I642 I. A propósito del tema se pronuncia la sentencia del ig de febrero de 2004 del Consejo de Estado, Sección II, actor: Óscar Rosero De La Rosa, exp. 2402 7: "La Sala ha reconocido la viabilidad de la acción de reparación directa por los perjuicios causados por la expedición de un acto administrativo cuya legalidad no se discuta en el curso del proceso, puesto que se reconoce que el ejercicio de la función administrativa ajustado al ordenamiento jurídico puede generar un rompimiento del equilibrio de las cargas públicas que deben soportar todos los ciudadanos”. 
de la referida indemnización fue establecido de conformidad con la regla de la reparación integral ${ }^{62}$.

También es recurrente el empleo de la acción objeto de estudio en el ámbito del derecho laboral. A modo de ejemplo, se tiene el caso del exmagistrado de la Corte Suprema de Justicia que exigió, mediante acción de nulidad y restablecimiento del derecho, la diferencia (presentada desde la fecha de su vinculación hasta su retiro) entre las cesantías reconocidas a un congresista y aquellas devengadas por él. Con fundamento en el artículo i 6 de la Ley $4 \cdot{ }^{a}$ de i 992 , el cual establece la igualdad de la remuneración entre congresistas y magistrados de las Altas Cortes, la Sala declaró la nulidad de la resolución mediante la cual no se accedió a pagar la suma exigida por el actor y, a modo de reparación, condenó a la Nación a cancelar la diferencia adeudada ${ }^{63}$. En la misma línea se encuentran múltiples sentencias de las cuales me limito a citar solo algunas ${ }^{64}$. Resta

62 C.E., Sección IV, I 8 de marzo de 2004, actor: Álvaro Hernando Gama, exp. I 375 I. A propósito de la reparación integral, la sentencia establece: "En aras de garantizar la indemnización del daño causado, cuando no existe duda sobre su existencia y no hay certeza sobre la cuantía de los perjuicios, el juez debe aplicar la anterior norma. En consecuencia corresponde al juez fijar la indemnización integral y en equidad de los perjuicios causados en el proceso. Con base en lo anterior y reiterando que aparece acreditado que la oficina del actor fue clausurada por tres días, lo cual le impidió su ejercicio profesional por el mismo término, la Sala señalará como indemnización integral y en equidad la suma de dos salarios mínimos legales mensuales vigentes, con lo cual se le indemniza por todo concepto". En este sentido, ver también: C.E., Sección I, 7 de octubre de I999, actor: Aerolíneas Centrales de Colombia S.A.-Aces, exp. 5437: nulidad de un acto administrativo en el cual se le impuso multa a la aerolínea por haber descargado una mercancía sin -supuestamente- la autorización de la autoridad aduanera; C.E., Sección I, I 7 de agosto de 2000 , actor: Electronics y Telephone Corp. S.A., exp. 6042: nulidad de acto administrativo por supuestos errores en el manifiesto de carga que ya había sido corregido por el actor. Ya que la mercancía es decomisada por la Dian, la Sala obliga a la misma a pagar el monto correspondiente al avalúo de la mercancía decomisada; C.E., Sección I, 9 de noviembre de 2000, actor: Aerovías Nacionales de Colombia S.A. Avianca S.A., exp. 5808: nulidad de un acto administrativo que sancionaba a la empresa por supuestamente haber transportado más kilos de mercancía que los dichos en la guía máster de la importación. Debido a que la empresa es sancionada con una multa, a título de restablecimiento del derecho se reconoce el valor de la multa impuesta a la actora.

63 C.E., Sección II, 28 de noviembre de 20 I 2, actor: Carlos Ignacio Jaramillo, exp. I 734-I I.

64 C.E., Sala Plena, 28 de julio de I996, exp. S-638: nulidad de acto administrativo de personero que despide a secretaria en estado de embarazo, frente a lo cual, a más de la nulidad del acto, se dijo: "A título de restablecimiento del derecho, el Municipio de Cúcuta reintegrará a la actora al cargo de Abogado Auxiliar para la Vigilancia Administrativa de la Personería Municipal o a otro de igual o superior categoría y le reconocerá y pagará todos los sueldos y prestaciones dejados de devengar desde el retiro del servicio como consecuencia de la declaratoria de insubsistencia y hasta el día en que se efectúe el reintegro, con los aumentos o reajustes que haya tenido ese lapso"; C.E., Sección II, I6 de mayo de 2002, actor: Parménides Mondragón Delgado, exp. I659-0 I: nulidad de acto administrativo mediante el cual se declara insubsistente al actor en el cargo de asistente de presupuesto de la Industria Licorera de Caldas. La Sala ordenó el reintegro del actor; C.E., Sección II, I4 de septiembre de 2004, actor: Gloria Marina Vanegas, exp. NIJ-683: nulidad de acto administrativo mediante el cual se declara insubsistente a una abogada auxiliar para la vigilancia administrativa de la Personería Municipal; a título de restablecimiento del derecho se ordena reintegrar a la actora a su cargo. 
por anotar en este sentido que, en lo relacionado con la materia laboral, existen numerosos casos de condenas pecuniarias obtenidas gracias a acciones de grupo que, finalmente, son acciones también de índole pecuniaria que permiten, entre otras, reparaciones de dicho tipo ${ }^{65}$.

La lógica es entonces sencilla: para efectos de la reparación del daño, cuando se trata del daño pecuniario, da igual que el mismo sea causado por un acto o por un hecho administrativo, pues allí donde se haya causado un perjuicio al actor procede su indemnización. Como se verá más adelante, la anterior precisión no solo se da respecto de la reparación pecuniaria sino respecto de, por ejemplo, las reparaciones simbólicas. Lo importante en este momento es resaltar que dicho proceder es avalado por las diferentes secciones del Consejo de Estado cuando las pretensiones derivan de una acción de nulidad y restablecimiento del derecho (art. I 38 CPACA).

25. La indemnización pecuniaria en la acción popular. A pesar de que el objetivo de la acción popular es la protección de los derechos e intereses colectivos, y a pesar de que una de las hipótesis para que proceda permite que por su intermedio se logre "restituir las cosas a su estado anterior cuando fuere posible", es claro que cuando no es posible dicho restablecimiento se ha admitido la indemnización pecuniaria.

La hipótesis estudiada se puede ilustrar con el fallo de 9 de noviembre de 200I, que constató el irracional sacrificio de ro.000 animales salvajes (Hydrochoerus hydrochaeris, especie conocida en Colombia bajo el nombre de 'chigüiro'), cuya carne fue exportada gracias a una licencia ambiental y de exportación concedida sin tomar las debidas precauciones. Frente a esta situación, el Consejo de Estado ordenó "a las entidades demandadas implementar las medidas necesarias para reponer a la mayor brevedad posible la población de chigüiros que fue objeto de sacrificio. Para ello, deberán destinar los recursos económicos suficientes con el fin de implementar o apoyar inmediatamente proyectos o programas de gran envergadura para detener, controlar y de esta forma estabilizar el número de población de la especie afectada" ${ }^{66}$, garantizando así el retorno a la situación anterior a la transgresión del derecho colectivo. El principio es el mismo cuando se constata el estado de abandono en el cual se encuentra una iglesia colombiana que pertenece al patrimonio cultural de la Nación, cuya restauración se ordenó ${ }^{67}$. Se debe poner de relieve que el Estado, en estos casos, a pesar del hecho de que debe sufragar o costear las ayudas para reconstituir la especie o preservar el patrimonio cultural, no paga por equivalente pecuniario sino a través de la ejecución de obligaciones de hacer que deberá honrar con cargo al presupuesto,

65 Ver K. Bermúdez et al., Acciones de grupo en materia laboral, Bogotá, Universidad Externado de Colombia, Centro de Investigaciones Laborales, 2013.

66 C.E., Sección v, 9 de noviembre de 200I, actor: Rodolfo Puentes et al., exp. AP-I94.

67 C.E., Sección III, 20 de septiembre de 200 I, actor: Jaime Umaña Díaz, exp. AP- 25. 
con lo cual, de todas formas, se llega a la reparación pecuniaria. Se observa dicha lógica con los fallos adoptados para defender el goce del espacio público: una vez se constata la violación del derecho, el juez ordena que las autoridades, "dentro de los quince ( 15 ) días hábiles siguientes a la ejecutoria de esta providencia, expidan el acto administrativo que ordene la restitución del espacio público de modo que a más tardar en un (I) mes siguiente a su ejecutoria [se tomen las medidas para restablecer la integridad del espacio público, esto es,] se retire la reja que impide el tránsito peatonal por el callejón de la carrera $74 \mathrm{C}$ entre calles $7 \mathrm{~A}$ y $6 \mathrm{~B}$ "68. De igual forma, frente a un daño resultante de un pago indebido por un Ministerio a un particular en el marco de un contrato de transacción hecho en detrimento del Tesoro Público, y dejado sin efectos luego de una acción popular, ordenó a la persona privada reembolsar la suma debidamente actualizada ${ }^{6}$. Solo para insistir sobre la importancia y el potencial de la reparación pecuniaria de esta acción popular, se cita también el fallo de 15 de abril de $2004^{[70]}$ donde un actor popular impugnaba la declaración tributaria de una de las más grandes sociedades financieras. La demanda fue rechazada por falta de prueba, pero la posibilidad de que la hipótesis estudiada se vuelva a presentar queda abierta.

Finalmente, pero solo para afirmar que se considera que el Consejo de Estado incurrió en un error procesal, se trae a colación la acción impetrada por los habitantes de una comunidad, usuarios del servicio público de telefonía, con el fin de obtener la corrección de un error de facturación y el reembolso de sumas indebidamente pagadas. Luego de constatar que la facturación del servicio público se había establecido de manera ilegal, el juez ordenó "compensar las facturas de los usuarios del servicio" e incluir en la factura todos los elementos que justifiquen el cobro del servicio, así como permitir a los usuarios beneficiarse de un tratamiento sin discriminación tarifaria -cesación del daño hacia el futuro- ${ }^{7 \mathrm{I}}$. Si bien la lógica es la misma, se estima que dicha acción debió haberse tramitado por la acción de grupo o de clase, no por la popular.

26. La reparación pecuniaria en las acciones públicas de inconstitucionalidad. Consciente de que existe discusión acerca de si en las acciones que buscan la protección de la legalidad o constitucionalidad "abstracta" de las normas se puede considerar que la declaratoria de inconstitucionalidad o de nulidad genera una reparación económica, mi respuesta es positiva. Es decir, pienso que en más de una ocasión, cuando se declara la inconstitucionalidad de una ley o la ilegalidad de un acto administrativo general, la consecuencia inmediata es que el actor o un grupo de personas se benefician económicamente con dicha decisión. A más de

68 C.E., Sección I, I. ${ }^{\circ}$ de diciembre de 2005, exp. 25000-23-26-000-2004-00098-or, actor: Roberto Ramírez Rojas.

69 C.E., 3 I de mayo de 2002 , actor: Contraloría General de la República et al., exp. AP-300.

70 C.E., Sección III, I 5 de abril de 2004, actor: Fundación FicdisJ, exp. AP-2 I 36.

7 I C.E., Sección II, 28 de septiembre de 2000, actor: Judith Correa Luque, exp. AP-I I 7. 
los ejemplos que citaré a continuación para probar mi afirmación, quiero traer un argumento de índole práctica: muchos de los grandes litigios económicos donde se discute la validez "abstracta" de una norma se llevan a cabo por abogados litigantes pagados por empresas o personas que tienen un interés pecuniario directo en que la norma desaparezca del ordenamiento jurídico. Si ello es así, la pregunta que surge es la siguiente: ¿por qué una persona natural o jurídica habría de pagar a un abogado para que "tumbe" una norma de carácter general? En caso de que prospere la demanda, ¿el efecto automático no es de reparación económica? Veamos la respuesta afirmativa en ejemplos jurisprudenciales.

Tal es el caso de la sentencia C-I49 de i993, en la cual la Corte Constitucional declaró la inexequibilidad de los artículos I6, i 7 y i 8 de la Ley 6. a de I992, referentes a la obligación de las personas naturales y jurídicas con determinados ingresos a realizar inversiones forzosas en Bonos para Desarrollo Social y Seguridad Interna (вDSI). La corporación consideró que la norma no se ajustaba a la Carta Política por tratarse de una disposición tributaria de carácter retroactivo, y determinó que quienes se vieron obligados a pagar dicho impuesto sufrieron un daño, en vista de que el mismo afectó "situaciones o hechos que ya est[aban] fuera de su control y previsión". Ahora, puesto que al momento de proferir el fallo la mayor parte del tributo había sido recaudada, "con el objeto de realizar la justicia querida por el Constituyente volviendo las cosas al estado anterior al quebranto de los preceptos superiores y en busca de la prevalencia del derecho sustancial (artículo 228 C.N.), se orden[ó] al Ministerio de Hacienda y Crédito Público la inmediata devolución de las sumas pagadas por los contribuyentes". La Corte justificó su decisión argumentando que esta impedía el enriquecimiento sin causa del Estado y la consolidación de un perjuicio injustificado para los contribuyentes $^{72}$. En esta hipótesis la decisión de la Corte supuso automáticamente la reparación económica de quienes habían sido obligados a pagar el tributo.

Similar cosa ocurre con la famosa controversia surgida a partir del cobro de la Tasa Especial por Servicios Aduaneros (TESA), en virtud de que las disposiciones que la crearon fueron declaradas inexequibles por la Corte Constitucional en el año 200I ${ }^{[73]}$. Posteriormente a dicha sentencia, la sociedad Goodyear de Colombia S.A. acudió ante la jurisdicción contencioso administrativa y solicitó que se declarara patrimonialmente responsable a la Nación por la expedición y aplicación de los artículos abiertamente inexequibles que crearon la referida tasa. Así pues, la sociedad solicitó la devolución de las sumas pagadas por concepto

72 Corte Constitucional, C-I49 del 22 de abril de r993, actores: Mauricio Valenzuela Gruesso, Luis Carlos Gómez Jaramillo, María Cristina Ocampo de Herrán, Luis Guillermo Nieto Roa, exps. D-r 84, D-i 85, D-i 89 y D-r 94 (acumulados).

73 Corte Constitucional, C-922 del 29 de agosto de 200 I, actor: Álvaro Édgar Hernández, exp. D-3434. 
de la TESA. Con ocasión de lo expuesto, la Sala estableció que la expedición de una ley que luego es declarada inexequible corresponde a una falla en el servicio que genera un daño antijurídico. Este es un importante precedente en lo relativo a la responsabilidad del Estado legislador por proferir leyes que a la postre son declaradas inconstitucionales. Con fundamento en lo anterior, el Consejo de Estado condenó al Congreso a indemnizar pecuniariamente a la actora por los perjuicios materiales sufridos 74 . Nótese que la única diferencia con la sentencia C-r49 de r993 es que en esta la decisión de constitucionalidad ordenó la devolución de los tributos, en tanto que en la C-922 de 200 I fue gracias a la inexequibilidad declarada que se pudo hacer el cobro vía acción de reparación directa. Ello supone que aun en el caso en el cual en la sentencia de I993 no se hubiere ordenado directamente la devolución de los dineros, de todas formas hubieran podido ser reclamados en acción de reparación directa y, aún más, hoy en día en acción de grupo.

La sociedad Goodyear no fue la única en acudir ante la jurisdicción contencioso administrativa exigiendo el reconocimiento de los perjuicios derivados del recaudo de la TESA, declarada inexequible. En efecto, en abril de 2014 el Consejo de Estado declaró responsable a la Nación-Congreso de la República por la falla en el servicio en que incurrió al expedir los artículos mediante los que se creó la TESA y, en consecuencia, condenó a la Nación a devolver a la sociedad Laboratorios Wyeth "las sumas de dinero que la sociedad [...] pagó, durante el tiempo en que estuvo vigente en el ordenamiento jurídico, por concepto del tributo irregularmente creado"75. Los mismos hechos y consecuencias jurídicas se verificaron en la sentencia de i I de junio de 20 I 4 en la que el Consejo de Estado ordenó a la Nación pagar a la sociedad Promigas el dinero cancelado por esta a raíz de la $\mathrm{TESA}^{76}$. Si bien los casos citados parecen aislados, estos constituyen precedentes fundamentales para futuras acciones. Es lo que puede ocurrir con la reciente sentencia C-2 I 8 de $2015^{[77]}$, mediante la cual la Corte Constitucional declaró la inexequibilidad de la norma que amplía la base de la tasa por concepto de vigilancia en favor de la Superintendencia de Puertos y Transporte -contenida en la Ley I450 de 20 i i sobre el Plan Nacional de Desarrollo 2010-20i4-, en caso de que dichos tributos ya hubieren sido sufragados por quienes ahora se benefician de la declaratoria de inconstitucionalidad.

74 C.E., Sección III, Subsección C, 26 de marzo de 2014, actor: Goodyear de Colombia S.A., exp. 2874I.

75 C.E., Sección III, Subsección A, 9 de abril de 2014, actora: Sociedad Laboratorios Wyeth Inc., exp. 288I I.

76 C.E., Sección III, Subsección A, i r de junio de 2014, actora: Promigas Sociedad Anónima, exp. 26702 .

77 Corte Constitucional, C-2 I 8 del 22 de abril de 2015, actores: Álvaro Andrés Díaz Palacio, Mauricio Piñeros Perdomo y Valentina Escalante Giraldo, exp. D- I0445. 
En cuanto a la responsabilidad del Estado por el hecho del legislador por la expedición de leyes constitucionales, es perentorio hacer referencia a la sentencia de 25 de agosto de r 998 del Consejo de Estado. Aunque no se trate de un caso en el cual se pueda predicar que la condena al Estado proviene directamente de la ley constitucional, se quiere presentarla por cuanto es una consecuencia de la constitucionalidad de la norma que, sin embargo, produce un daño especial que repara el daño causado. Los hechos que dieron lugar a dicho pronunciamiento corresponden a la muerte de un ingeniero, quien fue atropellado por un vehículo conducido por un agente diplomático norteamericano. Como los familiares de la víctima no obtuvieron compensación alguna debido a que el agente gozaba de inmunidad diplomática en virtud de la Convención de Viena (aprobada mediante la Ley 6. ${ }^{a}$ de I972), estos acudieron ante la jurisdicción contencioso administrativa para obtener la reparación del daño. En la referida sentencia, el juez estableció que, pese a que el Estado es soberano en el manejo de sus relaciones internacionales, cuando del cumplimiento de un tratado internacional se deriva un perjuicio en cabeza de un particular, "la Nación Colombiana debe asumir las consecuencias patrimoniales derivadas del cumplimiento de sus obligaciones y respecto de las relaciones diplomáticas entre los Estados". En efecto, el Consejo de Estado condenó a los ministerios de Gobierno y de Relaciones Exteriores a responder por los perjuicios materiales e inmateriales sufridos por los familiares de la víctima ${ }^{7}$.

Si los efectos de una sentencia de inconstitucionalidad o aun de constitucionalidad pueden generar reparación automática de daños a personas determinadas que se encuentren en el área de influencia de los efectos de la decisión, también se observan ejemplos en los cuales, a la inversa, la sentencia de la Corte Constitucional puede producir efectos inmediatos sobre derechos subjetivos que ya habían sido 'adquiridos'. Es lo que ocurrió en la sentencia C-333 de 20 Io, en la cual la Corte consideró que la existencia de un 'mico' -casi 'orangután'- en el trámite de una ley violó la unidad de materia así como el principio de identidad flexible para favorecer a particulares al dar validez a unas conciliaciones que se hacían en materia tributaria, por lo cual ordenó que se declarara la inexequibilidad "desde la fecha de promulgación [...] de la ley". Ello significó que las conciliaciones realizadas quedaron anuladas por vía del control de constitucionalidad, con lo cual se produjeron directos efectos de reparación pecuniaria a favor del erario público. Es de anotar que es excepcional que la Corte profiera efectos ex tunc-hacia atrás-, pero aquí se imponía porque, como bien se dice en la sentencia,

78 C.E., Sala Plena, 25 de agosto de i 998, actor: Vitelvina Rojas Robles, exp. IJ-OOl. En el mismo sentido, ver: C.E., Sala Plena, 8 de septiembre de I998, actores: Leonor Judith Fandiño de Tarazona y otros, exp. IJ-002. 
... es necesario dar en este caso plena aplicación al clásico aforismo latino según el cual fraus omnia corrumpit (el fraude todo lo corrompe). Según ha quedado establecido, las normas acusadas fueron aprobadas en contravía de lo expresamente dispuesto por varias trascendentales disposiciones constitucionales, de allí que resulte imposible resguardar el interés de los beneficiarios de aquéllas, so pretexto de supuestas situaciones consolidadas o pretendidos derechos adquiridos, los cuales nunca pueden generarse en abierto desacato a los imperativos mandatos de la carta política 79 .

Sin que se incluya el tema del fraus omnia corrumpit, situación similar se presentó, si bien sin efectos hacia el pasado, en el famoso caso de las 'megapensiones', donde se ajustó a un tope máximo el valor de las mismas ${ }^{8 \circ}$, con repercusiones económicas respecto del grupo concernido de los pensionados.

Por otra parte, los referidos ejemplos no solo se presentan en sede de constitucionalidad, sino también cuando se declara la nulidad de un acto administrativo. Dicha idea es confirmada por el mismo Consejo de Estado, cuando afirma:

... la responsabilidad extracontractual no sólo puede provenir de hechos, omisiones, operaciones administrativas materiales, ocupación permanente o temporal por trabajos públicos, [sino que] también puede provenir de la declaración administrativa o judicial de la ilegalidad de los actos, revocatoria o nulidad, respectivamente; pues esas declaratorias reconocen la anomalía administrativa. Debe tenerse en cuenta que la revocatoria administrativa como expresión del control de legalidad de los actos propios de la Administración se manifiesta en un acto jurídico administrativo, el cual se presume legal; este acto puede ser examinado judicialmente a) o como consecuencia de la demanda de su nulidad (acción impugnatoria) b) o como consecuencia de la solicitud de responsabilidad extracontractual (acción reparatoria) fundada en el reconocimiento administrativo de su propia falta; este reconocimiento administrativo, se repite, como acto jurídico que es se presume legal y veraz ${ }^{8 \mathrm{I}}$.

79 Corte Constitucional, C-333 del I 2 de mayo de 20 ro.

80 Ver Corte Constitucional, $\mathrm{C}-25^{8}$ de 2013. Esta decisión fue confirmada ante la solicitud de nulidad impetrada por la Procuraduría General de la Nación, en el auto A-I80/15 del I3 de mayo del mismo año.

8I Auto que admite demanda con pretensión de reparación directa, en la que se pide la declaración de la responsabilidad estatal extracontractual como consecuencia de la revocatoria de una resolución administrativa mediante la cual se le indicaron a la demandante, como propietaria de un establecimiento de educación, unas tarifas para el cobro de las matrículas. C.E., Sección III, I9 de abril de 200I, actor: Fundación Centro Cultural Deportivo y Social del Meta, exp. 195I 7 . 
Ejemplo de lo anterior lo constituye la sentencia de 23 de febrero de $\left.20{ }_{2}{ }^{[82}\right]$ en la cual el juez administrativo condenó a la Nación, bajo el título de falla del servicio, a devolver a la sociedad Makro de Colombia S.A. las sumas pagadas por concepto de un tributo declarado previamente nulo por el Consejo de Estado. El juez supremo administrativo debate también esta materia al examinar el caso de una persona que solicitó la declaración de responsabilidad patrimonial de la Nación en virtud de la expedición defectuosa de un acto administrativo mediante el cual se le otorgó la licencia de construcción de una estación de servicio de venta de gasolina. Dicho acto fue anulado en sede judicial por la jurisdicción de lo contencioso administrativo. Este caso se diferencia de aquellos estudiados previamente, puesto que en esta ocasión el actor resultó beneficiado por el acto administrativo declarado nulo. En ese sentido, el daño se desencadenó a partir de la declaratoria de nulidad de la licencia. La Sala consideró que existió falla del servicio y, por lo tanto, declaró responsable al Estado por la pérdida de oportunidad sufrida por el demandante al no haber podido "continuar con los procedimientos administrativos que eventualmente le hubieren permitido poner en funcionamiento la Estación de Servicio cuya explotación económica tenía proyectada"83.

27. La indemnización pecuniaria en la acción de tutela. A pesar de que la acción de tutela no está concebida prioritariamente para indemnizar pecuniariamente ${ }^{84}$, sí existen numerosos casos en que ello ha ocurrido. A continuación se demostrará cómo la Corte Constitucional repara daños de toda índole mediante la condena pecuniaria.

Un ejemplo de esta forma de reparación por parte del juez constitucional corresponde a la sentencia T-629 de $20 \mathrm{IO}^{\left[{ }^{[8}\right]}$, mediante la cual la Corte reconoce la existencia de un contrato de trabajo entre un establecimiento y una trabajadora sexual. La sentencia se basa en el caso de una mujer que fue despedida del

82 C.E., Sección III, 23 de febrero de 201 2, actor: Makro de Colombia S.A., exp. 24.655.

83 C.E., Sección III, Subsección A, 2 de abril de 2013, actor: Luis Antonio Pantoja Ceballos, exp. 26427 .

84 Facultad que da el artículo 25 del Decreto 259I de I99I que dice: "Indemnizaciones y costas. Cuando el afectado no disponga de otro medio judicial, y la violación del derecho sea manifiesta y consecuencia de una acción clara e indiscutiblemente arbitraria, además de lo dispuesto en los dos artículos anteriores, en el fallo que conceda la tutela el juez de oficio, tiene la potestad de ordenar en abstracto la indemnización del daño emergente causado si ello fuere necesario para asegurar el goce efectivo del derecho así como el pago de las costas del proceso. La liquidación del mismo y de los demás perjuicios se hará ante la jurisdicción de lo contencioso administrativo o ante el juez competente, por el trámite incidental, dentro de los seis meses siguientes, para lo cual el juez que hubiere conocido de la tutela remitirá inmediatamente copia de toda la actuación". Sobre este tema ver mi trabajo "La acción de tutela y la responsabilidad extracontractual del Estado", en Homenaje a Fernando Hinestrosa. Treinta años de Rectorado. Liber Amicorum. Estudios y temas, t. 2, Bogotá, Universidad Externado de Colombia, I993, pp. 229276.

85 Corte Constitucional, T-629 del I 3 de agosto de 20 Io, actor: Sra. Lais, exp. T-23846 I I. 
establecimiento en el que prestaba servicios sexuales, sin permiso del inspector de trabajo, por motivo de su estado de embarazo. En virtud de lo anterior, la corporación concedió el amparo de los derechos fundamentales de la trabajadora y, a título de reparación del daño, ordenó a su empleador indemnizarla por haberla despedido injustificadamente y pagarle la licencia de maternidad a que tenía derecho. Más discutida fue la solicitud de restablecimiento del derecho, porque la Corte estimó que si bien debía indemnizar el incumplimiento del contrato realidad laboral, las normas internacionales se orientan a desincentivar el trabajo sexual.

Por otra parte, también resulta interesante el estudio de la sentencia T-o85 de $2009^{[86]}$, en la cual la Corte se pronuncia sobre la atención a la población desplazada, uno de los aspectos más dramáticos de la vida social colombiana. Dicha providencia resuelve tres acciones de tutela acumuladas contra la Presidencia de la República-Acción Social, que alegan la vulneración del derecho fundamental a la justa indemnización por el desplazamiento forzado del corregimiento de Bellavista, sufrido desde el mes de octubre de 200 I. Atendiendo a la obligación del Estado de satisfacer el derecho a la reparación de los accionantes, la Corte condena en abstracto a la agencia presidencial a pagar los perjuicios causados a los mismos.

Finalmente, otro ejemplo jurisprudencial de la forma de reparación bajo estudio corresponde a la sentencia T-222 de $2014^{[87]}$. En la misma, la Corte analiza tres procesos acumulados, cuyos supuestos fácticos coinciden, ya que todos los accionantes adquirieron créditos con entidades financieras, los cuales estaban respaldados por contratos de seguro. Dichas garantías operarían por muerte o pérdida de capacidad laboral en porcentaje mayor al 50\%. Efectivamente, los peticionarios fueron calificados con invalidez, y no obstante las aseguradoras se negaron a pagar las referidas pólizas. La corporación decide conceder la tutela de los derechos fundamentales al mínimo vital y a la vida digna de los accionantes y ordena a las aseguradoras pagar los saldos insolutos.

28. La dificultad de la reparación pecuniaria integral de los daños causados por el desplazamiento forzado en Colombia. Los principios que se acaban de dejar sentados no tocan un punto crucial para el futuro de nuestro país en el eventual

86 Corte Constitucional, T-०8 5 del I 6 de febrero de 2009, actores: Luis Francisco Orozco García, María de los Ángeles Brochero Bolaño, Alfonso Rafael Orozco Bolaño y María de los Ángeles Navarro Orozco; Yoleidy Yance Villa, y Roberto Antonio Yance Martínez y Yohemis Mercedes Villa Cantillo en su nombre y en representación de su hijo menor Roberto Carlos Yance Villa; y Osvaldo Martínez Arias y Martha Helena Meneses Roldán en su nombre y en representación de sus hijos Luis Javier, Alexander, Osvaldo Enrique, Leonardo y Leydis Milena Martínez, exps. T-2.050.591, T-2.056.396, T-2.056.402 (acumulados).

87 Corte Constitucional, T-222 del 2 de abril de 20I4, actores: Jesús Núñez Contreras en contra de Seguros de Vida ввva; José del Carmen Martínez Mejía en contra del Banco Davivienda y Compañía Seguros Bolívar S.A.; Argemiro Arzuaga Manjarrez en contra de Seguros de Vida Suramericana S.A. y Bancolombia S.A., exps. T-4I43382, T-4I4879I, T-4I 43384 (acumulados). 
-deseable- postconflicto que surgiría con la cesación de la lucha armada. No se quiere con lo anterior sostener que las reparaciones generadas por el conflicto dependan del postconflicto, pero sí se quiere afirmar que buena parte de la suerte del postconflicto se jugará en la manera como se repare a las víctimas. ¿Podrá el país pagar integralmente todos y cada uno de los daños padecidos por más de seis millones de víctimas? Es aquí donde se plantea la discusión de hasta qué punto un país que ha cometido graves y masivas violaciones a los derechos humanos, como lo es Colombia, podrá reparar íntegramente a las víctimas de las mismas. Las cifras del fenómeno son escalofriantes: el i i \% de la población colombiana es desplazada, y de ella el $63 \%$ es menor de 25 años; entre i 980 y 20 Io el I $5,4 \%$ -6,6 millones de hectáreas- del territorio nacional agropecuario fue despojado o tuvo que ser abandonado debido a factores de violencia; el valor total de la reparación por el fenómeno estudiado equivale a 80 billones de pesos para los daños materiales (lucro cesante y daño emergente) y a entre 27 y i64 para los daños inmateriales, lo cual suma entre IO7 y 244 billones de pesos (cifras de 20 I I $)^{88}$. Lo anterior lleva a afirmar a GARAY y VARGAS:

... se da cabida a un campo de discusión sobre la reparación en Colombia. Si se aceptara que el Estado colombiano no está en capacidad de reparar integralmente con el $100 \%$ a todas y cada una de las víctimas, entonces la sociedad y el Estado deben tomar la decisión comprometida sobre qué proporción del daño y en qué período de tiempo va a repararse a las víctimas. Esto es lo que se denomina la economía política de la reparación en Colombia: cuál es el esfuerzo consciente, decidido de una manera lo más ampliamente democrática posible, que la sociedad habrá de dedicar, en términos de recursos y riquezas del Estado, para reparar a las víctimas ${ }^{8}$.

Nótese que en esta hipótesis no está en discusión ni el daño ni la forma de reparación. Es sabido que en estos eventos la polémica que se presenta, como bien lo anotan los autores, no se refiere tanto a la posibilidad de que la responsabilidad civil juegue su papel tradicional de reparar daños, que se encontraría ciertamente desbordada, sino a la determinación de hasta dónde la sociedad podrá asumir su costo. Es en esta problemática en la que, entre otras, se presenta la validez real de la regla de la indemnización plena o integral del daño, por cuanto existe la discusión de su alcance y de su reemplazo por una indemnización menor donde se apliquen límites o topes indemnizatorios o reparaciones de tipo administrativo o determinadas por la ley; con lo cual se recuerda la gran discusión que se da frente a esta forma

88 L. J. Garay Salamanca y F. Vargas Valencia, Memoria y reparación: elementos para una justicia transicional pro víctima, Bogotá, Universidad Externado de Colombia, 20 1 2, pp. I 5 y i6.

89 Ibíd., p. 26. 
masiva de violación de derechos ${ }^{9}$. Se debe recordar que en derecho internacional existe un principio, arraigado desde el Tratado de Versalles, en virtud del cual:

... se puede deducir de los precedentes una norma autónoma que constituiría una excepción a la integralidad de la reparación en el caso específico de los daños de guerra. A más del peligro de que dicha excepción se pueda convertir en regla en una materia en la cual el juez internacional no es solicitado con frecuencia, esta práctica se justifica fácilmente por la equidad inherente a toda regla de derecho, asociada a una norma de ius cogens para algunos, que atenúa la regla de la reparación integral cuando ella crea el riesgo de privar a un pueblo de sus medios de sobrevivencia ${ }^{91}$.

También se debe anotar la tendencia de algunos sistemas jurídicos que, en materia de daños en general, busca que la reparación se haga por intermedio del sistema de seguridad social. Así,

... en materia de daños corporales, un sector de la doctrina francesa propende por la creación e implementación de un verdadero Derecho de accidentes corporales a la usanza del 'Accident Compensation Scheme' del derecho anglosajón, de acuerdo con el cual todo daño corporal (y sólo él) independientemente de su origen (doméstico, profesional, de transporte, vial, médico, producto de infracciones, del terrorismo; contractual o delictual) se indemnice bajo la modalidad à forfait (es decir, en forma global), pero de pleno derecho, por la Seguridad Social (la cual se encontraría autorizada, en aras de evitar la irresponsabilidad, para ejercer los recursos respectivos contra el autor del daño) $)^{92}$.

La discusión que se plantea, como se ha formulado en Colombia93, es hasta dónde la indemnización à forfait, o si se quiere administrativa, puede o no suplantar la reparación plena del daño.

\section{A.2. La reparación 'in natura'}

29. Definición de reparación 'in natura'. Cito una definición corriente aceptada por la doctrina: la reparación en especie o in natura es la "compensación del perjuicio

90 A este propósito, ver: De Greiff (ed.), The Handbook of Reparations, cit.

9i A. Kolliopoulos, La Commission d'Indemnisation des Nations Unies et le Droit de la Responsabilité Internationale, París, LGDJ, $200 \mathrm{I}$, p. 377.

92 M. Котеісн Кнатів, La reparación del daño como mecanismo de tutela de la persona. Del daño a la salud a los nuevos daños extrapatrimoniales, Bogotá, Universidad Externado de Colombia, 20 I 2, p. I 6 .

93 Ver en este sentido la referida sentencia C-r 80 de 2014 de la Corte Constitucional. 
por un beneficio diferente del dinero"94. Esta definición, basada en la ausencia de una condena pecuniaria al responsable, expresa una idea muy anclada en la doctrina:

... la reparación en especie responde verdaderamente a la función propia de la responsabilidad civil, según una fórmula probada por la jurisprudencia, tomada del decano Savatier, "es restablecer, tan exacto como sea posible, el equilibrio destruido por el daño y devolver a la víctima a la situación en la que se encontraría si el hecho dañino no se hubiere producido". La reparación en especie consiste, propiamente, en restablecer las cosas al estado anterior, restablecimiento; ella actúa sobre la lesión, sobre la base de la amenaza, sobre el daño. Es, por ejemplo, el tratamiento médico del daño corporal, es la restauración biológica del daño ecológico 95 .

En acuerdo con la anterior postura se puede agregar que "el responsable tiene obligación respecto de la víctima de hacer-reparar la cosa deteriorada, de publicar la decisión que lo condena por difamación, de transferir a la víctima la propiedad de un objeto análogo al objeto perdido o deteriorado" 96 . En consecuencia, esta forma de reparación es, en principio, aunque no necesariamente, "la forma más perfecta de reparar el perjuicio [y] consiste en dejar a la víctima en las mismas condiciones en que se encontraba antes de ocurrir el hecho dañoso. Una auténtica teoría de la responsabilidad civil debería tener como mira el alcance de tal manera de la reparación”97. En sentido muy similar afirma BARros Bourie:

... la restitución en naturaleza comprende un conjunto de pretensiones cuyo fin no es simplemente compensar económicamente al deudor por el daño sufrido, sino restituirlo a la condición efectiva en que se encontraba antes del hecho del demandado. El más elemental requisito para que proceda la restitución en naturaleza es que ella resulte posible. Si la víctima ha muerto o la cosa se ha destruido y no es posible su sustitución, la reparación en naturaleza está descartada y sólo procede la indemnización compensatoria ${ }^{9}$.

Roujou de Boubée, Essai sur la notion de réparation, cit., p. $27 \mathrm{I}$.

95 L. CADIET, "Les métamorphoses du préjudice", en Les métamorphoses de la responsabilité, Colloque commun aux Facultés de droit de l'Université de Montréal, de l'Université catholique de Nimègue et de l'Université de Poitiers, Sixièmes Journées René Savatier, Poitiers, I 5 y I 6 de mayo de I997, París, PUF, I997, p. 63.

96 Roujou de Boubée, Essai sur la notion de réparation, cit., p. 262.

97 J. Tamayo Jaramillo, Tratado de la responsabilidad civil, t. 2, Bogotá, Legis, 2007 , p. 676.

98 E. Barros Bourie, Tratado de responsabilidad extracontractual, Santiago, Jurídica de Chile, 2008, p. 877 . 
Finalmente, vale la pena precisar que, "de manera general, la naturalis restitutio tiene dos modalidades: la restitución jurídica que concierne a los actos jurídicos propiamente dichos y la restitución material que se relaciona con los hechos materiales que han sido la causa del perjuicio a un bien determinado"99. Pero en lo tocante a las órdenes que el juez pueda dar a la Administración para volver al status quo ante, hay muchos países que le limitan dicha posibilidad, basados en el principio de separación de poderes que supone que el juez no puede inmiscuirse en las funciones de la Administración. Así, por ejemplo, "en Francia no existe un régimen que tenga por objeto el restablecimiento o la reparación in natura [...] [y en Alemania] la reparación no se puede hacer in natura"

30. La similitud entre reparación 'in natura', restitución, rebabilitación y restablecimiento. Habida consideración de que muchas fuentes normativas tratan bajo diferentes términos el mismo fenómeno del retorno al status quo ante, como lo veremos, se quiere dejar sentado que dichos conceptos integran una forma de reparación que se caracteriza en todos los casos por volver a la víctima a la situación anterior al hecho dañino, imponiendo al responsable obligaciones de hacer o de no hacer que garantizan a la víctima una real reparación, por fuera de la condena pecuniaria. No en vano se afirma que "la restitución es la misma reparación in natura" "

3. El restablecimiento del derecho como forma por excelencia de reparación en el derecho internacional es reparación 'in natura'. En la ya citada Resolución 56/83 de 200 I se observa que el restablecimiento del derecho, o si se quiere la reparación in natura, es la forma más adecuada de retornar a la víctima a la situación anterior al hecho dañino. Afirma el artículo 35 ibídem que el Estado responsable de un hecho internacionalmente ilícito tiene "la obligación de proceder a la restitución consistente en el restablecimiento de la situación anterior a la comisión del hecho ilícito, siempre y cuando: a) no sea materialmente imposible, b) no imponga una carga fuera de toda proporción entre la ventaja que derivaría de la restitución en relación con la ventaja que se obtendría con la indemnización”.

Al decir del último relator de la mencionada resolución, la restitución corresponde al "restablecimiento hasta donde sea posible de la situación que existía

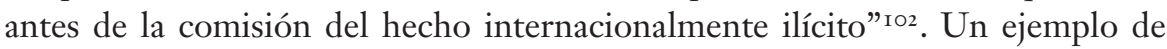
esta forma de reparación coincide con el famoso caso de la fábrica en Chorzow, controversia entre Alemania y Polonia resuelta por la Corte Permanente de Jus-

99 E. Stoppioni, La réparation dans le contentieux international de l'investissement. Contribution à l'étude de la restitutio in integrum, París, Pedone, 20I4, p. 73.

ioo A. Jacquemet-Gauché, La responsabilité de la puissance publique en France et en Allemagne, París, LGDJ, 2013 , pp. 347 y 355.

Io I López Díaz (coord.), Daño y reparación judicial en el ámbito de la Ley de Fusticia y Paz, cit., p. 237.

IO2 J. Crawford, Los artículos de la Comisión de Derecho Internacional sobre la Responsabilidad Internacional del Estado, Madrid, Dykinson, 2004, p. 257. 
ticia Internacional y originada en la indebida expropiación por parte de Polonia de una fábrica alemana. La Corte declaró a Polonia como Estado responsable y la obligó a restituir la empresa y, de no ser posible, a pagar su valor ${ }^{\mathrm{IO}}$. En lo que respecta a la indemnización, consagrada en el artículo 36 de la Resolución 56/83 de 200I, bajo esta forma de reparación "el Estado responsable de un hecho internacionalmente ilícito está obligado a indemnizar el daño causado por ese hecho en la medida en que dicho daño no sea reparado por la restitución"I04. En el ámbito del derecho internacional, en términos generales, existe en cabeza del Estado lesionado la facultad de elegir entre las diversas formas de reparación. Así, el Estado acreedor puede escoger, por ejemplo, la indemnización frente a la restitución. De nuevo el caso de la fábrica de Chorzow sirve como ejemplo para ilustrar esta idea, pues a raíz de dicha controversia Alemania prefirió la indemnización a la posibilidad de restitución ${ }^{105}{ }^{106}$.

Solo con la intención de insistir en la importancia de la restitución o restablecimiento en el derecho internacional, se traen a colación interesantes casos referidos en el libro del profesor SToppioni. Partiendo del principio general según el cual, "si la expropiación es ilícita, la restitución de la materialidad de la cosa es la consecuencia lógica de la violación del derecho internacional que, declarada por el árbitro, debe ser borrada por la devolución de la propiedad"107, el mencionado autor cita casos de interés para nuestros propósitos, como por ejemplo: la orden de devolución de una universidad que había sido ilícitamente expropiada a Hungría por el Estado checoslovaco (CPJI, Appel d'un jugement du Tribunal mixte arbitral húngaro-tchécoslovaque, I 5 de diciembre de I933, Serie A/B, n. ${ }^{\circ}$ 6r, I933); la orden de devolución de unas esculturas de un templo de Camboya que habían sido hurtadas por autoridades tailandesas (ciJ, Temple Préah Vihéar, Camboya vs. Tailandia, I 5 de junio de I962, cIJ Recueil i962, p. 6); la obligación de devolución de olivos, tierras, mejoras y otros bienes inmobiliarios por la edificación de un muro israelí en el territorio palestino ocupado

I03 Corte Permanente de Justicia Internacional (Permanent Court of International Justice), Caso de la fábrica en Chorzow, Alemania vs. Polonia, I922.

I04 Art. 36 Resolución 56/83 de 2001 .

I05 Art. 43 Resolución 56/83 de 2001: "Notificación de la reclamación por el Estado lesionado.

"I. El Estado lesionado que invoque la responsabilidad de otro Estado notificará su reclamación a ese Estado.

“2. El Estado lesionado podrá especificar, en particular:

“a) El comportamiento que debería observar el Estado responsable para poner fin al hecho ilícito, si ese hecho continúa;

"b) La forma que debería adoptar la reparación de conformidad con las disposiciones de la segunda parte".

IO6 CRawford, Los artículos de la Comisión de Derecho Internacional sobre la Responsabilidad Internacional del Estado, cit., p. 3 I 2.

Io7 Stoppioni, La réparation dans le contentieux international de l'investissement. Contribution à l'étude de la restitutio in integrum, cit., p. 8o. 
(cIJ, Conséquences juridiques de l'édification d'un mur en territoire palestinien occupé, concepto de 9 de julio de 2004, CIJ Recueil 2004, p. I98, n. ${ }^{\circ}$ I 53 ). En este sentido se afirmó: "La Corte Internacional de Justicia, en su concepto consultivo sobre las 'Consecuencias de la construcción de un muro en el territorio palestino ocupado', fundándose en el derecho consuetudinario en materia de reparación formulado en la sentencia Usine de Chorzow, consideró que el Estado de Israel tenía 'la obligación de reparar todos los daños causados a todas las personas físicas y morales concernidas', por los actos de desposesión y de destrucción constatados" Iо8.

Finalmente, la tercera forma de reparación -la segunda es la pecuniaria ya estudiada- corresponde a la satisfacción, la cual opera de manera excepcional únicamente cuando el perjuicio "no pued[e] ser reparado mediante restitución o indemnización” ${ }^{\circ}$. Dicha práctica es utilizada a menudo cuando se presenta un daño moral o no material ocasionado directamente por el Estado. Tal es el caso resuelto por la Corte Internacional de Justicia en el asunto Estrecho de Corfú, en el que la Corte, luego de declarar como ilícita una operación efectuada por la marina británica, declara que los actos de la marina violaron la soberanía de Albania. "Esta declaración [...] constituye de por sí una satisfacción apropiada" Io. Pero esta posición del derecho internacional donde de antaño se consideró que la mera publicación de la sentencia era por excelencia la forma de reparar, ha sido superada permitiendo peticiones de excusas, reconocimiento de la violación al derecho, y otras obligaciones a cargo de los Estados responsables que, de todas formas, "no debe[n] ser desproporcionada[s] respecto del perjuicio y no puede[n] tomar una forma humillante para el Estado responsable". Así, por ejemplo, la creación de una fiducia para mejorar las relaciones internacionales entre Nueva Zelanda y Francia ${ }^{\text {II }}$, o las excusas frente a violaciones de la soberanía, agresiones contra jefes de Estado, etc. La misma lógica, como se estudiará enseguida, se presenta en el derecho colombiano con peticiones de excusas, órdenes de hacer estatuas, institución de centros de memoria histórica, etc.

32. Las órdenes - 'injunctions'-constituyen obligaciones de reparación en especie. $\mathrm{Al}$ igual que ocurre en el derecho internacional, se observa que el objetivo de las injunctions es precisamente el de volver las cosas al status quo ante. Se recuerda, con Reiss, que "la reparación en especie busca una equivalencia entre la ventaja perdida y la ventaja en especie concedida a título de compensación. Este también

Io8 E. Guematcha, Les commissions vérité et les violations des droits de l'homme et du droit international bumanitaire, París, Pedone, 2014, p. 265.

Io9 Art. 37 Resolución 56/83 de 200 I.

I IO ICJ, Corfu Channel, Reports I949, p. 4, parr. 35. Caso citado por Crawford, Los artículos de la Comisión de Derecho Internacional sobre la Responsabilidad Internacional del Estado, cit., p. 279.

I I I Organización de Naciones Unidas, Recueil des sentences arbitrales, vol. xx, I990, p. 274, par. I 26 y I 27 . 
es el objetivo de la injunction, la cual reviste la forma de una orden dada por un tribunal a una persona determinada que, ora le prohíbe hacer o continuar haciendo cierto acto -probibitory injunction-, ora le ordena hacer cierto acto -mandatory injunction-" ${ }^{\text {I }}$. Si el objetivo de la reparación en especie y el de la orden -injunction- son idénticos, esta última se asemeja en consecuencia a una forma de reparación en especie, que se puede presentar tanto en una acción ordinaria como en una acción "preventiva”. Esto quiere decir que la orden es un modo de reparación en especie de daños consumados, perjuicios continuados y perjuicios ligados a la inminente amenaza de la lesión definitiva de un derecho. Todas las hipótesis suponen colocar a la víctima en la situación anterior al hecho dañino. La única diferencia estriba en el estado de avance del daño. La orden, como reparación en especie, se puede dar, como lo veremos, en todas las acciones.

33. La reparación 'in natura' puede tener variadas formas y no depende de la causa del daño. Como lo ilustra la doctrina, son variadas las formas bajo las cuales puede presentarse la reparación in natura, que pueden ser solicitadas en diversas acciones judiciales. Ciertamente, y con incidencia en el área objeto de estudio,

... la función de restablecer la situación anterior al daño no es desconocida del derecho administrativo. Si se toman las hipótesis de Mme. Roujou de Boubée, existe la supresión del daño por el procedimiento de las injunctions. Se encuentran además las formas de reparación in natura que permiten a la víctima encontrar la situación anterior al hecho dañino mejor de lo que puede ocurrir con la indemnización pecuniaria; [...] la función de restablecimiento juega un papel muy importante en el contencioso de los despidos ilegales de funcionarios: el juez procede al pago del salario no ganado. Pero la jurisprudencia va más lejos: el clásico fallo Rodière obliga a la administración a reconstituir la carrera del funcionario en las condiciones en las que habría estado si no se hubiere presentado la irregularidad ${ }^{\mathrm{II} 3}$.

Así como lo enuncia la autora francesa respecto del ejemplo del contencioso laboral, la misma lógica del restablecimiento como reparación in natura se aplica también en cualquier acción donde la causa del daño haya sido un acto administrativo. Al decir de García de EnTERría, a propósito de esta misma forma de reparación, el Tribunal puede adoptar

... cuantas medidas sean necesarias para el pleno restablecimiento de la situación jurídica individualizada en que se encontraba aquél [el lesionado] en el momento

I 2 L. ReIss, Le juge et le préjudice. Étude comparée des droits français et anglais, Presses universitaires d'Aix-Marseille, 2003 , p. 347.

i 3 J. Travard, La victime et l'évolution de la responsabilité administrative extracontractuelle, París, Mare\&Martin, 2013, p. 446. 
en que se dictó el acto recurrido productor de la lesión. Es cierto que, normalmente, si el acto anulado había causado una lesión económica evaluable, la restitución específica debía ser acompañada de una indemnización adicional que compensara la privación del derecho durante el tiempo en que el acto anulado vino ejecutándose, indemnización sin la cual no tendrá pleno restablecimiento la situación jurídica individualizada desconocida por el acto recurrido [...] el principio es general, como antes notamos; la indemnización complementaba aquí la reparación in natura, que era la sustancial ${ }^{\mathrm{I} 4}$.

34. ¿Toda reparación 'in natura' debe tener subrogado pecuniario? ¿Debe siempre el débito primario de una reparación 'in natura' convertirse en dinero mediante el subrogado pecuniario? Estas preguntas plantean una de las mayores discusiones teóricas que se pueden dar en el derecho de obligaciones ${ }^{115}$. Como es sabido, el daño genera obligación de reparar y dicha reparación, desde el punto de vista doctrinario, debe suponer una prestación que si bien no es necesariamente económica en tanto débito primario, sí lo debe ser en tanto débito secundario, esto es, convertirse en subrogado pecuniario para el momento de su ejecución. Es la posición del maestro Hinestrosa, que se acaba de citar, cuando en la referida obra (p. 286) afirma:

... si la obligación, como se vio atrás, se integra con el débito y la responsabilidad, y esta se manifiesta, en últimas, en la exigibilidad de una suma de dinero, equivalente pecuniario de la prestación (débito primario-débito secundario), resulta elemental e ineludible afirmar que no puede concebirse, siquiera, una obligación sino en cuanto existe la posibilidad cierta de satisfacción coactiva del acreedor, en últimas mediante el subrogado pecuniario. La prestación puede ser directamente monetaria y, no siéndolo, su patrimonialidad o su posibilidad de conversión en dinero, que son expresiones sinónimas, quiere decir, simplemente, que, así sea con dificultad, es factible tasar pecuniariamente el bien o el servicio en cuestión, esto es, establecer el equivalente pecuniario de la prestación.

En otros términos, en la relación acreedor-deudor por una prestación -lo que significa el concepto de obligación- se predica de la prestación su carácter económico ya sea como débito primario o como débito secundario.

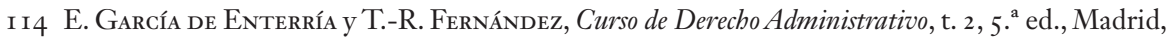
Civitas, I998, p. 407.

i 5 Ver en este sentido la magnífica obra de F. Hinestrosa, Tratado de Obligaciones. Concepto, estructura, vicisitudes, t. I, Bogotá, Universidad Externado de Colombia, 2002. Desde la definición de obligación (p. 55) plantea la discusión afirmando: "La pertenencia de la obligación al derecho patrimonial, la naturaleza, usualmente, pero no indefectiblemente, patrimonial del interés del acreedor y la exigencia de que la prestación sea patrimonial o, cuando menos, apreciable en dinero, han sido puntos debatidos larga y pugnazmente" (ibíd., nota r). Cita a continuación autores que han tratado el tema. 
La concepción descrita por la doctrina privatista genera consecuencias no despreciables también en derecho administrativo, que se apropia de una lógica que no le es propia, con independencia de la discusión que se debe generar también en derecho privado. Se es consciente de que una postura que considera la obligación de reparar también por fuera de lo pecuniario pudiera parecer que ataca el valioso principio del respeto a la libertad y a la dignidad humanas, tan bien expresado en el adagio inglés 'one can bring a borse to the fountain, but nobody can make him drink water' (es posible llevar el caballo a la fuente pero no hacerle beber el agua), o en el adagio latino 'nemo praecise cogi potest ad factum' (nadie puede ser obligado a hacer directamente alguna cosa).

Sin embargo, lejos está dicha postura de desconocer un principio filosófico tan decantado y tan trascendente para el desarrollo de la libertad humana. Por ello varias aclaraciones se imponen.

La primera consiste en afirmar que, de todas formas, se estima que los válidos pero discutibles argumentos del derecho privado para limitar la ejecución directa de una obligación in natura no son aplicables en derecho administrativo. Es cierto que en derecho privado, "en teoría, el recurso a la fuerza es posible, aun sin texto, cuando la medida no se considera contraria a la regla Nemo potest praecise cogi ad factum, que prohíbe el ejercicio de la presión física directa sobre el deudor o sobre los derechos fundamentales de la persona" ${ }^{16}$. Sin embargo, consideramos que estos adagios no pueden ser aplicados en derecho administrativo, donde precisamente el importante principio de legalidad no toma en cuenta la noción de libertad humana. El funcionario no actúa como persona sino como servidor público encargado de funciones precisas y determinadas, razón por la cual su libertad no está en juego. En consecuencia, en derecho administrativo existen hipótesis en las cuales el crédito primario debido por el Estado no puede trastocarse en equivalente pecuniario en el nivel de su ejecución, con lo que se resquebrajan los postulados del Código Civil. Para citar ejemplos, sería lo que ocurriría en el caso en que a una persona no se le expida un pasaporte. La obligación primaria no puede trastocarse en obligación secundaria, porque a la persona se le debe otorgar el pasaporte y no un subrogado pecuniario que dicho derecho pudiera verse atribuir arbitrariamente. Debe también tenerse en cuenta el artículo 27 del Decreto-Ley 259I de I99I, el cual enuncia las condiciones de aplicación de la decisión del juez de tutela. De esta manera, si la autoridad responsable no ejecuta la decisión judicial dentro de las 48 horas siguientes a su notificación, el juez debe dirigirse al superior jerárquico del funcionario en cuestión para ordenarle su ejecución. Si la Administración persiste en su comportamiento, además del recurso disciplinario que cabe contra el funcionario, “el juez,

I 6 C. Bloch, La cessation de l'illicite. Recherche sur une fonction inconnue en responsabilité civile extracontractuelle, tesis, Université Paul Cézanne-Aix-Marseille III, sustentada el 22 de noviembre de 2006 , no publicada, p. 503 . 
dentro de las 48 horas siguientes [...] tomará directamente todas las medidas para la completa ejecución de la decisión”, con lo cual se observa la autorización de la ley para que, por ejemplo, el juez expida el pasaporte.

La segunda aclaración supone recordar que ni siquiera la aplicación de los adagios citados tiene un carácter absoluto en derecho privado ${ }^{117}$, donde también existe "la realización de actos o de abstenciones como formas de reparar el daño causado" ${ }^{18}$. En efecto, si bien en derecho privado "las medidas que impiden a un actor su presentación de teatro constituirían una afrenta a su libertad individual, [los tribunales] no dudan, sin embargo, en ordenar el cierre de un establecimiento de comercio explotado en violación de una obligación de no hacer, o aun la expulsión manu militari de un inquilino que permanece abusivamente en los locales"II9. Similar situación se presenta en el procedimiento civil cuando el artículo 434 del Código General del Proceso, ante el incumplimiento en la suscripción de un documento, establece que si no se suscribe "en el término de tres (3) días, contados a partir de la notificación del mandamiento, el juez procederá a hacerlo en su nombre". En este sentido, afirma el profesor Bejarano que, "en esta forma de ejecución, si el deudor no cumple con la orden de pago, el juez lo sustituirá y firmará por él, de manera que nunca se presentará el fracaso de la pretensión por incumplimiento de lo ejecutado" ${ }^{20}$.

Partamos entonces de que en derecho administrativo los adagios referidos no tienen la misma implicación que en derecho privado, y, más precisamente, partamos de que se puede "hacer beber el agua al Estado". El no cumplimiento de una orden de hacer o de no hacer sin contenido pecuniario supondría el resquebrajamiento del Estado de Derecho y -de paso- el incumplimiento de una decisión judicial. En derecho internacional, tratándose por ejemplo de derechos humanos, se ha estimado -lo cual no es necesariamente la práctica actual- que la mera publicación de la sentencia de condena es en sí misma reparadora (sanción accesoria igualmente usada en materia penal). En el caso de la afrenta al honor, la condena no se expresa necesariamente por la sola sanción pecuniaria, pudiendo igualmente tomar la forma de una condena de hacer. Se podría tratar, por ejemplo, de la obligación de dar a conocer en el medio profesional o social de la víctima que las informaciones dadas carecían de veracidad y eran tan solo

i 7 J-L. Baudouin y P. Deslauriers, La responsabilité civile, 6. ${ }^{\mathrm{a}}$ ed., Quebec, Yvon Blais, 2003, p. 862: "A nuestro juicio, una distinción permite, a pesar de todo, reconciliar la preservación de las libertades individuales y la aplicación de la máxima nemo praecise potest cogi ad factum [...] La ejecución forzada, aunque sea evidentemente muy difícil por la potencialidad de resistencia del deudor, sigue siendo posible en el caso de obligaciones de hacer cuya ejecución no exija el cumplimiento por una determinada persona, es decir, cuando esta no puede ser ejecutada por uno de sus empleados, por uno de sus encargados o por uno de sus servidores, en el caso de una persona jurídica".

I 8 X. T. d. M. Neto, Dano moral coletivo, Sao Paulo, LTr, 2004, p. 85.

I 9 Roujou de Boubée, Essaie sur la notion de réparation, cit., p. I 74.

I 20 R. Bejarano, Procesos declarativos, ejecutivos y arbitrales, 5. ${ }^{a}$ ed., Bogotá, Temis, 20 I I, p. 54I. 
calumnias. Pensemos igualmente en el evento de una comunidad masacrada, cuya reparación puede también consistir en la presentación pública de excusas por parte del responsable. Para citar una decisión de la Corte Interamericana de Derechos Humanos de 200 I en dicho sentido: "El Estado de Guatemala bautizará una escuela con el nombre de los niños víctimas y colocará, en dicho centro, una placa con los nombres de [...]" г2 I , lo anterior con el objeto de "despertar la conciencia, evitar que tales hechos se repitan y conservar viva la memoria de las víctimas". Es evidente que las reparaciones acordadas en los casos citados son incompatibles con el equivalente pecuniario. No se podría afirmar que el Estado honra la obligación trastocando en dinero el bautizo de la escuela, la presentación de excusas, la no entrega del pasaporte, etc. Lo anterior permite afirmar que la Corte Interamericana "elaboró casi en su totalidad el amplio enfoque contemporáneo de medidas equitativas. Actualmente, las categorías generales de reparaciones no pecuniarias ordenadas por la Corte incluyen restitución y cesación, disculpas, monumentos, reformas legislativas, cursos de capacitación y programas de desarrollo comunitario" " 22 .

Los ejemplos citados demuestran que la postura clásica sobre la noción de patrimonio ha producido una influencia desafortunada en la responsabilidad civil, confundiendo entre derechos lesionados y maneras de reparar. Se olvida así que la lesión de todo derecho constituye daño y que los modos de reparación son un problema de creatividad jurídica que dependerá de la naturaleza del derecho lesionado. Además, la postura clásica desvertebra la coherencia entre los modos de reparación y los derechos a reparar. En efecto, si se trata de la lesión de un derecho pecuniario, la reparación debe tener la misma naturaleza. Igualmente, si se trata de la lesión de un derecho no pecuniario, lo mínimo sería abrir la posibilidad de que la reparación no fuera necesariamente pecuniaria y de que pudiera ejecutarse sin trastocarla en dinero. Ello porque la reparación in natura tiene hipótesis en las cuales no puede existir subrogado pecuniario, como se ratificará más adelante. Se garantizaría así una relación lógica entre los dos extremos, siguiendo el segundo - la reparación- la naturaleza del primero -el derecho lesionado-, es decir, lo accesorio siguiendo lo principal. Al contrario de esta postura, que aquí se defiende, la clásica que se analiza generó conflicto entre el daño como lesión de un derecho y su consecuencia lógica, la reparación, siendo que "todo daño no se traduce por una disminución de valores económicos" ${ }^{2} 3$. Era la única forma de permitir integrar al patrimonio la lesión de los derechos no pecuniarios. Esta evidencia olvidada por los profesores Aubry y Rau sigue reproduciéndose, por ejemplo, cuando se afirma en derecho administrativo francés que, "al concebirse la reparación solo bajo su forma pecuniaria, el perjuicio

I 2 I CiDH, Caso Niños de la calle (Caso Villagrán Morales y otros c/ Guatemala), 26 de mayo de 200 I. I22 Steiner y Uribe (eds.), Convención Americana sobre Derechos Humanos, cit., p. 270.

I 23 E. A. Zannoni, El daño en la responsabilidad civil, Buenos Aires, Astrea, I982, p. 4. 
debe ser evaluable en dinero y el juez debe poder cuantificarlo" ${ }^{24}$. La posición actual se puede entonces resumir diciendo que "tanto en derecho privado como en materia administrativa no hay vínculos obligacionales ajenos a los intereses pecuniarios" ${ }^{25}$. No se comparte, obviamente, tal posición.

35. Presentación de los ejemplos. Teniendo en cuenta lo afirmado en el parágrafo precedente, la forma de presentación de los ejemplos en los cuales se utiliza la reparación in natura dependerá de si tienen o no subrogado pecuniario. Está claro que en el evento en que lo tengan, el juez y la víctima deben abogar por que se logre la reparación in natura. No solo por cuanto en la mayoría de las ocasiones generará una reparación más eficiente, sino porque, dada la finalidad de determinadas acciones, sería ilógico permitir que la víctima adquiriera el valor del subrogado pecuniario.

36. La reparación 'in natura' con o sin equivalente pecuniario en el medio de control de la nulidad de restablecimiento del derecho en Colombia. El medio de control de nulidad y restablecimiento del derecho, consagrado en el artículo I 38 cPACA, corresponde a una pretensión de reparación o de responsabilidad estatal. Es así como dicho medio de control no se limita a examinar la legalidad de un acto administrativo, sino que, en palabras del profesor SANTofimio, la pretensión "tiene por objeto la protección directa de los derechos subjetivos de la persona amparados en una norma jurídica y desconocidos por el acto administrativo" ${ }^{26}$.

En este orden de ideas, el medio de control tiene una doble condición, pues, mediante el juicio de legalidad del acto que se ataca, busca el mantenimiento del orden jurídico, pero a su vez, por el restablecimiento del derecho, persigue la tutela efectiva de los derechos e intereses de los particulares sobre quienes recaen las consecuencias de los actos administrativos, sin que se excluya la indemnización pecuniaria de perjuicios ${ }^{127}$. De esta manera, en la práctica se combinan pretensiones declarativas con pretensiones condenatorias, y ello tanto desde el punto de vista del restablecimiento -in natura- como desde el punto de vista del pecuniario y aun de otras formas, como lo veremos.

En lo atinente a la condena mediante obligación de hacer con subrogado pecuniario se trae en primer término, por pertinente, la sentencia del Consejo de Estado del i 7 de agosto de 2000 , la cual declara la nulidad de un acto administrativo que ordena el decomiso de una mercancía por supuestos errores en

I24 J.-M. Joannìs, Le préjudice immateriel dans le contentieux de la responsabilité extracontractuelle de la puissance publique, tesis, Universidad de París 2, sustentada el 6 de abril de 1998, no publicada, p. 85.

I25 B. Plessix, L'utilisation du droit civil dans l'élaboration du droit administratif, París, PanthéonAssas, 2003 , p. 287.

i 26 J. O. Santofimio Gamboa, "Panorama general del derecho administrativo en Colombia", en $E l$ derecho administrativo iberoamericano, Granada, 2005, p. 248.

I 27 J. C. Expósito VéLez, "El Nuevo Código de Procedimiento Administrativo y de lo Contencioso Administrativo (Ley I.437 de 2.01 I)", Revista Digital de Derecho Administrativo n. ${ }^{\circ}$ 6, Universidad Externado de Colombia, julio-diciembre de 20 I I, pp. 25-45. 
el manifiesto de carga que ya habían sido corregidos por el actor. Dicha providencia exige a la DIAN, a título de restablecimiento del derecho, devolver la mercancía, en caso de que esta estuviese en poder de la autoridad aduanera. De lo contrario, le ordena pagar el monto correspondiente al avalúo de la mercancía decomisada $^{\text {I28 }}$. Igual ocurre cuando, como consecuencia de la confiscación de mercancías dentro del marco de procedimientos administrativos de lucha contra el contrabando, se retienen algunas así no hubiesen ingresado al país de manera ilegal. El juez ordena entonces la restitución de las mercancías ${ }^{129}$.

Ahora, a propósito de la condena mediante obligación de hacer sin equivalente pecuniario en el medio de control de la nulidad y de restablecimiento del derecho, se encuentran varios casos en materia de derecho laboral. Por ejemplo, cuando, a raíz de la declaratoria de nulidad del acto administrativo mediante el cual se le impone sanción de destitución a un policía, la Sala condena a la Policía Nacional a reintegrar al actor al cargo que ostentaba al momento de su retiro ${ }^{13^{\circ}}$. Otro caso lo constituye la declaratoria de nulidad de los actos administrativos que imponen a un inspector de trabajo una sanción disciplinaria de suspensión e inhabilidad especial. En dicha providencia el Consejo de Estado anuló los efectos de los referidos actos administrativos y, a título de restablecimiento del derecho, ordenó a la entidad demandada eliminar de la historia laboral del actor la anotación de la sanción ${ }^{\mathrm{I}}{ }^{\mathrm{I}}$.

En este punto se debe traer a colación el artículo $\mathrm{I} 89 \mathrm{CPACA}^{\mathrm{I} 32}$, que reitera la lógica que aquí se describe, en el sentido de dar prioridad al restablecimiento o reparación in natura y solo excepcionalmente permitir que se trueque en subrogado pecuniario.

37. La reparación 'in natura' con o sin equivalente pecuniario en la acción de tutela. Muchas de las obligaciones de hacer o de no hacer que se presentan en esta importante acción profieren órdenes de hacer o de no hacer que tienen equivalente pecuniario, y hay otras que no lo tienen.

I 28 C.E., Sección I, I 7 de agosto de 2000 , actor: Electronics y Telephone Corp. S.A., exp. 6042.

I 29 Ver C.E., Sección I, 4 de agosto de 2005, actor: Incelt Ltda., exp. 8 i 6; Sección I, 30 de junio de 2005, actor: Almacén Orient Ltda., exp. 7543.

I30 C.E., Sección II, I9 de mayo de 20 I I, actor: Remberto Enrique Corena, exp. 2 I 57 -05.

I 3 I C.E., Sección II, I 2 de abril de 20 I4, actor: Jorge Gutiérrez Sarmiento, exp. 0728-i 2.

I 32 Dice en lo pertinente el artículo: "En los procesos de nulidad y restablecimiento del derecho, la entidad demandada, dentro de los veinte (20) días hábiles siguientes a la notificación de la sentencia que resuelva definitivamente el proceso, cuando resulte imposible cumplir la orden de reintegro del demandante al cargo del cual fue desvinculado porque la entidad desapareció o porque el cargo fue suprimido y no existe en la entidad un cargo de la misma naturaleza y categoría del que desempeñaba en el momento de la desvinculación, podrá solicitar al juez de primera instancia la fijación de una indemnización compensatoria. De la solicitud se correrá traslado al demandante por el término de diez (ro) días, término durante el cual podrá oponerse y pedir pruebas o aceptar la suma estimada por la parte demandada al presentar la solicitud. En todo caso, la suma se fijará teniendo en cuenta los parámetros de la legislación laboral para el despido injusto y el auto que la señale sólo será susceptible de recurso de reposición”. 
Es posible encontrar innumerables ejemplos de acciones de tutela que, a pesar de presentarse bajo obligaciones de hacer o de no hacer-injunctions-, podrían tener un claro subrogado pecuniario. Es lo que ocurre, por ejemplo, con las reparaciones en materia de salud. Tal es el caso del hombre diagnosticado con una grave enfermedad que requiere de una silla de ruedas para movilizarse, al igual que de implementos de aseo como pañales desechables de adulto, crema humectante y toallas húmedas. En virtud de lo anterior, la Corte obliga a la EPS del actor a entregarle los elementos requeridos a causa de su patología ${ }^{\mathrm{I} 33}$. El mismo ejemplo se verifica en el caso en el cual la Corte obliga a ASMET Salud a entregar a una paciente, diagnosticada con cáncer de tiroides, los medicamentos y el suplemento alimenticio formulados por su médico ${ }^{\mathrm{I}} 34$. Finalmente, encontramos la sentencia T-650 de 20I4, en la cual se condena a la EPS Sanitas a realizar una valoración médica a una menor que se encuentra en situación de discapacidad. Lo anterior, con el fin de determinar los cuidados médicos e incluso la educación especial requeridos por la niña, los cuales eventualmente deberán ser costeados por la $\mathrm{EPS}^{\mathrm{I}} 35$.

Si bien es habitual encontrar esta forma de reparación por parte del juez constitucional al tutelar el derecho a la salud y a la vida, dicha reparación no se limita a este ámbito. Este es el caso de una mujer desplazada por la violencia, quien no tiene un lugar donde vivir y acude a la Corte para que se le tutelen sus derechos fundamentales. En consecuencia, la corporación ordena al municipio de Arauca ofrecerle un albergue temporal a la actora ${ }^{136}$.

Todos los casos presentados constituyen ejemplos de reparación in natura con equivalente pecuniario, puesto que el daño podría ser reparado mediante una obligación de hacer o por medio del subrogado pecuniario correspondiente, según el costo de los bienes y servicios ordenados. Sin embargo, se estima que por la naturaleza de la acción es conveniente conservar la orden de hacer o de no hacer, porque con ella se garantiza de mejor manera la protección del derecho constitucional fundamental lesionado. Piénsese en lo que podría ocurrir si se otorgara una suma de dinero como subrogado pecuniario a la reparación in natura: ¿tendría el lesionado el mismo cubrimiento para salir adelante en su situación? Se cree que no. Es lo que ocurre en el evento de que haya una amenaza seria sobre la vida de una persona, concretada por el envío a su domicilio de ataúdes como

I33 Corte Constitucional, T-13 I del 27 de marzo de 2015, exps. T-4.575.59I, T-4.576.906, $\mathrm{T}-4.577 .367, \mathrm{~T}-4.578 .486, \mathrm{~T}-4.579 .686, \mathrm{~T}-4.579 .727, \mathrm{~T}-4.579 .808, \mathrm{~T}-4.582 .829, \mathrm{~T}-4.5^{8} 3 . \mathrm{I} 34$, $\mathrm{T}-4.585 .625, \mathrm{~T}-4.587 .077, \mathrm{~T}-4.587 .203, \mathrm{~T}-4.588 .076, \mathrm{~T}-4.592 .778, \mathrm{~T}-4.596 .074, \mathrm{~T}-4.599 .0 \mathrm{I} 6$ (acumulados).

I34 Corte Constitucional, T-239 del 30 de abril de 20 I 5, actor: Pedro López Baca, exp. T-4.70 r.494.

I35 Corte Constitucional, T-650 del 4 de septiembre de 20I4, actora: Ella Judith Medrano Escandón, exp. T-4.343.418.

I36 Corte Constitucional, T-606 del i de agosto de 20 I I, actora: Eulalia Fonseca Velandia, exp. T-296r 889 . 
señal de advertencia y de cartas intimidatorias suscritas por grupos al margen de la ley, caso en el cual el juez ordena proteger al demandante ${ }^{\mathrm{I}} 37$. También sería el caso en el cual el juez de tutela protege la vida digna de una persona al ordenar que sea abastecida de pañales: aunque es obvio que los pañales tienen un valor en metálico, no sería conveniente ordenar el subrogado pecuniario, que haría perder la función social y constitucional de la reparación. Si bien se podría aceptar que, en teoría, cabría otorgar una suma de dinero para que la persona se provea sus guardaespaldas, ello violentaría la naturaleza de la acción y generaría el riesgo de que el dinero otorgado no sea utilizado para la prestación primaria que debe el deudor. La posición que aquí se toma es confirmada por el artículo $88 \mathrm{CP}$, cuando en su inciso segundo establece que "la protección consistirá en una orden para que aquél respecto de quien se solicita la tutela, actúe o se abstenga de hacerlo”, sin que se incluya como forma natural de la reparación el subrogado pecuniario.

También, lo cual es usual y lógico en esta acción, se encuentran múltiples casos en los que, aun si se quisiera, no puede haber subrogado pecuniario. Un ejemplo de este supuesto lo representa el caso resuelto por la Corte Constitucional en el que una madre invidente y de escasos recursos interpone acción de tutela en contra del ICBF, argumentando que tal entidad había desconocido su derecho a la familia, así como los derechos de su hija menor, pues había sustraído a esta última de su custodia y cuidado. La corporación decide amparar tanto el derecho de la niña a tener una familia y no ser separada de ella, como los derechos fundamentales de la madre. Así pues, además de que se le otorga la custodia de su hija, a la mujer invidente se le proporciona el apoyo estatal requerido por su condición. En este orden de ideas, en el referido ejemplo, la única forma de tutelar el derecho a la familia de la madre y de la menor correspondía a la reparación in natura otorgando todos los medios para el reintegro de la familia ${ }^{13}$. Igualmente, en el caso de varios estudiantes que fueron expulsados del colegio mediante una decisión que vulneró su derecho fundamental al debido proceso, sus padres accionantes solicitaron la orden de renovación de la matrícula de los menores. Por lo tanto, la única forma de reparar el daño sufrido por los estudiantes consistía en la reparación in natura. En efecto, luego de evaluar los supuestos fácticos y jurídicos, la Corte estableció que, en caso de que los menores quisieran regresar al colegio, este no podría negarse a matricularlos. Además, ordenó a la Secretaría de Educación del municipio que, en el evento en que los menores no quisieran regresar a la institución educativa, se les mantuviera el cupo en los colegios en donde se encontraban estudiando provisionalmente, o en otro establecimiento educativo diferente ${ }^{\mathrm{I} 39}$. Similar acontece en el evento en

I 37 Corte Constitucional, T-525 del i 8 de septiembre de I992, actor: Darío Antonio Mejía.

I 38 Corte Constitucional, T-397 del 29 de abril de 2004, exp. T-780760.

I39 Corte Constitucional, T-9i7 del 9 de noviembre de 2006, exps. T-г3192 I8, T-г322747, T-I 323408 y T-I 330627 . 
el cual se ordena la suspensión de una licencia de construcción de una carretera que atravesaba el territorio de una población indígena, en razón de la falta de consulta a la comunidad y de la ausencia de un permiso medioambiental ${ }^{140}$. Son hipótesis, se reitera, donde no se puede convertir en dinero la obligación reparadora ordenada por el juez.

38. La reparación 'in natura' con o sin equivalente pecuniario en la acción de reparación directa. A pesar de que usualmente la acción de reparación directa lleva a condenas de tipo pecuniario, no es extraño observar que bajo su cuerda también se pronuncian condenas de reparación in natura. Es el caso, por ejemplo, de la sentencia de 4 de septiembre de 2003 en donde, a raíz de un desalojo ilegal de un vendedor ambulante al que le dañaron sus mercancías, se obligó a "entregarle los siguientes bienes -que serán de la mejor calidad-, en las cantidades que a continuación se indican: I 6 medias botellas de miel de abeja, I 2 manos de banano, 29 paquetes de naranjas, 5 piñas, 96 manzanas [...] y I machete con cubierta" ${ }^{14}$. El mismo razonamiento es aplicado en un caso en el que el juez ordena al servicio de aduana devolver a la víctima, en la medida de lo posible, 574 calculadoras confiscadas de manera ilegal, que habían sido retenidas mediante una vía de he$\mathrm{cho}^{\mathrm{I} 4^{2}}$.

En un inhabitual pero interesante fallo, se condenó al Estado a una obligación de 'hacer' como consecuencia de una falla del servicio, dentro del marco del reclutamiento y de la prestación del servicio militar de una persona cuya incapacidad médica se agravó durante la prestación del servicio. El fallo afirmó: "Para la Sala la condena así impuesta, que implica en el fondo una obligación de dar un suma de dinero (el valor del tratamiento médico adecuado hasta la total recuperación del paciente o hasta la mejoría posible) deberá reemplazarse por una obligación de hacer, o sea la prestación del tratamiento médico integral hasta lograr el objetivo propuesto"I43. Años más tarde el Consejo de Estado colombiano confirmó esta solución ${ }^{\mathrm{I} 44}$.

En los eventos anteriores bien podría la condena tener un equivalente pecuniario, pero se estima que, al igual que se afirmó respecto de la acción de tutela, debe primar la reparación in natura porque, además de lo ya dicho, tradicionalmente se ha considerado que es la forma por excelencia de reparación.

Finalmente, respecto de condenas in natura que no tengan subrogado pecuniario, se encuentran todas aquellas, cada vez más usuales, en las cuales se

I 40 Corte Constitucional, T-428 del 24 de junio de 1992.

I4I C.E., Sección III, 4 de septiembre de 2003, actor: Pedro López Baca, exp. I 3320 (3828), extraído de Tesauro de Responsabilidad Extracontractual del Estado, cit., p. I 78, t. I.

I42 C.E., Sección III, 27 de marzo de I992, actor: Ramón Zuluaga Noreña, exp. 6885.

I43 C.E., Sección III, I 3 de diciembre de I995, actor: Gladys Rodríguez, exp. I0677.

I44 C.E., Sección III, 29 de enero de 2004, actor: Mery Teresa Colmenares Tovar et al., exp. I 8273: orden de entregar los medicamentos necesarios a causa de una contaminación con el virus del sida. 
ordenan medidas de satisfacción como lo son las excusas públicas, etc., que serán vistas en el siguiente acápite.

39. La reparación 'in natura' con o sin equivalente pecuniario en la acción popular. $\mathrm{Al}$ igual que ocurre en los medios de control anteriormente relacionados, en la acción popular también existen múltiples condenas de reparación in natura o restitutoria. Aún más, la lógica de dicha acción debe ser la de dar prevalencia a esta forma de reparación, precisamente porque su objetivo se satisface muy excepcionalmente por medio del dinero.

A propósito de las condenas al Estado en las que se ordena la reparación in natura con equivalente pecuniario, se tiene el ejemplo de la sentencia de 6 de marzo de 2013 en la que se discutió la apropiación, por parte de la Compañía Hotelera Cartagena de Indias S.A., de algunas zonas de playa y bajamar. Al final se condenó a dicha sociedad comercial a adquirir un terreno de la misma extensión ocupada para construir en él un parque destinado al uso y goce de toda la comunidad ${ }^{\mathrm{I}} 45$. Otro caso se dio en el barrio Granada de la ciudad de Cali, donde las redes de energía eléctrica y de telefonía se encontraban adosadas a las fachadas de las viviendas. Con el fin de proteger los derechos colectivos de los habitantes del sector, la Sala ordenó a las Empresas Municipales de Cali-EmcaLi EICE ESP construir redes subterráneas para la prestación de los servicios públicos domiciliarios $^{\mathrm{I} 46}$.

Ahora, con respecto a la reparación in natura sin equivalente pecuniario, un ejemplo lo constituye la sentencia de 6 de septiembre de 20 r 2 en la cual la Procuraduría General de la Nación solicitó la protección, entre otros, del derecho a un ambiente sano en cuanto a la prohibición de la pesca de tiburones en el archipiélago de San Andrés, Providencia y Santa Catalina. Finalmente, se condenó a los ministerios de Ambiente y de Agricultura a realizar una investigación científica para diseñar métodos de pesca aptos para evitar la caza indiscriminada de tiburones, así como a la expedición de un acto administrativo que oficializara la implementación del Plan de Acción Nacional para la Conservación y Manejo de Tiburones, Rayas y Quimeras ${ }^{\mathrm{I}}{ }^{7}$. La misma situación se verificó a raíz del irregular otorgamiento de licencias de construcción en el bosque de los Cerros Orientales de Bogotá, el cual fue declarado como área de reserva forestal. En aras de amparar el goce de un ambiente sano, la Sala impuso al Estado una

I 45 C.E., Sección III, Subsección C, 6 de marzo de 2013, actor: Norberto Gari García, exp. API300I 233 I00020010005 I OI.

I46 C.E., Sección III, Subsección B, 20 de febrero de 20I4, actor: Andrés Felipe Ramírez Gallego, exp. AP-7600 I-23-3 I-000-2003-00002-0 I.

I47 C.E., Sección I, 6 de septiembre de 20I3, actor: Procuraduría Judicial II Ambiental y Agraria de San Andrés, Providencia y Santa Catalina, exp. 8800 I-23-3 I-000-20 I I-00009-0 I (AP). 
obligación de no hacer correspondiente a negar la concesión de nuevas licencias que permitieran el desarrollo urbanístico en la reserva forestal ${ }^{14}{ }^{8}$.

Igualmente se puede citar, aunque en mi conocimiento no haya sido objeto de una sentencia judicial, el caso de la masacre y violación masiva de derechos humanos de la población campesina del Carare, frente a la cual, "ante este cuadro de afectaciones, instituciones como el ІсвF han desarrollado el programa de rehabilitación psico-social en procura de curar los miedos de la población afectada, sin que éste haya sido suficiente, por lo cual se propone el diseño por parte de expertos de una estrategia de rehabilitación psico-social" ${ }^{449}$. Este tipo de eventos, tristemente reiterativos en nuestra historia nacional, da lugar a muchas condenas que protegen derechos colectivos que, aunque pueden ser objeto de otras intervenciones judiciales - $\mathrm{CIDH}$, justicia penal, etc.-, también podrían presentarse por intermedio de las acciones populares, siempre y cuando en estas no haya peticiones de derechos individuales divisibles. Muchas de las reparaciones que se presentan en masacres protegen derechos colectivos como el de la seguridad pública, expresamente protegido por el artículo $88 \mathrm{CP}$ y por la Ley 472 de 1998.

\section{B. Los medios de reparación discutidos y los novedosos}

40. Presentación del tema. El título del presente literal y los desarrollos que le siguen parten de una idea general del derecho de daños: en la larga historia de la responsabilidad civil $^{15}$, ante el fortalecimiento del discurso de los derechos humanos y de la dignidad humana, las nociones clásicas de reparación se han expandido. Ello es lo que ocurre con los conceptos de satisfacción, rehabilitación, garantías de no repetición, etc., que si bien se pueden considerar en la tradicional reparación in natura, como se ha visto, ameritan un desarrollo especial para darles la relevancia que merecen, lo cual se hará en el punto B.2 de este acápite. Pero, a más de resaltar estas expresiones novedosas y democráticas del derecho

I48 C.E., Sala Plena de lo Contencioso Administrativo, 5 de noviembre de 20r3, actor: Sonia Andrea Ramírez Lamy, exp. AP-2 5000-23-25-000-2005-00662-03.

I49 G. SÁnchez Gómez (coord.), El orden desarmado. La resistencia de la Asociación de Trabajadores Campesinos del Carare (ATCC), Informe del Grupo de Memoria Histórica, Bogotá, Taurus y Fundación Semana, 201 I, p. $45^{2}$.

I 50 Permítase este dato: la Ley del Talión, conocida universalmente bajo la frase "ojo por ojo, diente por diente", es una de las principales y primeras fuentes históricas de la responsabilidad. Dicha regla, en apariencia inhumana por su crueldad, fue un paso definitivo y revolucionario en la historia de la humanidad, pues introdujo la justicia retributiva basada en la reciprocidad, bajo la cual se limitaba la venganza. Antes de dicha ley la humanidad se basaba en principios que podrían traducirse como "ojo por vida, diente por cuerpo", o algo similar. Esta ley se encuentra en muchos textos antiguos, como el Código de Hammurabi, del año i 728 a.C., en el libro Éxodo del Antiguo Testamento (2 I:23-25), etc. Por lo demás, la palabra Talión viene del latín talis o tale que significa idéntico o semejante, lo cual se utiliza en castellano con la palabra 'tal', que se usa en expresiones como 'tal cual', 'tal y como', etc. 
de daños, vale la pena plantear la discusión sobre si la cesación del ilícito es o no una medida reparadora, lo cual se estudiará en seguida en el punto B.I.

\section{B.r. ¿Es la cesación del ilícito una forma de reparación?}

4I. Definición de cesación del ilícito. Como se verá en el parágrafo siguiente, la cesación del ilícito ha sido fuente de polémicas en la doctrina jurídica. Ello porque en la teoría de la responsabilidad civil, según se ha dicho, se ha partido de que lo que se repara son lesiones ya consumadas de derechos, no daños que aún no se presentan como lesión definitiva o que se presentan simplemente como alteración del goce pacífico de tales derechos. Puesto que esta idea ya está tratada en el presente escrito, baste por ahora definir en qué consiste la figura en estudio. Según la doctrinante BacACHE-GiBeiLi,

... trátese de la destrucción de una construcción, del sellamiento de un establecimiento de comercio o de la prohibición de la venta de una obra, el objeto de la medida es suprimir la situación de hecho imputable al responsable, que se encuentra en el origen del daño sufrido por la víctima. En ello, la medida ordenada consiste en restablecer la situación anterior al daño. La especificidad de estas condenas in natura atribuiría a la responsabilidad civil una función de 'restablecimiento', al lado de su función indemnizatoria. Sin ir hasta la consagración de dicha diversificación de funciones, conviene al menos admitir la extensión del rol tradicional de la reparación, en la medida en que la reparación integral del daño continuado supone necesariamente la supresión de la situación fáctica que se encuentra en su fuente, dicho de otra manera, el restablecimiento de la situación anterior ${ }^{\mathrm{I}} 5^{\mathrm{I}}$.

Bajo esta concepción se puede admitir que la cesación del ilícito supone suprimir el daño continuado, lo cual coincide con nuestra postura, haciendo la aclaración de que, a diferencia de la mayoría de la doctrina y aun de la precitada autora, lo que se debe entender, como hemos insistido, es que el daño inicia desde el momento en que se altera el goce pacífico del derecho. Se reitera: el no daño consiste en el goce pacífico del derecho. De la alteración de dicho goce pacífico en adelante hay daño, y lo único que cambia es su grado de evolución. Por tanto, la cesación del ilícito operará siempre respecto de un daño continuado, que se presenta durante la alteración del goce pacífico sin que haya iniciado la lesión definitiva del derecho, o cuando esta ya ha tenido inicio pero no ha culminado, caso en el cual se presenta un daño continuado de lesión definitiva que aún no se ha consumado por completo.

I5 I M. Bacache-Gibeili, Droit civil, t. v, Les obligations. La responsabilité civile extracontractuelle, París, Economica, 2007, p. 5 I 5. 
Es por ello que "la cualificación de cesación del ilícito es necesaria específicamente para comprender correctamente reparaciones diferentes a la monetaria, así como la dimensión no exclusivamente indemnizatoria de la responsabilidad civil" ${ }^{52}$. Si se quiere ser más sutil, con algunas salvedades sería posible compartir la posición del precitado autor cuando afirma:

... se puede concluir que al lado de las medidas de anticipación del daño existen medidas de cesación del hecho generador. Las medidas de cesación se decretan durante la realización del hecho generador, contrario a las medidas de anticipación, que se pronuncian antes de que el hecho dañino se produzca. Las medidas de anticipación y de cesación concurren en el conjunto de la prevención del daño, pero en estados diferentes. Es importante entonces distinguir bien entre el hecho dañino actual y el hecho dañino potencial ${ }^{153}$.

Y en estricto sentido el autor tiene razón, porque es diferente una medida anticipatoria que impide el advenimiento del inicio del daño consumado, de aquella que es adoptada ante el evento en el cual el daño consumado ya inició pero no ha terminado. Así, por ejemplo, frente a la publicación de un libro que contenga hechos falsos sobre una persona, una cosa es impedir que el mismo salga al mercado -medida anticipatoria- y otra que, una vez salido, deba ser retirado -medida de cesación-. De cualquier forma, para la posición teórica que aquí se maneja, ambas figuras forman parte de lo que genéricamente se llama cesación del ilícito.

42. Posturas acerca de si la cesación del ilícito es o no una forma de reparar. La discusión acerca de si la cesación del ilícito es una forma de reparación ha sido enorme en términos doctrinarios. En efecto, como bien se afirma para el derecho internacional privado, pero resultando plenamente aplicable a nuestro estudio, "la peculiaridad del lugar de la cesación del ilícito en el marco de la responsabilidad internacional del Estado ha sido en muchas ocasiones negada, ya sea porque [la cesación del ilícito] se ha visto como un elemento de la obligación de reparar, ya sea porque se ha considerado como la simple consecuencia del respeto a la obligación primaria" ${ }^{54}$. Quienes consideran que la cesación del ilícito no es una forma de reparar es porque estiman que dicha figura opera sobre la fuente del daño, "calla su fuente", mas no supone la existencia del mismo ${ }^{155}$. Este sector

I52 C. Sintez, La sanction préventive en droit de la responsabilité civil. Contribution à la théorie de l'interprétation et de la mise en effet des normes, París, Dalloz, $20 \mathrm{I}$ I, p. I 55.

I 53 Ibíd., p. 8o.

I 54 LESAFFRE, Le règlement des différends au sein de l'OMC et le droit de la responsabilité internationale, cit., p. 2 I 8.

I 55 Ver, por ejemplo, L. ReIss, Le juge et le préjudice. Étude comparée des droits français et anglais, Presses universitaires d'Aix-Marseille, 2003, p. 352: "la reparación in natura del daño es usualmente asimilada a la supresión del ilícito. En derecho francés es mérito de Madame Rojou de Boubée el haber aclarado la distinción entre las dos nociones. Las medidas destinadas a 
de la doctrina estima que "las medidas que apuntan a la supresión del ilícito, tómense en un proceso de responsabilidad o en uno de naturaleza diferente, desembocan en la prevención del daño futuro. Respecto del daño ya causado por la situación ilícita, es evidente que la supresión de ésta no lo resarce, no compensa a la víctima, puesto que la medida no actúa sobre el daño mismo" ${ }^{156}$. En otras palabras,

... el objeto de la cesación del ilícito es el comportamiento ilícito como tal, es decir, la fuente misma de la responsabilidad. Consiste, para decirlo de alguna manera, en callar la responsabilidad en su fuente, en la medida en que ella todavía no se haya presentado. La cesación no influye sobre las consecuencias, jurídicas o materiales, del comportamiento ilícito pasado. Una solicitud de cesación puede, naturalmente, representar el primer estadio de la delimitación aproximativa del perjuicio causado por el hecho ilícito y, por lo tanto, de la definición de los derechos y de la obligación inherentes a la reparación. Aun en este caso, ella queda por fuera del campo de la reparación y de las relaciones jurídicas por ella instauradas ${ }^{157}$.

Por el contrario y de conformidad con lo dicho en la definición de daño en este escrito, esto es, por considerar precisamente que su existencia opera desde el momento mismo en que se altera el goce pacífico del derecho, estimamos que dicha figura es también reparación del daño. Hacer cesar un daño supone que este ya comenzó. Si bien es cierto esta temática produce candentes debates, es claro que aun los doctrinantes que consideran que no se puede asociar cesación del ilícito con reparación son conscientes de que, "de lega lata, la situación es confusa. [...] la Corte de Casación no parece dispuesta a distinguir de una manera general la cesación de la reparación in natura" ${ }^{58}{ }^{8}$. También en el derecho internacional, el ya citado Decaux, partidario de no calificar la cesación del ilícito como forma de reparación de daños, considera que, "insistiendo sobre el carácter específico de la obligación de cesación, el ponente la coloca 'a medio camino' entre las

hacer desaparecer la causa del daño no podrían confundirse con la reparación del daño. Si bien la noción es esencialmente de origen doctrinario en derecho francés, una medida judicial equivalente a la cesación del ilícito existe en derecho inglés: es la quia timet injunction. En los dos casos, los jueces francés e inglés buscan hacer cesar la situación que causa el daño. En efecto, ordenando medidas tendientes a la supresión de la situación ilícita, el juez tiene el objetivo de hacer cesar la situación que causa el daño, mientras que la reparación se aplica directamente sobre el daño".

I 56 F. Navia Arroyo, "La supresión del ilícito en la acción popular", en Tendencias de la responsabilidad civil en el siglo XXI, Primeras Jornadas de Derecho Privado, 22 y 23 de abril de 2008, Bogotá, Pontificia Universidad Javeriana y Biblioteca Jurídica Diké, 2008, p. 326.

I 57 Decaux, "Responsabilité et réparation”, en La responsabilité dans le système international, Colloque du Mans, cit., p. 158.

I 58 Ph. Brun, Responsabilité civile extracontractuelle, París, Lexis Nexis, 2014, p. 406. 
reglas primarias y las reglas secundarias" ${ }^{59}$. Y es que dicha confusión se origina en que no es fácil determinar si una medida de cesación del ilícito opera sobre el hecho dañino o sobre el daño, puesto que operando sobre el primero repercute inmediata e inexorablemente sobre el segundo. En la doctrina nacional el profesor Tamayo Jaramillo ubica la cesación del ilícito como primera expresión de la reparación en especie y afirma que "puede comprender desde la destrucción total de la cosa o situación, hasta la implantación de medidas tendientes a hacer desaparecer el perjuicio, corrigiendo lo hecho" ${ }^{600}$. Es por lo anterior que se puede afirmar:

... la pertenencia de la obligación de cesación a la categoría de reglas secundarias no genera duda en el presente. Como lo ha dicho M. Forteau, "la obligación de cesación del hecho ilícito pertenece indiscutiblemente hoy en día al tema de las consecuencias jurídicas que genera la responsabilidad del Estado". Ella figura en la segunda parte relativa al contenido de la responsabilidad internacional del Estado del proyecto de artículos adoptado por la CDI en 200I. Su artículo 30 dispone: "El Estado responsable del hecho internacionalmente ilícito tiene la obligación $[\ldots]$ de hacerlo cesar si continúa" ${ }^{16 r}$.

43. La presentación de la cesación del ilícito en las diferentes acciones procesales. A continuación se pretende demostrar, a partir de ejemplos jurisprudenciales, cómo la cesación del ilícito ha sido utilizada por la diversas Cortes como forma de reparación del daño.

En primer lugar, se citarán algunos pocos casos -de los innumerables que existen- de la acción de tutela, en los cuales la figura en estudio opera antes de la iniciación del daño expresado como lesión consumada del derecho. Es lo que podría ocurrir en el precitado caso en el cual se protege la vida de una persona que ha recibido amenazas ciertas de muerte ${ }^{162}$. Sin necesidad de que haya habido sentencia en la acción de tutela, como ocurre en el evento anterior, también se presenta la hipótesis en estudio cuando la Corte Constitucional impone medidas provisionales o cautelares en la misma acción de tutela, para proteger un derecho fundamental. Nótese que, siendo la acción de tutela una acción rápida con efectos inmediatos, permite sin embargo que el juez tome medidas cautelares. Ello se presenta cuando, ante la ausencia comprobada de servicios de enfermería que debe proveer una EPS a un ciudadano diagnosticado con una grave enfer-

I59 Decaux, "Responsabilité et réparation", cit., p. I 58.

i6o Tamayo Jaramillo, Tratado de la responsabilidad civil, t. 2, cit., p. 677.

i6 I LesafFre, Le règlement des différends au sein de l'omC et le droit de la responsabilité internationale, cit., p. 220.

I62 Corte Constitucional, T-525 del i 8 de septiembre de r992, M.P.: Ciro Angarita Barón, actor: Darío Antonio Mejía. 
medad, la corporación ordena como medida cautelar que la entidad "autorice el servicio de enfermería para realizar el procedimiento de cateterismo vesical intermitente, al ciudadano (xx), en la cantidad de veces al día que sea necesario, desde el momento en el cual se notifique el presente auto hasta la fecha en que esta Corporación profiera fallo definitivo en el proceso de revisión del asunto de la referencia”, evitando así la concreción de un perjuicio irremediable, consistente en el fallecimiento del ciudadano ${ }^{163}$. También puede traerse a colación el caso de un señor de la tercera edad, quien a raíz de un incidente de desacato, es obligado a cumplir una sanción correspondiente a cinco días de arresto. La Sala califica como excesiva la sanción impuesta, por tratarse de un sujeto de especial protección constitucional, "quien en virtud de su avanzada edad puede sufrir graves perjuicios a su salud e integridad física al ser internado en un establecimiento carcelario". Por consiguiente, resuelve suspender la orden de captura, mientras la Sala de Revisión decide de fondo las pretensiones expuesta por el accionante ${ }^{\mathrm{I} 64}$.

También la acción de tutela opera en los casos en los cuales se presenta daño continuado, cuando ya inició la lesión definitiva del derecho, pero dicha lesión se sigue presentando. Es el caso de una madre de cuatro niños menores de edad que se encuentra privada de la libertad y que es trasladada de la cárcel de Barranquilla a aquella de Jamundí (Valle), siendo así separada de su grupo familiar. En mérito de lo anterior, la Corte definió que, al realizar la orden de traslado, el INPEC no había valorado la situación particular de la rea, vulnerando con ello su derecho fundamental y el de sus hijos a la unidad familiar. Así pues, el juez constitucional ordenó al INPEC efectuar el traslado de la madre a Barranquilla o a otro establecimiento carcelario ubicado en un lugar cercano a donde residen sus hijos ${ }^{165}$.

En segundo lugar, en lo atinente a la acción popular, la cesación del ilícito se presenta tanto en las hipótesis en las cuales opera antes de la iniciación de la lesión definitiva, como en aquellas en las cuales ya hay inicio de dicha lesión. Son, por ejemplo, los casos donde se encuentran en juego el patrimonio público y la moral administrativa. La jurisprudencia precisó al respecto que "si se advierte la

I63 Corte Constitucional, auto 065/1 5 del 3 de marzo de 2015, M.P.: Martha Victoria Sáchica Méndez, actora: Deisy Romero García, exp. T-2.029.353.

I64 Corte Constitucional, auto 072 del I 7 de febrero de 2009, M.P.: Humberto Antonio Sierra Porto, actor: Deisy Romero García, exp. T-4.705.053.

r65 Corte Constitucional, T-374 del i I de mayo de 20 i I, M.P.: Jorge Ignacio Pretelt Chaljub, actores: Enrique Bastidas y Miryam Tapias Alandete, en representación de sus hijos menores de edad, exps. T-2.933.450 y T-2.936.858. En el mismo sentido, cfr. Corte Constitucional, T-844 del 24 de noviembre de 2009, M.P.: Jorge Ignacio Pretelt, actor: Wilson Duque Cuéllar, quien actúa en representación del niño Ken Nakashima Solarte, exp. T-2.296.o67: dicha providencia resuelve el caso de una madre cabeza de familia que es trasladada desde Armenia, donde se encuentra su hijo menor de edad, a un centro penitenciario en Cali. La corporación ordena al INPEC el traslado de la reclusa a Armenia, donde se encuentra su núcleo familiar. 
afectación del patrimonio público, el juez tiene facultades preventivas y, como consecuencia de ello, puede adoptar medidas transitorias o definitivas de protección, las cuales sólo pueden evaluarse en el caso concreto" ${ }^{166}$. Esto es lo que ocurrió con el precitado fallo en el cual, frente a una acción popular en contra de un proceso de selección que tenía por objeto la privatización de los servicios públicos de un municipio, y que ya había sido organizado, habiendo sido también fijado un precio para la oferta, el Consejo de Estado ordenó a la alcaldía y a la empresa pública que "suspendan inmediatamente el proceso de concesión de la empresa demandada, hasta tanto se adopten las medidas necesarias para tomar en cuenta los balances y los estados que reflejen la realidad financiera de la empresa y, luego, con base en los mismos, se defina el esquema de gestión empresarial que asegure la prestación eficiente del servicio público de acueducto y alcantarillado de todos los habitantes de Ibagué". En este tipo de asuntos, el juez considera que el derecho colectivo se encuentra al límite de un ataque definitivo e impide su violación inminente ordenando que se adopten las medidas apropiadas para que cese la amenaza y no se convierta por tanto en lesión definitiva. También puede citarse la sentencia del 5 de octubre de 2005 donde se ordenó la suspensión del acta de liquidación bilateral de un contrato administrativo de honorarios de un abogado ${ }^{167}$. Respecto de daños continuados en los cuales la afectación al patrimonio público ya inició pero continúa, es paradigmática la sentencia proferida el 28 de marzo de 2014 con ocasión de la grave contaminación del río Bogotá. Luego de un exhaustivo análisis de los supuestos fácticos, la Sala ampara los derechos colectivos relacionados con el agua y el goce de un ambiente sano y declara como responsables de la "catástrofe ambiental, ecológica y económico-social de la cuenca hidrográfica del río Bogotá”, por acción, a los habitantes e industrias de la cuenca y, por omisión, a la Nación. A modo de reparación del daño, la corporación ordena al Gobierno Nacional presentar un proyecto de ley de creación de la "Gerencia de la Cuenca Hidrográfica del Río Bogotá -GCH- y del Fondo Común de Cofinanciamiento -Focof-”, con el principal objetivo de lograr la cesación del ilícito ${ }^{\mathrm{I} 68}$. Se debe anotar que en estos eventos la acción popular cumple el mismo objetivo que la acción de tutela, con la única diferencia de que el marco de protección son los derechos colectivos y no los constitucionales fundamentales.

En materia de controversias contencioso ordinarias, vale la pena recordar aquí la facultad que dan las reglas de Unidroit para exigir garantías de cumplimiento al otro contratista, al permitir al acreedor que razonablemente puede

I66 C.E., Sección v, 24 de agosto de 200I, C.P.: Darío Quiñones Pinilla, actor: Procurador Provincial de Ibagué, exp. 7300 I-23-31-000-2000-I 704-0I(AP-IO0).

I67 C.E., Sección III, 5 de octubre de 2005, C.P.: Ramiro Saavedra Becerra, exp. I 588.

i 68 C.E., Sección i, 28 de marzo de 2014, C.P.: Marco Antonio Velilla Moreno, actores: Gustavo Moya Ángel y otros, exp. 25000-23-27-000-200I-90479-0I(AP). 
considerar la inejecución importante de su deudor, la posibilidad de exigir "medidas suficientes que aseguren la buena ejecución" del contrato. En otras aéreas del derecho se puede observar el auto por medio del cual se restituyó en su cargo al suspendido alcalde de Bogotá, por las sanciones disciplinarias que le impuso la Procuraduría General de la Nación. A pesar de que no había prosperado una acción de tutela en el mismo sentido, el Consejo de Estado, vía acción ordinaria de nulidad y restablecimiento del derecho, tomó la medida cautelar de urgencia de suspender las sanciones disciplinarias, lo cual significó que el alcalde fuera restituido en su cargo ${ }^{169}$.

\section{B.2. Formas "novedosas" de reparación}

44. Las diversas formas de reparación. Muchas de las formas de reparación que son hoy en día novedosas gracias al discurso de los derechos humanos y aun de otras áreas del derecho, pueden ser consideradas como reparación in natura. Así se pudo mostrar en este escrito cuando se analizaron las contribuciones nacionales e internacionales a las diversas formas de reparación diferentes de las clásicas. Sin embargo, frente a formas de reparar como la satisfacción o la rehabilitación, la discusión de si se trata de reparación in natura puede presentarse. En efecto, "la Corte ha incluido progresivamente una variedad de medidas entre las que se confunden formas de garantizar los derechos vulnerados con medidas que son propiamente de reparación. Muchas de ellas tienen un alcance amplio y se traducen en la aprobación de leyes o la ejecución de políticas de aplicación general, que persiguen mejorar la protección de los derechos fundamentales no sólo de las víctimas, sino de otras personas en condiciones similares" 170 . Esto porque la novedad que han tenido diversas expresiones de la reparación genera la polémica de hasta dónde va dicho concepto. Es así como, para presentar este acápite del escrito, se estudiará en un primer momento las reparaciones "novedosas" más usuales (B.2.a), para luego entrar a considerar la figura de la reparación transformadora (B.2.b).

\section{B.2.a. Las reparaciones "novedosas" más usuales}

45. Las reparaciones simbólicas o de satisfacción. Acorde con la definición de las distintas formas de reparación que en este texto se han estudiado, la reparación por satisfacción se encuadra dentro del marco de la reparación in natura del daño, en la cual puede adquirir múltiples expresiones. Afirma la jurisprudencia:

... la satisfacción, [es] una noción difusa que abarca principalmente la reparación simbólica. Este concepto está integrado por el reconocimiento a las víctimas,

I69 C.E., Sección II, Subsección B, I 3 de mayo de 20 I4, exp. I I 3 I-I4.

I 70 Steiner y Uribe (eds.), Convención Americana sobre Derechos Humanos, cit., p. 848. 
conmemoraciones y homenajes o las disculpas públicas entre otras medidas. La satisfacción no debe confundirse con la indemnización por daño moral o psicológico ni con las medidas de rehabilitación (incluyen los gastos derivados de la recuperación psicológica y física por las secuelas que indudablemente generan las violaciones de derechos humanos), aunque indiscutiblemente todas ellas aportan significativamente a la superación del daño. De forma más concreta, hace referencia a un número de medidas que buscan reintegrar la dignidad de la víctima cesando la violación y reconociendo el daño infligido a esta. La amplia gama de medidas que incluye la Satisfacción puede ser resumida en tres dimensiones: la obligación de modificar la legislación o las prácticas que ofendan a las víctimas y en todo caso investigar los abusos cometidos en el pasado; la ejecución de medidas que busquen el reconocimiento o aceptación de responsabilidad; y por último, las medidas necesarias para llevar a cabo la reintegración de las víctimas en la sociedad restaurándoles su dignidad, su reputación y sus derechos ${ }^{17}$.

Reconociendo que "la jurisprudencia de la Corte no ha sido del todo consistente en su formulación de medidas de satisfacción" ${ }^{172}$, se citan los siguientes ejemplos que serán de utilidad para nuestro estudio:

Más allá de cómo la Corte las catalogue, entre las medidas de satisfacción ella ha dispuesto la realización de actos simbólicos de reconocimiento de la responsabilidad internacional del Estado, la instalación de placas conmemorativas en lugares de significación, como el recinto donde una víctima permaneció detenida antes de su desaparición, la publicación de partes de la sentencia, su difusión radial en la lengua propia de la víctima y su comunidad, medidas de conmemoración y homenaje a la víctima, y creación de becas a nombre de éstas ${ }^{173}$.

A continuación se presentarán algunos ejemplos para ilustrar esta idea, que no pertenecen exclusivamente al campo de los derechos humanos y que ya han sido aceptados en nuestro medio.

Dentro del ámbito de las providencias proferidas por la Corte Constitucional, el supuesto más recurrente en que se acoge este tipo de reparación corresponde a los eventos en los que la corporación ordena al demandado ofrecer disculpas públicas por el daño ocasionado. Tal es el caso de una mujer afroamericana a quien, por su color de piel, se le negó el ingreso a las oficinas del ICETEx, instituto que debió ofrecer disculpas por escrito a la accionante ${ }^{\mathrm{I} 74}$. Esta forma

I 7 I C.E., Sección III, Sala Plena, 28 de agosto de 2014, C.P.: Ramiro Pazos Guerrero, actor: Félix Antonio Zapata González y otros, exp. 32988.

I 72 SteIner y URIBe (eds.), Convención Americana sobre Derechos Humanos, cit., 2014.

I 73 Ibíd., p. 850 .

I 74 Corte Constitucional, T-366 del 27 de junio de 2013, M.P.: Alberto Rojas Ríos, actora: Leidys 
de reparación también se ha presentado en el ámbito laboral, por ejemplo, en la sentencia T-462 de 20 IO $^{[175]}$, en la cual el juez constitucional condena al empleador a celebrar una ceremonia para ofrecer disculpas públicas a una trabajadora a quien despidió cuando se encontraba en trámite de calificación de su pérdida de capacidad laboral. Otro ejemplo, diferente de los que vienen de presentarse, corresponde al caso de una menor de edad a quien se le niega la posibilidad de continuar sus estudios en el colegio por el hecho de haber contraído matrimonio. Aparte de exigir a la institución educativa el reintegro de la alumna, la Corte ordena que se haga una presentación pedagógica de los derechos constitucionales de los menores adolescentes a los estudiantes del colegio ${ }^{176}$. Los campos de aplicación del presente actuar del juez constitucional no son limitados. Así, en el área de los derechos del medio ambiente, se debe citar la reciente sentencia del 29 de mayo de 20 I $_{5}$, en la cual la Corte Constitucional

... ordenó a la empresa Dow Química restablecer la zona de la bahía de Cartagena afectada por el vertimiento de un pesticida (Lorsban) el i9 de junio de I 989 [lo cual constituye un típico caso de restauración]. Le exigió además proferir un comunicado en un diario local en el que reconozca las fallas humanas e institucionales que condujeron al derrame del compuesto químico y ofrezca perdón público por los daños ocasionados al ecosistema de la región y a sus pobladores [lo cual constituye un típico caso de satisfacción $]^{177}$.

Siguiendo en el ámbito de la jurisdicción constitucional, existe un precedente que, a pesar de no haber sido adoptado por la mayoría, muestra cómo en un proceso de constitucionalidad se puede llegar a medidas de satisfacción. Se trató de un inusitado evento en el cual se demandó por inconstitucional -en el año 2010la ley de liberación de los esclavos de $185^{6^{\left[{ }^{17} 8\right]}}$. La Corte discutió, con base en la teoría de la revisión de la conformidad a la Carta Política de r99 I de las leyes anteriores a esta, sobre si en la liberación de los esclavos por el legislador de 1856 se había incurrido en omisión legislativa, por el hecho de solo haber reconocido derechos a los propietarios, habiendo guardado silencio respecto de la tremenda injusticia padecida por los esclavos. De haberse declarado la inconstitucionali-

Emilsen Mena Valderrama, exp. T-3779365.

I 75 Corte Constitucional, T-462 del i6 de junio de 2010, M.P.: Jorge Iván Palacio Palacio, actora: Betty Sáenz de Castro, exp. T-253662 I.

I 76 Corte Constitucional, T-853 del 2 de septiembre de 2004, M.P.: Manuel José Cepeda Espinosa, actora: Cristina Espinosa Salinas, exp. T-9043 I 4.

I 77 Corte Constitucional, Sala Sexta de Revisión, 29 de mayo de 2015, T-o8o de 201 5, M.P.: Jorge Iván Palacio Palacio, Boletín de Tutela or de la Oficina de Comunicaciones, publicado en la página web de la Corte el I. ${ }^{\circ}$ de junio de 2005.

I 78 Corte Constitucional, Sala Plena, ro de octubre de 2009, M.P.: María Victoria Calle, salvamento de voto de los magistrados Juan Carlos Henao y Luis Ernesto Vargas. 
dad de la ley, debió haberse exhortado al Congreso de la República a promover y adoptar una ley de petición de excusas por la segregación y discriminación de que fueron víctima las negritudes. En este evento se hubiera podido establecer un interesante caso de reparaciones conmemorativas, que serían una especie de las medidas de satisfacción en estudio, definidas de la siguiente manera:

En el caso de las Reparaciones conmemorativas, los proyectos específicos de gobiernos u organizaciones llaman sobre todo la atención sobre la barbarie y la humillación que implicaron opresiones pasadas; es decir, miran al pasado y se construyen sobre la percepción de las víctimas y del público en general de los datos anteriores, mas no de los daños actuales que son resultado de la opresión pasada [...] Sobre la investigación histórica también se pronuncia la declaración (Declaración de Viena y plan de acción de africanos y descendientes de africanos de 200I), argumentando que la investigación debe servir para crear un puente entre el pasado, presentando la bistoria africana de acuerdo con fuentes africanas creíbles, el presente [,] monitorizando las condiciones de vida generales de los africanos y descendientes de africanos en todo el mundo[,] y con el futuro, implementando una investigación formal para cambiar actividades, percepciones y promover el entendimiento ${ }^{179}$.

La misma lógica se encuentra en la jurisprudencia del Consejo de Estado colombiano. Es el caso de la sentencia fechada el 20 de febrero de $2008^{[180]}$ en donde se condenó por la responsabilidad frente a la desaparición, tortura y posterior muerte de dos hermanos en el municipio de Tuluá. Igual proceder se observa en la sentencia del 4 de mayo de 20 I i que, a más de contener un desarrollo doctrinario bien interesante en lo que se refiere a las diversas formas de reparar en el

179 Afro-reparaciones: Memorias de la esclavitud y fusticia Reparativa para negros, afrocolombianos y raizales, C. Mosquera Rosero-Labbé y L. C. Barcelos (eds.), Bogotá, Universidad Nacional de Colombia, Colección ces, 2007, p. I96.

I80 C.E., Sección III, 20 de febrero de 2008, C.P.: Enrique Gil Botero, exp. I6996, actor: María Delfa Castañeda, en cuya parte resolutiva, a más de reparar económicamente lucro cesante y daño emergente así como el daño moral mediante salarios mínimos, se afirmó: “4) condÉNASE a la Nación -Ministerio de Defensa, Policía Nacional- y al municipio de Tuluá, Valle del Cauca, a la reparación de la violación de los derechos humanos de los señores Omar y Henry Carmona Castañeda, para lo cual, de conformidad con la parte motiva de esta providencia, deberán adoptar las siguientes medidas de naturaleza no pecuniaria: El señor Director General de la Policía Nacional presentará públicamente, en una ceremonia en la cual estén presentes los familiares de los hermanos Cardona-demandantes en este proceso-, excusas por los hechos acaecidos entre el 27 y 3 I de enero de I995, en la población de Tuluá, relacionados con la desaparición forzada y posterior muerte de los mismos. En similar sentido, el Comando de Policía de Tuluá (Valle del Cauca), a través de su personal asignado en dichas instalaciones, diseñará e implementará un sistema de promoción y respeto por los derechos de las personas, mediante charlas en diversos barrios y centros educativos de dicha ciudad, y con entrega, de ser posible, de material didáctico, en el cual la población tenga conciencia de los derechos humanos de los cuales es titular cada individuo. La parte resolutiva de la presente sentencia, será publicada, en un lugar visible, en el Comando de Policía de Tuluá, por el término de seis (6) meses, de tal forma que toda persona que visite dicha estación, tenga la posibilidad de acceder al contenido de la misma”. 
derecho internacional, ordena a la Fiscalía General de la Nación iniciar investigaciones de cara al fallecimiento de unas personas y, al tiempo, la publicación de la sentencia en la Estación de Policía que originó los hechos ${ }^{18 \mathrm{I}}$. Similar solución se advierte en un caso de "falsos positivos" en el cual se ordena, entre otras, la publicación en varios diarios de "una nota en la que conste claramente que Juan Carlos Misat Camargo no pertenecía a ningún grupo armado ilegal y que su muerte no se produjo en desarrollo de un enfrentamiento armado, [así como la redacción por parte del Ejército] de una carta dirigida a todos y cada uno de los demandantes, la cual deberá contener una disculpa y un reconocimiento oficial de los hechos que sirven de fundamento a este fallo" ${ }^{82}$. Otra sentencia, en donde el juez exigió la reparación in natura sin equivalente pecuniario, corresponde al caso de un grupo armado que incursionó en el municipio de Morroa (Sucre), donde fueron masacradas I4 personas sin que hubiera habido intervención alguna por parte de la Armada Nacional o la Policía Nacional. Por tal actitud omisiva, el Estado (Armada y Policía) fue condenado a la realización de una ceremonia en el lugar de los hechos para pedir excusas públicas, y se ordenó asimismo la instalación de una placa conmemorativa de las víctimas ${ }^{183}$. Finalmente, se cita otro ejemplo de la referida forma de reparación, correspondiente al caso de varios soldados del Ejército Nacional que murieron por un ataque de más de doscientos guerrilleros pertenecientes a las FARC en el Departamento de Nariño. Además de la condena por los perjuicios materiales sufridos, la Sala ordenó el cumplimiento de varias medidas de reparación no pecuniarias, en aras de cumplir con la reparación integral. Así, el Consejo de Estado decretó la realización de un acto público de reconocimiento de responsabilidad, petición de disculpas y reconocimiento a la memoria de los soldados caídos ${ }^{184}$.

En sede de la Corte Interamericana de Derechos Humanos la lógica es similar. Son tan numerosos los ejemplos sobre reparación simbólica, que me limitaré a dos en los que fue condenado el Estado colombiano. Se trae a colación, por su importancia, el caso de la masacre de Mapiripán, en cuya sentencia la Corte ordena al Estado construir un monumento "apropiado y digno" para recordar la masacre, al igual que se había hecho en el caso de la masacre de Trujillo. Le exige, además, implementar "programas de educación en derechos humanos y Derecho Internacional Humanitario permanentes dentro de las fuerzas armadas

I8 8 C.E., Sección III, Sala Plena, auto de 4 de mayo de 20 i i, C.P.: Enrique Gil Botero, actor: Jorge Lino Ortiz y otros, exp. I9355.

I 82 C.E., Sección III, Subsección B, 29 de marzo de 201 2, C.P.: Danilo Rojas Betancourth, actor: José Isabel Misath y otros, exp. 2 I 380.

I 83 C.E., Sección III, Subsección C, 9 de julio de 20I4, C.P.: Enrique Gil Botero, actores: María Calixta Villalba Martinez y otros, exp. 44333.

I 84 C.E., Sección III, Subsección C, 20 de octubre de 2014 , C.P.: Jaime Orlando Santofimio Gamboa, actores: Carlos Enrique Hidalgo Vargas y otros, exp. 3 I 250. 
colombianas" ${ }^{185}$. Más recientemente la Corte Interamericana exigió a Colombia, además de la construcción de una estatua y la instalación de una placa en memoria de una masacre, que la ceremonia de inauguración fuera retransmitida por una cadena nacional de televisión ${ }^{186}$.

46. Las medidas de rehabilitación. Esta forma de reparación fue definida por el artículo 8. ${ }^{\circ}$ de la Ley 975 de 2005 como aquella que "consiste en realizar acciones tendientes a la recuperación de las víctimas que sufren traumas físicos y sicológicos como consecuencia del delito", lo cual fue precisado por el artículo 47 de la misma ley donde se afirmó que "deberá incluir la atención médica y psicológica para las víctimas o sus parientes en primer grado de consanguinidad de conformidad con el Presupuesto del Fondo para la Reparación de las Víctimas". La limitación a dicho grado de consanguinidad fue demandada ante la Corte Constitucional, que en sentencia C-370 de 2006 declaró la constitucionalidad condicionada de la norma, en el entendido de que no se excluyera como víctimas a otros familiares que hubieran sufrido daño. Se reitera que ambos artículos de la Ley 975 fueron derogados por la Ley I 448 de 20 I I, lo cual no obsta para afirmar que sus conceptos e ilustraciones sirven de referencia actual. A más de las acciones que en materia de traumas físicos y sicológicos trae la normativa nacional, se debe precisar que en la Resolución 50/I47, llamada "Van Boven" y ya referida en este escrito, se adiciona que la rehabilitación procede también para "los servicios jurídicos y sociales".

Esta forma de reparar es utilizada por nuestra jurisprudencia, sobre todo la de la Sección Tercera del Consejo de Estado, en sede de reparación directa. Es lo ocurrido en la sentencia del 25 de mayo de 20 i en la cual se condenó al Estado por la muerte y lesiones de varios soldados en la Base Militar Las Delicias por parte de las FARC, y en donde, entre otras cosas, se ordenó "proveer a las víctimas y a sus familias un tratamiento psicológico, que permita su reinserción social y la superación de las huellas de la guerra" ${ }^{187}$. Similar aconteció frente a las lesiones ocasionadas a una persona que desarrollaba labores de asistencia humanitaria en el marco de una protesta campesina contra las medidas adoptadas por el Gobierno Nacional para contrarrestar los cultivos ilícitos, quien recibió un impacto de bala por parte del ejército. En esta ocasión el Consejo de Estado ordenó a la entidad condenada que "a través de su sección de sanidad inicie la atención mé-

I 85 CIDH, I 5 de septiembre de 2005, caso de la "masacre de Mapiripán” vs. Colombia.

I 86 CIDH, I I de mayo de 2007 , caso de la "masacre de La Rochela" vs. Colombia, n. ${ }^{\circ} 27$.

I 87 C.E., Sección III, Subsección C, 25 de mayo de 20 I I, C.P.: Jaime Orlando Santofimio Gamboa, actor: José Ignacio Ibáñez y otros, exps. I 8075 y 252 I 2 . Para solo citar dos ejemplos más con la misma conclusión: 8 de junio de 20 I I, C.P.: Jaime Orlando Santofimio Gamboa, actor: Antonio Ramos Herrera y otros, exp. I9773. 
dica complementaria que el señor Castro Valencia requiere para la recuperación definitiva de su integridad física" ${ }^{188}$.

A diferencia de lo que ocurre a lo ancho de casi todo el espectro de las medidas de satisfacción, en este evento de la rehabilitación queda la duda de si en el fondo lo que se está ordenando es el pago de una reparación que en últimas es un daño emergente por el valor de lo que representan las medidas para solventar en lo posible las secuelas síquicas, jurídicas o sociales de las víctimas. Pero, como se ha dicho, en este trabajo no se está estudiando la tipología de los daños sino la forma de repararlos, y por ello bien puede el Consejo de Estado utilizar estas órdenes para garantizar la rehabilitación de las víctimas.

47. Las garantías de no repetición. Una de las consecuencias obvias de la responsabilidad civil es la de garantizar que los hechos que originaron la lesión de los derechos no volverán a tener ocurrencia. En la mencionada Resolución 56/83 de 200 I de la onu se establece en su artículo 30 que el Estado que ha incurrido en un hecho internacionalmente ilícito, tiene la obligación de "otorgar la seguridad y las garantías apropiadas de no repetición si las circunstancias lo exigen”.

$\mathrm{Al}$ igual que para las reparaciones anteriores, esta forma de reparación se puede presentar en diversas acciones procesales. Tal es el caso de un menor brutalmente asesinado por un agente de la Policía. En sede de reparación directa, el Consejo de Estado condenó a la Nación y estableció que, "comoquiera que el daño antijurídico [...] es constitutivo de una grave violación al más preciado de los Derechos Humanos -el derecho a la vida-, con apoyo en la jurisprudencia trazada por la Corporación y por la Corte Interamericana de Derechos $\mathrm{Hu}-$ manos, se dispondrán medidas de satisfacción y una garantía de no repetición, dirigidas a refrendar el principio de justicia restaurativa". Así, la Sala ordenó a la Nación, como garantía de no repetición, la realización de un plan de instrucción dirigido a todos sus funcionarios, respecto de las consecuencias, responsabilidades y sanciones en cabeza del Estado derivadas de conductas como las que dieron lugar a la formulación de la demanda, en aras de evitar que una acción de ese tipo volviera a repetirse ${ }^{189}$. También, frente al evento de la violación de una menor de edad en una estación de policía, el Consejo de Estado ordenó, en calidad de "medidas de satisfacción así como [de] garantías de no repetición con la finalidad de restablecer el núcleo esencial de los derechos fundamentales lesionados y con el propósito de que una situación como la descrita no se vuelva a repetir" ${ }^{190}$, tanto disculpas a través de medios de comunicación masiva como la publicación de la

I 88 C.E., Sección III, Subsección B, 30 de abril de 20I4, C.P.: Stella Conto Días del Castillo, actor: Jesús Ernesto Castro y otros, exp. 29.783.

I 89 C.E., Sección III, Subsección A, I7 de abril de 20I3, C.P.: Hernán Andrade Rincón, actor: Blanca S. Fonseca, exp. 36566.

I90 C.E., Sección III, Subsección C, I 5 de febrero de 20 i 2, C.P.: Olga Mélida Valle de De la Hoz, exp. 48 I 3 . 
sentencia en todas las estaciones de policía del país. Para mencionar un último ejemplo, se cita la orden dada por el Consejo de Estado al Ministerio de Educación Nacional en el sentido de expedir un manual de utilización de laboratorios de física y química, así como de adecuación de las normas técnicas de uso de los laboratorios, ante el caso del accidente con graves secuelas en la salud de una estudiante $^{\mathrm{I} 9 \mathrm{I}}$. Finalmente, ahora en el campo de la acción popular, se observa la misma lógica cuando el Consejo de Estado decide, frente a la autorización estimada ilegal de permitir la caza de micos para investigación de la vacuna sintética de la malaria, prevenir a la corporación regional del medio ambiente, para "que en el evento de volverse a emitir permiso de caza e investigación a la Fundación Instituto de Inmunología de Colombia (FIDIC), se adelante en total acatamiento del ordenamiento jurídico, en especial con sustento técnico del número y especie de la fauna a capturarse, de las condiciones de su movilización, confinamiento y repoblamiento, como de la implementación de un zoocriadero de los especímenes objeto de estudio" ${ }^{192}$.

En derecho internacional esta situación se presenta recurrentemente, y se trae a colación para ilustrar mejor el punto que ahora se estudia.

El reciente fallo de la cij en el caso LaGrand aclaró notablemente la situación. Por primera vez las garantías y la seguridad tuvieron un papel protagónico en la Corte. En el caso, Alemania había demandado que ante los reiterados incumplimientos de las misiones consulares de Estados Unidos, este país debía otorgar garantías específicas contra la repetición de las infracciones. Según los Estados Unidos las medidas de garantía de no repetición no estaban aceptadas por el derecho internacional. En su sentencia la Corte se pronuncia a favor de la posición alemana. Obliga a los Estados Unidos a dar garantías y seguridad para que en el futuro el derecho de asistencia consular sea respetado ${ }^{193}$.

48. Las reparaciones artísticas: mezcla de medidas de satisfacción y de garantías de no repetición. Muchas aproximaciones existen para lograr el objetivo de dignificar a las víctimas, como se ha visto en los ejemplos precedentes. Quisiera resaltar uno que enfoca estas reparaciones desde la perspectiva artística:

En el anterior sentido, pareciera que el aporte más significativo del arte estaría en relación con tres de los elementos anotados. En primer lugar, con la rehabi-

I9I C.E., Sección III, Subsección C, 29 de agosto de 20 I 2, C.P.: Jaime Orlando Santofimio Gamboa, actor: Mauricio Andrés López y otros, exp. 24779.

I92 C.E., Sección III, Subsección C, 26 de noviembre de 2013, C.P.: Enrique Gil Botero, actor: Ángela María Maldonado y otros, exp. AP-227-or.

I93 Ch. J. Tams, "Les obligations de l'État responsable: le lien manquant?", en Obligations multilaterales, droit impératif et responsabilité internationale des États, P-M. Dupuy (ed.), París, Pedone, 2003, p. 83 . 
litación, en donde se podría citar el uso de las técnicas terapéuticas de la arteterapia, que utiliza diferentes mecanismos artísticos como la danza, la pintura, el clown, para pacientes con traumas o problemas provenientes de conflictos psicológicos o sociales; desde este punto de vista, el arte, más que un medio de expresión estética, es un mecanismo de búsqueda y de resolución de conflictos. En segundo lugar, el arte se relaciona con las garantías de satisfacción, cuando aquel incorpora elementos de la verdad de lo ocurrido, la memoria y la dignificación de las víctimas; y en relación con las garantías de no repetición, se refiere especialmente al papel pedagógico, sensibilizador, educativo y didáctico del arte, tanto en la formación de las emociones como en la capacidad para modificar comportamientos en torno al conocimiento y respeto por los derechos humanos ${ }^{194}$.

49. Los Centros de Memoria Histórica: otra mezcla de medidas de satisfacción y de garantías de no repetición. También quisiera resaltar la importante función que los Centros de Memoria Histórica juegan en este sentido, al buscar recuperar la memoria de la lesión de los derechos, lo cual, por ejemplo, "ha permitido la digitalización de los fondos documentales sobre negros y esclavos del Archivo General de la Nación y de algunos otros archivos del país, que ahora pueden ser consultados por cualquier persona desde un computador vía Internet" ${ }^{9}$.

Este principio se enunció en el numeral i del artículo 48 de la Ley 975 de 2005 que, aunque derogado por el artículo 4I de la Ley I 592 de 20 2, fue explícito al afirmar que "[1] as medidas de satisfacción y de no repetición deberán incluir: 49. I [sic]. La verificación de los hechos y la difusión pública y completa de la verdad judicial, en la medida en que no provoque más daños innecesarios a la víctima, los testigos u otras personas, ni cree un peligro para su seguridad”. Dicha lógica está inserta en la sentencia del 26 de junio de 20 I 4 que declaró la responsabilidad del Estado por un atentado perpetrado por las farc en Medellín, en donde expresamente se ordena enviar copia de la providencia "al señor director del Centro Nacional de Memoria Histórica y al Director del Archivo General de la Nación, con el fin de que haga parte de su registro y contribuya a la construcción documental del país, que busca preservar la memoria de la violencia generada por el conflicto armado interno en Colombia y la indemnización de los bienes de las víctimas" ${ }^{196}$. Similar solución se adoptó en un caso en el cual se declaró la responsabilidad del Estado por la tortura, muerte y desaparición forzada de un ciudadano a manos de la fuerza pública, en donde también se ordenó que

i94 Y. Sierra León, "Relaciones entre el arte y los derechos humanos", Revista Derecho del Estado, Nueva Serie, n. ${ }^{\circ}$ 32, enero-junio de 20I4, Universidad Externado de Colombia, p. 8 I.

I95 Afro-reparaciones: Memorias de la Esclavitud y Zusticia Reparativa para negros, afrocolombianos y raizales, Mosquera Rosero-Labbé y Barcelos (eds.), cit., p. i9 I.

i96 C.E., Sección III, Subsección B, 26 de junio de 20 4, C.P.: Ramiro Pazos Guerrero, exp. 26 i6ı. 
"el Centro de Memoria Histórica, en cumplimiento de sus específicas funciones y de manera autónoma, elabore un documental -de mínimo veinte minutos de duración-, en el que se haga una semblanza de Luis Fernando Lalinde, reivindicando su buen nombre y dejando para la memoria de la sociedad los testimonios de lo que fueron sus realizaciones y proyecto de vida, truncado prematuramente por acciones inadmisibles en un Estado democrático de derecho"I97.

Como se observa de los ejemplos anteriores, el común denominador de las condenas mencionadas es buscar recuperar la memoria y la dignidad de la persona fallecida o en general lesionada, así como garantizar la apropiación de la verdad por el conjunto de la sociedad. Existen tantas medidas de satisfacción como creatividad puedan tener las víctimas y los operadores judiciales, pues no puede existir límite en este sentido, salvo el general ya observado, que consiste en no exigir a los responsables actos humillantes frente a sus víctimas. $Y$ este principio general tiene su sustento, puesto que mal haría una reparación en ordenar la reproducción de un discurso de odio.

50. Las garantías de no repetición, la cesación del ilícito, las medidas de rehabilitación, etc. no son excluyentes entre sí. A más de los casos citados en el parágrafo anterior, donde se observa que las sentencias permiten la acumulación de varias medidas de reparación, quiero traer a colación un interesante proceso del derecho internacional privado, en el cual se aplican tanto la cesación del ilícito como las garantías de no repetición. Se trata de un litigio entre Brasil y Canadá en donde se constató que este último país estaba dando una subvención, contraria a las normas del acuerdo SMc, a los aviones regionales que circulaban en su territorio, lo cual constituiría una barrera a la entrada en dicho comercio de otras compañías. La decisión estimó que no solo se debía retirar la norma que otorgaba la subvención (cesación del ilícito) sino, además, garantizar que no se adoptarían nuevas normas en este sentido, ya que no había elementos suficientemente claros que permitieran suponer que se garantizaría que no habría repetición de la conducta (garantías de no repetición) ${ }^{198}$.

El anterior ejemplo nos permite afirmar, así se trate de derecho comparado, que las medidas "novedosas" de reparación no son excluyentes entre sí, puesto que, en el mismo caso concreto, se puede ordenar tanto medidas de satisfacción, como de rehabilitación y de no repetición.

Lo anterior se deduce de los ya estudiados casos de este acápite del escrito, pero para ilustrarlo desde otro ámbito distinto, traigo a colación el de la condena al ICBF en virtud de una lesión cerebral sufrida por un niño a su cargo a causa de

197 C.E., Sección III, Subsección B, 27 de septiembre de 2013 , C.P.: Stella Conto Díaz del Castillo, exp. 19939 .

I98 Canadá - Mesures visant l'exportation des aéronefs civils. Demanda de Brasil al artículo 2 I:5 del Memorando de acuerdo sobre el arreglo de diferencias, WT/DS7o/RW, 9 de mayo de 2000, par. 5.10, citado en Lesaffre, Le règlement des différends au sein de l'omC et le droit de la responsabilité internationale, cit., pp. 24I-242. 
un ahogamiento parcial. Como medida de justicia restaurativa, concretamente de rehabilitación y garantías de no repetición, se ordenó al ICBF, “con el apoyo de las Universidades Nacional de Colombia, de Antioquia, y del Valle, implementar un manual técnico de seguridad obligatorio para todos los hogares comunitarios y sustitutos en el país, a efectos de que se establezcan las condiciones mínimas de protección a favor de los menores beneficiarios del servicio público de bienestar familiar" 199 .

5 I. Reparaciones colectivas. Las reparaciones colectivas son aquellas que derivan de la lesión a los derechos colectivos. Esta obviedad debe, sin embargo, permitir una precisión en el contexto del presente trabajo: la noción de derecho colectivo en el ámbito de la protección de los derechos humanos no coincide necesariamente con aquella consagrada en el artículo 88 de la Constitución de I99I, de la Ley 472 de I998 o de la Ley I437 de 20 i i, en lo atinente a las acciones populares concebidas para la protección de este tipo de derechos. La observación es pertinente porque en derechos humanos, "el derecho colectivo [...] tiene que ver con el atentado contra un derecho, interés o bien que pertenecen a la colectividad, a la comunidad, a la sociedad. El daño colectivo, por tanto, también genera un daño, solo que no es un daño contra el individuo -o al menos no directamente-, sino contra la sociedad, contra un grupo social determinado" ${ }^{200}$. Y ello no necesariamente coincide con la noción constitucional de derecho colectivo. Consciente de que esta afirmación ameritaría una investigación más profunda, opto por el momento por hacer la advertencia, puesto que, estimo, cuando en la anterior cita se habla de un interés que pertenece a "un grupo social determinado", se estaría por fuera de la concepción de derecho colectivo propia de la acción popular, que se sustenta en la protección de derechos indivisibles. Lo anterior se relaciona con el importante tema de la titularidad para reclamar por la protección de estos derechos colectivos. No considero que "cualquiera persona del pueblo", como dice el artículo roo5 del Código Civil, tenga la titularidad para reclamar por lesión de derechos colectivos a favor de un grupo social determinado en el ámbito de los derechos humanos. Son dos conceptos que, aunque en determinadas ocasiones pueden coincidir, no suponen su coincidencia automática.

De cualquier forma, el concepto en derechos humanos se encuentra anclado normativamente en Colombia. En efecto, "la ley 975 de 2005 le encargó al CNRR la realización de recomendaciones al Gobierno Nacional para la implementación de un Plan de Reparaciones Colectivas ${ }^{201}$, lo cual, desde el inicio, supuso un

I99 C.E., Sección III, Subsección C, 9 de mayo de 20 i I, C.P.: Enrique Gil Botero, actor: María Ruth Rojo Jiménez, exp. 369123.

200 López Díaz (coord.), Daño y reparación judicial en el ámbito de la Ley de fusticia y Paz, cit., p. i 6.

201 Ley 975 de 2005: "Artículo 49. El Gobierno, siguiendo las recomendaciones de la Comisión Nacional de Reparación y Reconciliación, deberá implementar un programa institucional 
importante desafío dadas las precarias experiencias de este tipo de reparación a nivel internacional e incluso por la mínima experiencia colombiana para reparar de forma individual" 202. Esta "reparación colectiva [debe realizarse] en los términos en que la ley o la naturaleza del derecho o del interés conculcado lo exija, lo cual significa que en muchos casos podrá ser necesario disponer la restitución del derecho afectado (medio ambiente, patrimonio público, salubridad, etc.), o la eliminación de la amenaza que se cierne sobre el mismo, o la indemnización correspondiente a su vulneración" ${ }^{203}$.

Se protege, pues, a la víctima colectiva que está referida en el artículo $3 .^{\circ} \mathrm{de}$ la Ley I 448 de 20 I I ${ }^{[204]}$, como ya había sido hecho por la Corte Constitucional cuando había reconocido que "la reparación tiene una dimensión doble (individual y colectiva)" ${ }^{205}$. Este concepto se liga estrechamente con la obligación de permitir conocer la verdad, por intermedio de los ya vistos Centros de Memoria Histórica o por cualquier otro medio que garantice a la sociedad el derecho a saber la verdad ante la ocurrencia de daños gravemente violatorios de los derechos humanos.

Pero no se trata de que la reparación se haga solo mediante los Centros de Memoria Histórica, pues las normas han permitido que se sienten criterios diferentes. Así,

... en concordancia con lo dispuesto en el inciso $8 .^{\circ}$ del artículo $8 .^{\circ}$ de la Ley 975 de 2005 , tratándose de comunidades afectadas por la ocurrencia de hechos de violencia masiva o sistemática, la reparación colectiva de la población afectada es el mecanismo especial e idóneo que comporta resarcimiento para todas y cada una de las víctimas de tales comunidades, además de encontrarse orientado a su reconstrucción sico-social. Los criterios formulados por la Comisión Nacional de Reparación y Reconciliación de conformidad con los incisos anteriores, serán

de reparación colectiva que comprenda acciones directamente orientadas a recuperar la institucionalidad propia del Estado Social de Derecho particularmente en las zonas más afectadas por la violencia; a recuperar y promover los derechos de los ciudadanos afectados por hechos de violencia, y a reconocer y dignificar a las víctimas de la violencia”. Este artículo fue derogado por el 4i de la Ley I 592 de 2012.

202 Sánchez Gómez (coord.), El orden desarmado. La resistencia de la Asociación de Trabajadores Campesinos del Carare (ATCC), cit., p. 436.

203 López Díaz (coord.), Daño y reparación judicial en el ámbito de la Ley de fusticia y Paz, cit., p. 246.

204 Dice el mencionado artículo: "Se consideran víctimas, para los efectos de esta ley, aquellas personas que individual o colectivamente hayan sufrido un daño por hechos ocurridos a partir del ro de enero de I 985 , como consecuencia de infracciones al Derecho Internacional Humanitario o de violaciones graves y manifiestas a las normas internacionales de Derechos Humanos, ocurridas con ocasión del conflicto armado interno".

205 Corte Constitucional, C-370 del i 8 de mayo de 2006, M.P.: Manuel José Cepeda Espinosa, Jaime Córdoba Triviño, Rodrigo Escobar Gil, Marco Gerardo Monroy Cabra, Álvaro Tafur Galvis y Clara Inés Vargas Hernández, apdo. 4.7 (en especial párrs. 4.7.2 y 4.7.3.4). 
considerados por la autoridad judicial para efectos de establecer las obligaciones de reparación en los procesos judiciales de su conocimiento ${ }^{206}$.

Dichos criterios tienen relación con:

a. Criterios referidos al acceso a la justicia, entendiendo que la efectiva garantía de dicho acceso y desarrollo serio y diligente del proceso de esclarecimiento judicial, son medidas de reparación. b. Criterios referidos a la identificación de los distintos daños sufridos por las víctimas, con el fin de favorecer la adopción ponderada de medidas de reparación que respondan, a la vez, a la noción de reparación integral. c. Criterios referidos a la prueba de dichos daños y de las pretensiones de reparación realizadas por las víctimas, con el fin de propiciar un marco justo que responda a la condición de vulnerabilidad de las víctimas, y que favorezca, de manera ajustada a las disposiciones normativas que protegen sus derechos a la verdad, la justicia y la reparación, sus posibilidades reales de probar los daños sufridos. d. Criterios referidos al vínculo entre daños sufridos y medidas de reparación, tendientes a propiciar un justo y adecuado equilibrio entre las distintas medidas que sean ordenadas por la autoridad judicial ${ }^{207}$.

Tales formas de reparación, a más de que pueden estar estrechamente vinculadas con las medidas de satisfacción ya estudiadas, con las cuales forman en ocasiones una unidad inescindible, no han sido frecuentemente utilizadas de manera sistemática por la jurisprudencia nacional. Ello no significa que no se hayan otorgado, pues habrá de hacerse una disección para encontrar su plasmación en otras formas de reparación, pero el hecho es que de un recorrido de la jurisprudencia nacional no se observan numerosos ejemplos en este sentido.

Si bien no se trata de una decisión judicial, resulta clarificador el Plan de Reparación Colectiva para la Asociación de Trabajadores Campesinos del Carare (ATCC), integrado por seis programas: “I) Construcción de una cultura de paz y dignificación de las víctimas; 2) Rehabilitación comunitaria; 3) Restitución del Trabajo Campesino y del Medio Ambiente; 4) Fortalecimiento Organizativo y de la Institucionalidad; 5) Restitución de bienes colectivos; y 6) Corresponsabilidad de otros Estados" ${ }^{208}$.

206 Art. I6 Decreto 339I de 2006, mediante el cual se reglamentó parcialmente la Ley 975 de 2005.

207 El texto completo puede consultarse en: http://www.acnur.org/t3/recursos/informacion-sobrepais-de-origen/detalle-documento-coi/recomendacion-de-criterios-de-reparacion-y-deproporcionalidad-restaurativa/

208 Ś́nchez Gómez (coord.), El orden desarmado. La resistencia de la Asociación de Trabajadores Campesinos del Carare (ATCC), cit., p. 450. 


\section{B.2.b. Las reparaciones transformadoras: ¿nueva forma de reparar perjuicios?}

52. Definición de reparación transformadora. Para definir el concepto de reparación transformadora, Rodrigo Uprimny y María Paula Saffon ${ }^{209}$ establecen que esta se contrapone a la noción de restitución. En este sentido, exponen los citados autores que, mientras la restitución tiene el objetivo de "devolver a las víctimas a la situación en la que estaban con anterioridad a los crímenes y borrar hasta donde sea posible los efectos de tales crímenes, en el segundo caso el objetivo es ir más allá de una mera restitución, buscando transformar las relaciones de subordinación y exclusión social que se encuentran en el origen del conflicto que busca ser superado y que en todo caso aparecen inicuas desde una perspectiva de justicia distributiva" ${ }^{\text {Io }}$.

En los diversos artículos citados, los autores exaltan las cualidades de la reparación transformadora y los beneficios que reporta su aplicación en nuestro país. Así pues, de cara a las violaciones masivas y protuberantes de los derechos humanos en Colombia, exponen la necesidad de apreciar la reparación no solo como una forma de justicia correctiva, sino como un modo de impulsar transformaciones democráticas en la sociedad.

La idea de los doctrinantes fue acogida por nuestra normatividad tanto en el artículo 25 de la Ley I 448 de $20 \mathrm{I} \mathrm{I}^{[2 \mathrm{II}]}$ como en el artículo $5 .{ }^{\circ}$ del Decreto 4800 de $20 \mathrm{II}^{[212]}$.

De igual manera, la noción ha trascendido a la Corte Interamericana de Derechos Humanos, en donde,

209 Ver R. Uprimny y M. P. SAfFon, El potencial transformador de las reparaciones. Propuesta de una perspectiva alternativa de reparaciones para la población desplazada en Colombia, Bogotá, Codhes, 2009; R. Uprimny y M. P. SAffon, "Uses and abuses of Transitional Justice Discourse in Colombia", en PRIO Policy Brief, n. ${ }^{\circ}$ 6, 2007; R. Uprimny y M. P. SAffon, "Reparaciones transformadoras, justicia distributiva y profundización democrática”, en Reparar en Colombia: los dilemas en contextos de conflicto, pobreza y exclusión, Bogotá, Centro Internacional para la Justicia Transicional (ICTJ) y Centro de Estudios de Derecho, Justicia y Sociedad (DeJusticia), 2009.

2 Io UpRIMNY y SAFFON, "Reparaciones transformadoras, justicia distributiva y profundización democrática", cit., p. 35 .

2 I I Cuyo tenor literal es el siguiente: "Artículo 25. Derecho a la reparación integral. Las víctimas tienen derecho a ser reparadas de manera adecuada, diferenciada, transformadora y efectiva por el daño que han sufrido como consecuencia de las violaciones de que trata el artículo $3 .^{\circ}$ de la presente Ley”.

2 I 2 Cuyo texto dice: "Enfoque transformador. Las medidas de reparación contenidas en el presente decreto buscan contribuir a la eliminación de los esquemas de discriminación y marginación que contribuyeron a la victimización, bajo el entendido que transformando dichas condiciones se evita la repetición de los hechos y se sientan las bases para la reconciliación en el país.

"El enfoque transformador orienta las acciones y medidas contenidas en el presente decreto hacia la profundización de la democracia y el fortalecimiento de las capacidades de las personas, comunidades e instituciones para su interrelación en el marco de la recuperación de la confianza ciudadana en las instituciones. Asimismo las orienta a la recuperación o reconstrucción de un proyecto de vida digno y estable de las víctimas". 
... haciéndose cargo de este problema, la Corte ha introducido, recientemente, la noción de que, en contextos de discriminación estructural, "las reparaciones deben tener una vocación transformadora de dicha situación, de tal forma que las mismas tengan un efecto no solo restitutivo, sino correctivo" (caso González y otros -'Campo algodonero'- vs. México, I 6 de diciembre de 2009, párr. 450). Ha fundamentado esta posición afirmando que "no es admisible una restitución a la misma situación estructural de violencia y discriminación”, lo que no implica, continúa la Corte, desconocer que "la naturaleza y el monto de la reparación ordenada dependen del daño ocasionado en los planos tanto material como moral". La Corte hace un interesante uso de esta noción desarrollada por UPRIMNY y SAFfon, para un caso en el que condena al Estado por no implementar las políticas que hubieran permitido prevenir la muerte de tres jóvenes secuestradas en un contexto de práctica frecuente de secuestros y muertes de mujeres y de discriminación en la protección de mujeres contra la violencia. Sin embargo, "el potencial de incorporar la noción de reparación con vocación transformadora es aún mucho mayor, pues puede implicar incorporar una perspectiva que supera la noción tradicional de restitución a la situación anterior, y puede incorporar medidas que apunten a la vigencia de los derechos económicos, sociales y culturales, a la reparación en contextos de discriminación estructural en el goce de ellos, como argumenta su autor" [cita de UPRIMnY y SAFFon en el artículo "Reparaciones transformadoras, justicia distributiva y profundización democrática, en Reparar en Colombia: los dilemas en contextos de conflicto, pobreza y exclusión, Bogotá, ICTJ y DeJusticia, 2009] ${ }^{213}$.

53. Posición personal frente a las reparaciones transformadoras. Por interesante que suene la idea anteriormente expuesta, y por loable que sea su espíritu democrático, considero que dicha noción debe ser descartada, al menos en el ámbito de la responsabilidad civil. Varios argumentos sustentan mi postura.

En primer lugar, la aplicación del principio de reparación transformadora comporta de suyo la ruptura del principio de igualdad de las víctimas. No se entendería por qué la víctima de una violación de derechos humanos protegida por la Ley I 448 de 20 I , que dicta preceptos respecto de las víctimas del conflicto armado interno en Colombia, pueda ser colocada en una situación de mejoría respecto de la situación que tenía antes del advenimiento del daño, como no ocurriría, por ejemplo, con grupos de personas de especial protección constitucional, como pueden ser aquellas de la tercera edad, los pensionados, las madres cabeza de familia, las comunidades afrodescendientes o las indígenas, etc. Se podría decir que las víctimas del conflicto armado interno en Colombia deben ser objeto de medidas de discriminación positiva -lo cual por obvias razones ha ocurrido en muchas situaciones-, pero estimo que igual debería entonces ocurrir con muchos grupos de víctimas en un país que no se caracteriza propiamente por

2 I 3 Steiner y Uribe (eds.), Convención Americana sobre Derechos Humanos, cit., p. 838. 
ser el más democrático de todos. Si dichas personas sufren un daño por fuera del marco de la aplicación de la ley, marco que -reitero- es el conflicto armado colombiano, ¿tendrán derecho a la reparación transformadora? Todo indica que no. Entonces, de dos cosas una: o el legislador optó por privilegiar a unas víctimas, lo cual sería discutible desde el punto de vista de la igualdad, o bien incurrió en una omisión legislativa que podría cuestionar la ley desde el ángulo constitucional, permitiendo solicitar que dichas medidas amplíen su espectro de protección.

En segundo lugar, aceptar la reparación transformadora es admitir abiertamente la intromisión del juez en temas de políticas públicas, con lo cual se violentan los pilares de una institución milenaria como la responsabilidad civil. Es claro que en derecho constitucional existe la discusión de hasta dónde debe intervenir el juez en políticas públicas, pero de allí a establecer como su obligación legal que lo haga, hay un gran paso. Es decir, si bien en las llamadas "megasentencias" o "sentencias estructurales" se ha discutido la intervención del juez en políticas públicas, lo que resulta claro es que en las mismas no existen condenas transformadoras en contra del Estado. La política pública sigue estando, en última instancia, radicada en cabeza de los otros poderes diferentes al judicial. No es que lo existente no se pueda cambiar, sino que toda ciencia o arte debe remitirse a los conceptos que la sustentan, so pena de perder su norte. Un contraargumento de esta posición se encuentra en el referido artículo de UpRIMNY y SAfFon, en el cual relacionan la noción de reparación transformadora con el concepto de reparación integral, que incluye a su vez la dimensión simbólica de la reparación ${ }^{214}$. No obstante, a mi juicio, la reparación transformadora desborda incluso los límites de la reparación integral. Lo anterior toda vez que, tal como se examinó previamente, cualquier forma de reparación del daño debe ordenar al deudor responder con una obligación definida directamente por el daño ocasionado. La regla de oro en este aspecto se enuncia diciendo que se repara 'el daño, todo el daño y nada más que el daño'. La reparación transformadora, en cambio, va mucho más allá de la reparación integral y atenta, de este modo, contra el principio de proporcionalidad de la condena. Es natural que una posición como la señalada de los autores citados pueda contar con muchos adeptos, ya que tiene una vocación democrática indiscutible, pero las preguntas que de ella surgen son las siguientes: ¿cuál será el límite de dicha reparación?, ¿logrará la reparación transformadora democratizar económica y socialmente el país?, ¿será ello una función propia del juez?, ¿qué ocurriría si frente a todas las masacres realizadas en Colombia y frente a todas las violaciones de los derechos humanos provenientes del conflicto armado se decretaran reparaciones transformadoras? Como vimos al inicio del presente escrito, cuando se citó el estudio de GaraY

2 I4 UPRIMNY y SAFFON, "Reparaciones transformadoras, justicia distributiva y profundización democrática”, cit., p. 46. 
y Vargas, es discutible que, aun en la hipótesis de la aplicación tradicional de la reparación, bajo el concepto de reparación integral se logre reparar todos los rubros del daño de todas las víctimas. Ni pensar qué ocurriría con la aplicación de la reparación transformadora, que es una loable idea irrealizable, que rompe con la estructura de una institución que tiene muchas formas de reparar, como se ha visto, en las cuales se transmite un discurso democrático.

En tercer lugar, debo anotar que si ya de por sí es discutible la aplicación de la reparación transformadora en los eventos en los cuales se condena al Estado, con mayor razón lo sería en los eventos en los cuales la condena fuera contra particulares. No solo se vuelve al tema de la imposibilidad real que se ha visto de que particulares asuman así sea una exigua parte de la reparación "tradicional" debida, sino que una tal exigencia iría contra otro principio que es el de enriquecimiento sin justa causa, que precisamente limita la reparación integral a la medida del daño. No se entiende por qué un particular responsable pueda ser obligado a reparar por encima del daño causado.

En cuarto lugar, se puede afirmar que, por lo pronto, en la citada sentencia del caso González y otros -'Campo algodonero'- vs. México, proferida el i6 de diciembre de 2009, la referencia que se hace en el párrafo citado al inicio de este parágrafo no es más que un obiter dictum. Revisados los I 5 puntos que conforman el "Dispone" de la parte resolutiva, no se observa ninguna medida de reparación transformadora que implique el desarrollo de una política pública concreta. En realidad, todos los dispositivos de la parte resolutiva son los tradicionales que han operado en la Corte Interamericana de Derechos Humanos, como lo son el sancionar a los responsables de la desaparición, ordenar la publicación de la sentencia en un diario, disponer la realización de un acto público en honor a la memoria de las desaparecidas, estandarizar protocolos normativos para la violencia de género, crear una base de datos de mujeres desaparecidas así como bancos genéticos, desarrollar cursos de educación y capacitación y reconocer indemnizaciones y compensaciones. No estimo entonces que dicha providencia se pueda tener como un precedente de aplicación de la figura.

En quinto lugar, los mismos comentaristas de la jurisprudencia de la Corte Interamericana dudan de la bondad real de la reparación transformadora, al afirmar:

... este desarrollo, no obstante, no está exento de riesgos. Las condiciones de injusticia estructural existentes en el Continente podrían dar lugar a un ambicioso programa de transformaciones que no puede ser impulsado por un tribunal internacional. Sin desmerecer la justificación de esta postura y la necesidad de considerar las condiciones estructurales de injusticia, es importante mantener la cautela respecto de qué está en el ámbito estricto de la decisión de un tribunal y 
qué corresponde a los Estados en la definición de sus políticas socioeconómicas $\mathrm{y}$ de inclusión social ${ }^{215}$.

A pesar de ser defensor de la función del juez como partícipe en las políticas públicas $^{216}$, considero que la noción de reparación de daños no alcanza para que por la vía jurisprudencial, de manera condenatoria y reiterada, se tracen las políticas que dependen de otras ramas del poder público, como ocurriría si se aceptan las medidas transformadoras.

En sexto y último lugar, la instauración del concepto reparación transformadora de los autores en estudio no tiene claramente definidas en la Ley I 448 de 20 I I las directivas para su aplicación. En efecto, si bien es cierto su artículo 25 establece el principio en virtud del cual "las víctimas tienen derecho a ser reparadas de manera [...] transformadora”, cuando precisa las formas concretas de reparación incluye la restitución, la indemnización, la rehabilitación, la satisfacción y las garantías de no repetición, pero no se indica cómo puede ser utilizado el concepto de reparación transformadora en cada una de ellas. Aunque en la ley el concepto de reparación transformadora se indica como uno de aquellos que ha de ser tenido en cuenta al momento de reparar a la víctima del conflicto, no queda claro si debe ser integrado en cada una de las formas de reparación, más concretamente, en la restitución, la indemnización y la rehabilitación, o si, por el contrario, estas deben ser tratadas de manera separada. Si en estas tres formas se incluyera el principio de reparación transformadora, se correría el riesgo -reitero- de hacerle cumplir a la responsabilidad civil un papel que no tiene, y que incluso prescindiendo de dicho concepto ha permitido que aun en el campo de los derechos humanos se repare íntegramente a las víctimas. $\mathrm{Si}$, como lo dice el texto del artículo $5 .^{\circ}$ del Decreto 4800 de 20 i I la reparación transformadora debe orientarse "hacia la profundización de la democracia y el fortalecimiento de las capacidades de las personas, comunidades e instituciones para su interrelación en el marco de la recuperación de la confianza ciudadana en las instituciones", se estima que con las otras formas de reparación se puede lograr dicho objetivo, sin que ello implique transformación radical favorable de las condiciones económicas y sociales de las víctimas. Las formas de reparación reseñadas en este estudio permiten, con una buena dosis de creatividad judicial, tratar con dignidad a las víctimas de daños.

2 I 5 Steiner y Uribe (eds.), Convención Americana sobre Derechos Humanos, cit., p. 838.

2 I6 Ver mi escrito "El juez constitucional: un actor de las políticas públicas", Revista de Economía Institucional, vol. I 5, n. ${ }^{\circ}$ 29, Universidad Externado de Colombia, junio-diciembre de 20 13, pp. 67-IO2. 


\section{Conclusión}

A guisa de conclusión me permito insistir en algunos puntos que considero pueden ser de utilidad para continuar con la discusión de este importante tema del derecho.

A. Las formas de reparar los daños no son exclusivas de una acción contencioso administrativa, ordinaria o constitucional. Como se pudo observar en los múltiples ejemplos citados, las diversas formas de reparación deben aplicarse en todos los procesos contra el Estado y contra los particulares. No tiene ningún sentido considerar que las acciones judiciales inciden en la forma de reparar, puesto que es más bien dicha forma la que debe ser determinada por el daño sufrido, con independencia de la acción en la cual se reclame la lesión del derecho. Lo anterior significa que es el daño lo que indica la acción y no lo inverso, ya que considerar que, por ejemplo, no cabe la petición de excusas en un contencioso laboral, no tiene sustento desde un punto de vista sustancial. Se vieron ejemplos en los cuales también en fallos de tutela se ordenaba la petición de excusas, lo cual puede ampliarse a lo contencioso laboral, a toda acción donde esté de por medio la nulidad de un acto administrativo, así como también a los procesos entre particulares. Es decir, en cualquier acción judicial deben caber las formas no excluyentes de reparación, con lo cual se permite acumular en un mismo caso, verbigracia, indemnización pecuniaria, indemnización in natura, satisfacción, rehabilitación, etc.

B. El porvenir y las ventajas de una reparación unificada de daños. Si se llegara a la lógica que aquí se plantea, esto es, la consistente en aplicar las mismas reglas sustanciales de reparación de daños en todas las acciones judiciales, a más de garantizarse de manera amplia la regla de la reparación integral, se lograría que tanto los litigantes como los jueces tuvieran el hábito de no dejarse encasillar por el petitum de determinada acción al momento de resolver un caso. Tanto unos como otros debieran tener claro que, en primer término, allí donde hay daño, hay acción, y que lo secundario es acomodarse en una u otra acción procesal determinada. Busca entonces este escrito incitar a los diversos operadores jurídicos para hacer avanzar la reparación de daños, recordando que el primer eslabón de la cadena que culmina en la jurisprudencia, lo constituye el litigante.

C. El nivel de evolución del daño determinará la forma de su reparación. Según se ha visto, en el presente trabajo se encuentra subyacente la idea de que la expresión del daño puede corresponder a tres diferentes circunstancias. En primer lugar, aquella en la que el daño se presenta durante la alteración del goce pacífico del derecho, sin que se haya iniciado la lesión definitiva del mismo. En segundo lugar, aquella en la cual la lesión definitiva del derecho ya inició, pero no ha terminado. En último lugar, aquella en la que la lesión del derecho se consumó totalmente. Respecto de las primeras dos formas opera la cesación del ilícito, bajo la analizada figura de anticipación o de cesación, que impide que 
la lesión definitiva se cristalice. Estas dos hipótesis no excluyen que se hayan podido generar daños consumados diferentes, como sería el caso de una persona a la que se protege en su vida pero que en el entretanto tuvo que sufragar gastos para resguardarse de la amenaza. La segunda hipótesis, por definición, tiene tanto de cesación del ilícito como de reparación clásica frente a la lesión ya consumada del derecho. Es por ello que cuando se presenta la situación, el sistema jurídico debe proteger tanto frente a la continuación de la lesión definitiva como frente a la parte del daño que ya se consumó definitivamente. Por el contrario, cuando se trata de la tercera forma de presentarse el daño, ya no habrá medidas de cesación, pero sí todas las demás formas de reparación que se han estudiado.

D. La cuasi exclusiva utilización solo en la Sección Tercera del Consejo de Estado y en la Corte Constitucional de medidas de reparación diferentes a las clásicas. Como se advirtió al inicio de este escrito, uno de los problemas que impiden una mayor utilización de todas las formas de reparación que se han estudiado en el presente trabajo, es que son muy pocos los operadores judiciales que las utilizan en nuestro país. Todo pareciera indicar que la Sección Primera, la Segunda, la Cuarta y la Quinta del Consejo de Estado, no tuvieran mucho que ver con la teoría del daño y más exactamente con las diferentes posibilidades para repararlo, bajo el equívoco de que en materia de acciones de nulidad y restablecimiento del derecho dicho análisis es sumamente escueto y limitado a las fórmulas tradicionales, sin que se busque el cambio que en este escrito se pide. Remito a todo lo dicho sobre el medio de defensa de nulidad y restablecimiento del derecho.

E. La utilización exclusiva de las "nuevas" formas de reparación para los eventos de masivas y sistemáticas violaciones a los derechos bumanos debe superarse. Sin querer desconocer la suma importancia que tiene una completa protección de los derechos humanos desde el ámbito de la reparación, sí se pretende llamar la atención en el sentido de que la protección que en esta área de la vida social se presenta, debería ser ampliada a muchas otras, para que la función reparadora se inmiscuya en todos los ámbitos sociales. Se piensa, por ejemplo, en la protección de la propiedad intelectual, en la protección a la honra, en la protección de la libertad de empresa, y un largo etcétera.

F. La reparación transformadora no debe admitirse como forma de reparación. $\mathrm{Si}$ bien se entiende la loable intención de incluir un concepto novedoso en materia de responsabilidad civil, se estima que su aceptación genera más riesgos que ventajas. Es decir, con el mismo no solo se altera por completo la lógica milenaria de la responsabilidad civil, sino que se convierte al juez en un ilegítimo dispensador de políticas públicas que lleva a la ruptura del principio de igualdad de las víctimas y que, por lo demás, conduce a que las innumerables sentencias condenatorias sean de imposible cumplimiento. Podría así el juez estar tentado a manejar un "populismo jurídico" en donde determine el futuro económico del país, lo cual estimo no es conveniente para una democracia. 


\section{Bibliografía}

AA. vv., Código de Procedimiento y de lo Contencioso Administrativo. Ley I437 de 20 I I. Comentado y Concordado, J. L. Benavides (ed.), Bogotá, Universidad Externado de Colombia, $20{ }_{3}$.

Bacache-Gibeili, M., Droit civil, t. v, Les obligations. La responsabilité civile extracontractuelle, París, Economica, 2007.

Barros Bourie, E., Tratado de responsabilidad extracontractual, Santiago, Jurídica de Chile, 2008.

Baudouin, J.-L. y P. Deslauriers, La responsabilité civile, 6. a ed., Quebec, Yvon Blais, 2003.

Bejarano, R., Procesos declarativos, ejecutivos y arbitrales, 5. ${ }^{a}$ ed., Bogotá, Temis, 2 OII.

Bermúdez, K. et al., Acciones de grupo en materia laboral, Bogotá, Universidad Externado de Colombia, Centro de Investigaciones Laborales, 2013.

Bцoch, C., La cessation de l'illicite. Recherche sur une fonction inconnue en responsabilité civile extracontractuelle, tesis, Université Paul Cézanne-Aix-Marseille III, sustentada el 22 de noviembre de 2006, no publicada.

Boskovic, O., La réparation du préjudice en droit international privé, París, LGDJ, BDP, t. 407, 2003.

Boutonnet, M., Le principe de précaution en droit de la responsabilité civile, París, LGDJ, BDP, t. 444, 2005.

Brun, P., Responsabilité civile extracontractuelle, París, Lexis Nexis, 20 I4.

CADiEt, L., "Les métamorphoses du préjudice", en Les métamorphoses de la responsabilité, Colloque commun aux Facultés de droit de l'Université de Montréal, de l'Université catholique de Nimègue et de l'Université de Poitiers, Sixièmes Journées René Savatier, Poitiers, I 5 y i6 de mayo de 1997, París, PUF, I 997 .

Carbonnier, J., Droit civil. Les biens. Les obligations, vol. 2, París, puf, coll. Quadrige, 2004 . 
Carrillo, A.J., "Justice in context: The relevance of interamerican human rights law and practice to repairing the past”, en P. De Greiff (ed.), The Handbook of Reparations, Oxford University Press, 2006.

Chapus, R., Droit administratif général, t. I, I 5. ${ }^{\text {a }}$ ed., París, Montchrestien, 200 I.

Comisión Colombiana de Juristas, Principios internacionales sobre impunidad y reparaciones: compilación de documentos de la Organización de las Naciones Unidas, [en línea], Bogotá, 2007, disponible en: http://www.coljuristas.org/documentos/libros_e_informes/principios_sobre_impunidad_y_reparaciones. pdf [consultado el 2 de mayo de 2015].

Comisión Nacional de Reparación y Reconciliación, Recomendación de criterios de reparación y de proporcionalidad restaurativa: artículo 52.6 ley 975 de 2005, artículo I 6 decreto 339 I de 2006, [en línea], Bogotá, 2007, disponible en: http://www.acnur.org/t3/recursos/informacion-sobre-pais-de-origen/ detalle-documento-coi/recomendacion-de-criterios-de-reparacion-y-deproporcionalidad-restaurativa/ [consultado el 2 de mayo de 2015].

Consejo de Estado, Las sentencias de unificación jurisprudencial y el mecanismo de extensión de la jurisprudencia, Bogotá, Imprenta Nacional, 20 I4.

Consejo de Estado, Sección Tercera, Unificación jurisprudencial. Perjuicios inmateriales. Perjuicio moral, perjuicios derivados de la violación de bienes constitucionales y convencionales, daño a la salud, Bogotá, Imprenta Nacional, 2014.

Cormier, C., Le préjudice en droit administratif français. Étude sur la responsabilité extra-contractuelle des personnes publiques, París, LGDJ, BDP, t. 228, 2002.

Crawford, J., Los artículos de la Comisión de Derecho Internacional sobre la Responsabilidad Internacional del Estado, Madrid, Dykinson, 2004.

Crawford, J., Les articles de la C.D.I. sur la responsabilité de l'État, París, Pedone, 2003. En inglés: The International Law Commission's Articles on State Responsability. Introduction, Text and Commentaries, Cambridge University Press, 2002.

De Cupis, A., El daño. Teoría general de la responsabilidad civil, 2. ${ }^{\text {a }}$ ed., Barcelona, Bosch, I975.

De Greiff, P. (ed.), The Handbook of Reparations, Oxford University Press, 2006. 
Decaux, E. "Responsabilité et réparation", en La responsabilité dans le système international, Colloque du Mans, Société française pour le droit international, París, Pedone, i99 I.

Diccionario de la Lengua Española, 2 r. ${ }^{a}$ ed., Real Academia Española, Madrid, Talleres Gráficos Peñalara, I992.

Diccionario Vox esencial de la lengua española. Sinónimos y antónimos, Barcelona, Bibliograf, I995.

Dominice, C., "La réparation non contentieuse", en La responsabilité dans le système international, Colloque du Mans, Société française pour le droit international, París, Pedone, r99.

Expósito Vélez, J. C., "El Nuevo Código de Procedimiento Administrativo y de lo Contencioso Administrativo (Ley r.437 de 2.0 I I)", Revista Digital de Derecho Administrativo n. ${ }^{\circ}$ 6, Universidad Externado de Colombia, julio-diciembre de 20 I , pp. $25-45$.

Gallón Giraldo, G. y M. Reed Hurtado (eds.), Principios internacionales sobre impunidad y reparaciones, Bogotá, Comisión Colombia de Juristas, 2007.

Garay Salamanca, L. J. y F. Vargas Valencia, Memoria y reparación: elementos para una justicia transicional pro víctima, Bogotá, Universidad Externado de Colombia, 2012.

García de Enterría, E. y T.-R. Fernández, Curso de derecho administrativo, t. II, 5. ${ }^{\mathrm{a}}$ ed., Madrid, Civitas, I 998.

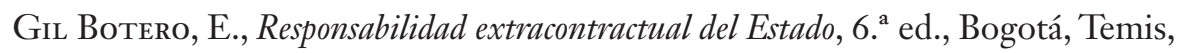
2013 .

Gil Botero, E., Tesauro de responsabilidad extracontractual del Estado, Bogotá, Temis, 2013 .

Girard, B., Responsabilité civile extracontractuelle et droits fondamentaux, París, LGDJ, BDP, t. 562, 2015 .

González Pérez, J., Responsabilidad patrimonial de las administraciones públicas, Madrid, Civitas, 1996.

Guematcha, E., Les commissions vérité et les violations des droits de l'bomme et du droit international humanitaire, París, Pedone, 2014. 
Henao Pérez, J. C., "El juez constitucional: un actor de las políticas públicas”, Revista de Economía Institucional, vol. I 5, n. ${ }^{\circ}$ 29, Universidad Externado de Colombia, junio-diciembre de 2013, pp. 67-102.

Henao Pérez, J. C., "De las distintas formas de concebir la tipología de perjuicios", en Responsabilidad civil, derecho de seguros y filosofía del derecho. Homenaje al profesor Javier Tamayo Jaramillo, t. I, Bogotá, Diké, 20 I I, pp. I39-ı67.

Henao Pérez, J. C., "De tal derecho lesionado, tal acción”, en V fornadas de Derecho Constitucional y Derecho Administrativo, Bogotá, Universidad Externado de Colombia, 2005, pp. 486-54I.

Henao Pérez, J. C., El daño. Análisis comparativo de la responsabilidad extracontractual del Estado en derecho colombiano y francés, Bogotá, Universidad Externado de Colombia, I998.

Henao Pérez, J. C., Le dommage. Analyse à partir de la responsabilité civile extracontractuelle de l'État en droit colombien et en droit français, tesis, Universidad de París 2 Panthéon-Assas, sustentada el 27 de noviembre de 2007.

Henao Pérez, J. C., "La acción de tutela y la responsabilidad extracontractual del Estado", en Homenaje a Fernando Hinestrosa. Treinta años de Rectorado. Liber Amicorum. Estudios y temas, Bogotá, Universidad Externado de Colombia, I993.

Hinestrosa, F., "Los Principios de unidroit: una nueva lingua franca", en Principios sobre los contratos comerciales internacionales, Bogotá, Ministerio de Justicia, I997.

Hinestrosa, F., Tratado de Obligaciones. Concepto, estructura, vicisitudes, t. I, Bogotá, Universidad Externado de Colombia, 2002.

Jacquemet-Gauché, A., La responsabilité de la puissance publique en France et en Allemagne, París, LGDJ, 2013.

JoAnnès, J-M., Le préjudice immateriel dans le contentieux de la responsabilité extracontractuelle de la puissance publique, tesis, Universidad de París 2, sustentada el 6 de abril de i998, no publicada.

Kolliopoulos, A., La Commission d'Indemnisation des Nations Unies et le Droit de la Responsabilité Internationale, París, LGDJ, $200 \mathrm{I}$. 
Котегсн Кнатів, M., La reparación del daño como mecanismo de tutela de la persona.

Del daño a la salud a los nuevos daños extrapatrimoniales, París, Universidad Externado de Colombia, 20 I 2.

Lessaffre, H., Le règlement des différends au sein de l'OMC et le droit de la responsabilité internationale, París, LGDJ, 2007.

López Díaz, C. (coord.), Daño y reparación judicial en el ámbito de la Ley de Fusticia y Paz, Bogotá, grz, Fiscalía General de la Nación, Embajada de la República Federal de Alemania, 20 Io.

López Medina, D. E. y A. L. SÁnchez Mejía, "La armonización del derecho internacional de los derechos humanos con el derecho penal colombiano", en International Law: Revista Colombiana de Derecho Internacional n. ${ }^{\circ}$ I 2 , Pontificia Universidad Javeriana, enero-junio de 2008, pp. 3 I 7-35 I.

Mazeaud, H. y L., y F. Chabas, Leçons de droit civil, Introduction à l'étude du droit,

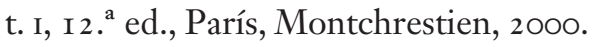

Mosquera Rosero-Labbé, C. y L. C. Barcelos (eds.), Afro-reparaciones: Memorias de la esclavitud y fusticia Reparativa para negros, afrocolombianos y raizales, Bogotá, Universidad Nacional de Colombia, Colección ces, 2007.

Organización de Naciones Unidas, Recueil des sentences arbitrales, vol. xx, I990.

Navia Arroyo, F., “La supresión del ilícito en la acción popular”, en Tendencias de la responsabilidad civil en el siglo XXI, Primeras Jornadas de Derecho Privado, 22 y 23 de abril de 2008, Bogotá, Pontificia Universidad Javeriana y Biblioteca Jurídica Diké, 2008.

Neto, X. T. de M., Dano moral coletivo, Sao Paulo, LTr, 2004.

Pierre, P. y F. Leduc, La réparation intégrale en Europe. Études comparatives des droits nationaux, Bruselas, Larcier, $20 \mathrm{I} 2$.

Plessix, B., L'utilisation du droit civil dans l'élaboration du droit administratif, París, Panthéon-Assas, 2003.

ReIss, L., Le juge et le préjudice. Étude comparée des droits français et anglais, Presses universitaires d'Aix-Marseille, 2003.

Rengifo García, E., "Valoración de perjuicios en la infracción de las patentes", artículo aún no publicado, generosamente facilitado por el autor. 
Restrepo Rodríguez, T., "El remedio preventivo en la responsabilidad civil", Revista de Derecho Privado n. ${ }^{\circ}$ I4, Universidad Externado de Colombia, enero-junio de 2008, pp. 2 I9-238.

Restrepo Saldarriaga, E., "El desplazado como paria. La garantía de los derechos a la verdad, la justicia y la reparación de las víctimas del delito de desplazamiento forzado en Colombia", en Más allá del desplazamiento. Políticas, derechos y superación del desplazamiento forzado en Colombia, C. RodRíGuez Garavito (ed.), Bogotá, Universidad de los Andes, Asdi, Embajada de Suecia Y UNHCR-ACNUR, 2010.

Roujou de Boubée, M.-E., Essai sur la notion de réparation, París, LGDJ, вDp, t. XCCCV, I974.

Rueda, I., Incidences des règles d'Unidroit sur le droit des contrats en Europe, París, LGDJ, BDP, t. 559, 2015.

Ruiz Orejuela, W., Responsabilidad del Estado y sus regímenes, Bogotá, Ecoe Ediciones, 2010.

SaAvedra Becerra, R., La responsabilidad extracontractual de la administración pública, Bogotá, Grupo Editorial Ibáñez, 20 I I .

Sánchez Gómez, G. (coord.), El orden desarmado. La resistencia de la Asociación de Trabajadores Campesinos del Carare (ATCC), Informe del Grupo de Memoria Histórica, Bogotá, Taurus y Fundación Semana, 20 i I.

Santofimio Gamboa, J. O., "Panorama general del derecho administrativo en Colombia", en El derecho administrativo iberoamericano, Granada, 2005.

Sierra León, Y., "Relaciones entre el arte y los derechos humanos", Revista Derecho del Estado, Nueva Serie, n. ${ }^{\circ}$ 32, Universidad Externado de Colombia, enero-junio de 20I4, pp. 77-Ioo.

Sintez, C., La sanction préventive en droit de la responsabilité civil. Contribution à la théorie de l'interprétation et de la mise en effet des normes, París, Dalloz, 20 I I.

Steiner, C. y P. Uribe (eds.), Convención Americana sobre Derechos Humanos, Bogotá, Editorial Temis y Konrad Adenauer Stiftung, 2014.

Stoppioni, E., La réparation dans le contentieux international de l'investissement. Contribution à l'étude de la resititutio in integrum, París, Pedone, 20 I4. 
Tamayo Jaramillo, J., Tratado de la responsabilidad civil, t. 2, Bogotá, Legis, 2007.

TAms, C. J., "Les obligations de l'État responsable: le lien manquant?”, en Obligations multilaterales, droit impératif et responsabilité internationale des États, P-M Dupuy (ed.), París, Pedone, 2003.

Travard, J., La victime et l'évolution de la responsabilité administrative extracontractuelle, París, Mare\&Martin, 2013.

Uprimny, R. y M. P. Saffon, El potencial transformador de las reparaciones. Propuesta de una perspectiva alternativa de reparaciones para la población desplazada en Colombia, Bogotá, Codhes, 2009.

UpRIMny, R. y M. P. SAFfon, "Reparaciones transformadoras, justicia distributiva y profundización democrática", en Reparar en Colombia: los dilemas en contextos de conflicto, pobreza y exclusión, Bogotá, Centro Internacional para la Justicia Transicional (ICTJ) y Centro de Estudios de Derecho, Justicia y Sociedad (DeJusticia), 2009.

Uprimny, R. y M. P. SAfFon, "Uses and abuses of Transitional Justice Discourse in Colombia", en PRIO Policy Brief n. ${ }^{\circ}$ 6, 2007.

Van Gerven, W.; J. Lever y P. Larouche, Cases, Materials and Text on National, Supranational and International Tort Law, Oxford y Portland, Hart Publishing, 2000 .

Velásquez Posada, O., Responsabilidad civil extracontractual, Bogotá, Universidad de la Sabana y Temis, 2009.

Zannoni, E., El daño en la responsabilidad civil, Buenos Aires, Astrea, I982.

\section{Normatividad}

\section{Normatividad internacional}

Convención Americana sobre Derechos Humanos (Pacto de San José).

Decisión Andina 486 de 2000.

Estatuto de Roma de la Corte Penal Internacional.

Resolución 56/83 de 200 I de la Organización de las Naciones Unidas. 
Resolución 60/147 de 2005 de la Organización de las Naciones Unidas.

Principios UNIDROIT sobre los contratos comerciales internacionales.

\section{Normatividad nacional}

Decreto 259I de I99I.

Decreto 339i de 2006.

Decreto 4800 de 20 I I.

Ley 44 de 1993.

Ley 975 de 2005 .

Ley I 448 de 20 I I.

Ley I 592 de 2012.

\section{Jurisprudencia}

\section{Consejo de Estado}

Sala Plena

28 de julio de I996, exp. S-638.

25 de agosto de 1998 , exp. IJ-OOl.

8 de septiembre de 1998, exp. IJ-oo2.

5 de noviembre de 2013, exp. AP-25000-23-25-000-2005-00662-03.

\section{Sección Primera}

7 de octubre de 1999, exp. 5437 .

I7 de agosto de 2000, exp. 6042. 
9 de noviembre de 2000, exp. $5^{808 .}$

4 de agosto de 2005 , exp. 8I6.

I. ${ }^{\circ}$ de diciembre de 2005, exp. 25000-23-26-000-2004-00098-or.

6 de septiembre de 20I3, exp. 8800I-23-3 I-000-20I I-00009-o I(AP).

28 de marzo de 20I4, exp. 25000-23-27-000-200I-90479-OI(AP).

\section{Sección Segunda}

28 de septiembre de 2000, exp. AP-I 7 .

I6 de mayo de 2002, exp. I659-or.

I4 de septiembre de 2004, exp. NIJ-683.

I9 de febrero de 2004, exp. 24027.

I9 de mayo de 20 I I, exp. 2 I 57-05.

28 de noviembre de 2012 , exp. I734-I I.

I 2 de abril de 20I4, exp. 0728-I 2.

\section{Sección Tercera}

27 de marzo de 1992 , exp. 6885 .

8 de mayo de i995, exp. 8i I 8.

I3 de diciembre de 1995, exp. Io677.

I9 de abril de 200I, exp. 195 I 7 .

20 de septiembre de 200 I, exp. AP-I 25.

3I de mayo de 2002, exp. AP-300.

29 de enero de 2004, exp. 18273. 
I 5 de abril de 2004, exp. AP-2 I 36.

5 de octubre de 2005 , exp. I 588.

8 de marzo de 2007 , exp. I642 I.

I I de agosto de 2010 , exp. I 8499.

6 de abril de 20 I , exp. 2 I653.

Subsección C, 9 de mayo de 201 I, exp. 3691 23.

23 de febrero de 2012 , exp. 24.655 .

23 de agosto de 2012 , exp. 24392.

Subsección B, 30 de enero de 2013 , exp. 22325.

Subsección C, 6 de marzo de 20I3, exp. AP-I300I233 I00020010005 I o I.

Subsección A, 2 de abril de 2013, exp. 26427.

Subsección A, I 7 de abril de 20I3, exp. 36566.

Subsección B, 30 de octubre de 2013, exp. 27 I95.

Subsección B, 20 de febrero de 20I4, exp.AP-7600I-23-3 I-000-2003-00002-0I.

Subsección C, 26 de marzo de 20I4, exp. 2874I.

Subsección A, 9 de abril de 20I4, exp. 288 I I.

Subsección A, I I de junio de 2014, exp. 26702.

Subsección B, 26 de junio de 20I4, exp. 26r6I.

Sala Plena, 28 de agosto de 20 I4, exp. 32988.

\section{Sección Cuarta}

I 8 de marzo de 2004, exp. I375I. 


\section{Sección Quinta}

24 de agosto de 200I, exp. 7300I-23-3 I-000-2000-I 704-or(AP-IO0).

9 de noviembre de 200 , exp. AP-I94.

\section{Corte Constitucional}

Sala Plena, i4 de abril de i999, exps. acumulados D-2 I 76, D-2 I 78 y D-2 I 96.

Sala Plena, 8 de junio de 2004, exp. D-4939.

Sala Plena, Io de octubre de 2009, salvamento de voto de los magistrados Juan Carlos Henao y Luis Ernesto Vargas.

C-I 49 de I993.

C-333 de 1996.

C-892 de 2001 .

C-922 de 2001 .

C-228 de 2002 .

C-9i6 de 2002.

C-53 I de 2006.

C-37o de 2006.

C-333 de 20 Io.

C-7I 5 de 2012.

C-258 de 2013 .

C-I8o de 2014.

SU-I I 50 de 2000.

T-428 de I992. 
T-525 de 1992.

T-397 de 2004.

T-853 de 2004 .

T-9i 7 de 2006.

T-085 de 2009.

T-844 de 2009 .

T-462 de 2010.

T-629 de 2010.

T-374 de $201 \mathrm{I}$.

T-606 de 20 I I.

T-366 de 2013.

T-222 de 2014.

T-65o de 2014.

T-o8o de 2015.

T-I3 I de 2015 .

T-239 de 2015.

Auto 072 de 2009.

Auto 065 de 2015 .

Auto A-I 80 de 2015.

Tribunales internacionales

CIDH, Caso "Niños de la calle" (Caso Villagrán Morales y otros c/ Guatemala), sentencia de 26 de mayo de $200 \mathrm{I}$. 
CIDH, I 5 de septiembre de 2005, Caso de la "masacre de Mapiripán" vs. Colombia.

CIDH, Caso de la "masacre de La Rochela" vs. Colombia, I I de mayo de 2007, n. ${ }^{\circ} 277$.

Corte Permanente de Justicia Internacional (Permanent Court of International Justice), Caso de la fábrica en Chorzow, Alemania vs. Polonia, I 922. 